\title{
Schoolverlaters tussen onderwijs en arbeidsmarkt 2009
}

Citation for published version (APA):

Meng, C. M., \& Ramaekers, G. W. M. (2010). Schoolverlaters tussen onderwijs en arbeidsmarkt 2009. Researchcentrum voor Onderwijs en Arbeidsmarkt, Faculteit der Economische Wetenschappen. ROA Reports No. 7 https://doi.org/10.26481/umarep.2010007

Document status and date:

Published: 01/01/2010

DOI:

10.26481/umarep.2010007

Document Version:

Publisher's PDF, also known as Version of record

\section{Please check the document version of this publication:}

- A submitted manuscript is the version of the article upon submission and before peer-review. There can be important differences between the submitted version and the official published version of record.

People interested in the research are advised to contact the author for the final version of the publication, or visit the DOI to the publisher's website.

- The final author version and the galley proof are versions of the publication after peer review.

- The final published version features the final layout of the paper including the volume, issue and page numbers.

Link to publication

\footnotetext{
General rights rights.

- You may freely distribute the URL identifying the publication in the public portal. please follow below link for the End User Agreement:

www.umlib.nl/taverne-license

Take down policy

If you believe that this document breaches copyright please contact us at:

repository@maastrichtuniversity.nl

providing details and we will investigate your claim.
}

Copyright and moral rights for the publications made accessible in the public portal are retained by the authors and/or other copyright owners and it is a condition of accessing publications that users recognise and abide by the legal requirements associated with these

- Users may download and print one copy of any publication from the public portal for the purpose of private study or research.

- You may not further distribute the material or use it for any profit-making activity or commercial gain

If the publication is distributed under the terms of Article $25 \mathrm{fa}$ of the Dutch Copyright Act, indicated by the "Taverne" license above, 


\section{Schoolverlaters tussen onderwijs en arbeidsmarkt 2009}

ROA-R-2010/7

Researchcentrum voor Onderwijs en Arbeidsmarkt Maastricht University

School of Business and Economics

Maastricht, juni 2010 


\section{Colofon}

(C) Researchcentrum voor Onderwijs en Arbeidsmarkt (ROA). Niets uit deze uitgave mag op enige manier worden verveelvoudigd zonder voorafgaande schriftelijke toestemming van de directeur van het ROA.

\section{Researchcentrum voor Onderwijs en Arbeidsmarkt}

Maastricht University

School of Business and Economics

Vormgeving

ROA secretariaat, Maastricht

\section{Verkoop}

Researchcentrum voor Onderwijs en Arbeidsmarkt email: secretary-roa-sbe@maastrichtuniversity.nl website: www.roa.nl

ISBN: 978-90-532I-488-6

juni 2010 
Inhoud

Voorwoord

Samenvatting

IX

1 Kwaliteit van schoolverlaters 1

2 Kwalificatie 5

$\begin{array}{llr}3 & \text { Selectie } & 13\end{array}$

$\begin{array}{lll}4 & \text { Kwalificerende vervolgtrajecten } & 21\end{array}$

5 Intrede op de arbeidsmarkt 31

$\begin{array}{lll}5.1 \text { Allocatie } & 31\end{array}$

$\begin{array}{lll}5.2 & \text { Extern rendement } & 40\end{array}$

6 Effect van de conjuncturele malaise $\quad 51$

$\begin{array}{ll}\text { Literatuur } & 53\end{array}$

Bijlage 1: Enkele centrale begrippen $\quad 55$

Bijlage 2: Kernindicatoren 1998-2009 57

Statistische Bijlage $\quad 59$

Tabellen naar opleidingssector 


\section{Voorwoord}

Wat vinden gediplomeerde schoolverlaters van hun opleiding en wat gaan ze na hun opleiding doen? Hoe is de aansluiting met het vervolgonderwijs? En als ze naar de arbeidsmarkt gaan, hoe snel krijgen ze dan werk? En sluit dat werk dan ook aan op de gevolgde opleiding? Hoe tevreden zijn werkende schoolverlaters met hun functie en hoe schatten zij hun carrièreperspectieven in?

Sinds 199I voert het Researchcentrum voor Onderwijs en Arbeidsmarkt (ROA) van Maastricht University in samenwerking met DESAN Research Solutions enkele grootschalige onderzoeken uit onder recente schoolverlaters en pas afgestudeerden waarmee op dit soort vragen een antwoord kan worden gegeven. Het voorliggende rapport Schoolverlaters tussen onderwijs en arbeidsmarkt 2009 gaat in op de transitie van school naar werk of vervolgonderwijs van gediplomeerde schoolverlaters en afgestudeerden van het school- of studiejaar 2007/2008. De resultaten die worden gepresenteerd zijn gebaseerd op het onderzoek dat eind 2009 over de volle breedte van het Nederlandse onderwijsstelsel is uitgevoerd, en hebben betrekking op de situatie van schoolverlaters en afgestudeerden ongeveer anderhalf jaar na het voltooien van de opleiding. In totaal zijn 98.I28 schoolverlaters en afgestudeerden benaderd. De totale respons bedroeg 30\%. De verzamelde gegevens vormen samen het door het ROA ontwikkelde SchoolverlatersinformatieSysteem (SIS). Dit informatiesysteem is gebaseerd op een viertal grootschalige enquêtes die volgens een geïntegreerd model worden uitgevoerd.

Allereerst betreft het de VO-Monitor. Deze enquête is gericht op schoolverlaters van het algemeen voortgezet onderwijs (HAVO, VWO) en het voorbereidend beroepsonderwijs (VMBO). Vervolgens de BVE-Monitor, een enquête onder schoolverlaters van de beroepsopleidende (BOL) en beroepsbegeleidende leerweg (BBL) van het secundair beroepsonderwijs. Tot slot de HBO-Monitor en WO-Monitor. Deze enquêtes zijn gericht op afgestudeerden van het hoger beroepsonderwijs (HBO) en het wetenschappelijk onderwijs (WO). Ze worden uitgevoerd onder auspiciën van respectievelijk de HBO-raad en de Vereniging van Samenwerkende Nederlandse Universiteiten (VSNU). De VSNU heeft besloten om met ingang van 2008 de WO-Monitor niet meer jaarlijks uit te voeren maar tweejaarlijks en bovendien de uitvoering aan het IVA uit te besteden. Om de laatstgenoemde reden zijn gegevens over het WO voor meting 2009 niet altijd vergelijkbaar met de andere onderwijsniveaus. Als gevolg hiervan ontbreken gegevens over het WO in een aantal tabellen, figuren en additioneel uitgevoerde analyses. We danken de VSNU voor het gebruik van de WO data.

Het ROA heeft de algehele projectleiding van SIS en is specifiek verantwoordelijk voor de instrumentontwikkeling en de wetenschappelijke analyse en rapportage. DESAN Research Solutions is verantwoordelijk voor de dataverzameling en -verwerking, alsmede voor de specifieke rapporten voor de deelnemende onderwijsinstellingen. Over de dataverzameling en -verwerking verschijnt tweejaarlijks een apart werkdocument bij het ROA.

De vier schoolverlatersonderzoeken hebben ieder een tweeledige doelstelling. In de eerste plaats fungeren ze als instrument voor kwaliteitszorg voor onderwijsinstellingen. 
Deelnemende onderwijsinstellingen ontvangen daartoe een uniek en vertrouwelijk instellingsrapport met de resultaten van hun 'eigen' schoolverlaters of afgestudeerden. In de desbetreffende rapporten worden deze resultaten direct vergeleken met het landelijke beeld voor de onderscheiden opleidingen. Deze instellingsrapporten worden gebruikt als instrument om de eigen opleiding te evalueren, bijvoorbeeld in het kader van een visitatie. Ook worden de gegevens gebruikt om (aankomende) studenten voor te lichten over de verwachte beroepsperspectieven. De tweede doelstelling van de vier schoolverlatersonderzoeken betreft het genereren van een statistisch betrouwbare, landelijk representatieve databron over de transitie van school naar werk of vervolgonderwijs. Door het grootschalige karakter van de onderzoeken en de goede onderlinge afstemming vormen de huidige schoolverlatersonderzoeken VO-Monitor, BVE-Monitor, HBO-Monitor en WO-Monitor de belangrijkste en meest gedetailleerde informatiebron over de bestemming van schoolverlaters in Nederland.

Dit rapport richt zich vooral op degenen die zich in beleidsmatige zin bezighouden met de doorstroom van gediplomeerde schoolverlaters binnen het onderwijssysteem enerzijds en de arbeidsmarktpositie van gediplomeerde schoolverlaters anderzijds. Daarbij wordt met name gedacht aan de landelijke en regionale overheid, sociale partners, het UWV Werkbedrijf, particuliere intermediairs en het (georganiseerde) onderwijsveld. De gegevens in dit rapport geven een beeld van het recente doorstroomgedrag en arbeidsmarktpositie van gediplomeerde schoolverlaters.

Het rapport Schoolverlaters tussen onderwijs en arbeidsmarkt 2009 omvat zowel de rapportage over de actuele situatie van de gediplomeerde schoolverlaters als de statistische bijlage waarin de belangrijkste resultaten van meting 2009 in tabelvorm zijn samengebracht. De tabellen uit deze statistische bijlage zijn voor het $\mathrm{VMBO}$, het $\mathrm{VO}$, het $\mathrm{MBO}$ en het $\mathrm{HBO}$ ook op opleidingsniveau beschikbaar. Deze zijn te vinden op www.roa.unimaas.nl/kerncijfers.htm. Over de resultaten van meting 2009 verschijnt ook een ROA Factsheet Schoolverlaters tussen onderwijs en arbeidsmarkt 2009. Feiten en cijfers. Voor meer informatie over de schoolverlatersonderzoeken wordt verwezen naar de website van het ROA: www.roa.nl.

Naast de voorliggende rapportage is over meting 2009 reeds verslag gedaan in een tweetal rapporten van het ROA, namelijk het rapport $M B O$-diploma in tijden van crisis. Doorleren of werk zoeken? (Meng, Huijgen, Ramaekers, 2010) en het rapport MBO: Tevredenheid en aansluiting met vervolgonderwijs en arbeidsmarkt (Meng, Soudant, van Thor, 20IO). Daarnaast zal de HBO-raad dit jaar het verslag Feiten en cijfers. HBO-Monitor 2009: De arbeidsmarktpositie van afgestudeerden van het hoger beroepsonderwijs uitbrengen. Het ROA zal verder nog een rapportage over voortijdige schoolverlaters en een rapportage over het AVO uitbrengen.

De projectleiding van Schoolverlaters tussen onderwijs en arbeidsmarkt 2009 berust bij dr. C.M. Meng. De Statistische Bijlage is samengesteld door P.J.E.G van der Kolk en E.M.H.P. Soudant. De eindredactie is in handen van dr. C.M. Meng en drs. G.W.M. Ramaekers. Secretariële ondersteuning is verleend door M.H.J. Beenkens. Voornoemde personen zijn allen werkzaam bij het ROA. Aan SIS, waarop dit rapport is gebaseerd, werken verder mee drs. M.C.M.Th. van Alphen, drs. J.M.R. van Dongen en drs. B.M. Kinket (allen werkzaam bij DESAN Research Solutions). Een speciale dank is gericht aan P. Dijkstra, N. Nijdam, drs. J.D. de Vries en I. Dijkema (allen werkzaam bij de Informatie Beheer Groep te Groningen) 
voor de medewerking bij het uitzetten van de steekproeven onder zowel de gediplomeerde als de ongediplomeerde schoolverlaters van het VMBO, het MBO, het AVO en het WO.

Een speciaal woord van dank wordt gericht aan de vertegenwoordigers van de financiers die in de klankbordgroep zitting hebben: drs. R. Jongsma (werkzaam bij het Ministerie van Sociale Zaken en Werkgelegenheid), drs. U. Teunis (werkzaam bij het Ministerie van Landbouw, Natuur en Voedselkwaliteit), F. de Graaf, J.A. de Hoog, drs. drs. B. Verlaan en drs. M. Warmerdam (allen werkzaam bij het Ministerie van Onderwijs, Cultuur en Wetenschap).

Maastricht, juni 2010

Prof. dr. T.J. Dohmen

directeur 


\section{Samenvatting}

Aan de hand van een drietal functies van onderwijs (kwalificatie, selectie, allocatie) en het extern rendement (opbrengsten in vervolgonderwijs en op de arbeidsmarkt) van onderwijs wordt hieronder een samenvattend beeld geschetst van het gehele onderwijsveld op basis van resultaten uit de meting die eind 2009 onder gediplomeerde schoolverlaters heeft plaatsgevonden.

\section{Kwalificatie}

De kwalificatiefunctie van onderwijs draait om de vraag in hoeverre het onderwijs er in is geslaagd om de schoolverlaters afdoende uit te rusten met de competenties welke relevant zijn voor de doorstroming naar een vervolgopleiding of de arbeidsmarkt. Om dit na te gaan is in dit rapport gekeken naar het oordeel van de schoolverlaters over de breedte en diepgang van de opleiding en naar de vraag in hoeverre de opleiding een goede basis biedt om te starten op de arbeidsmarkt c.q. kennis en vaardigheden verder te ontwikkelen.

De overgrote meerderheid van de schoolverlaters is tevreden over de breedte van de opleiding $(83 \%)$ en de diepgang van de opleiding $(8 \mathrm{I} \%)$. Schoolverlaters schatten hun ontwikkelpotentieel hoger in (61\% tevreden) dan hun startbekwaamheid (44\% tevreden).

\section{Selectie}

De selectiefunctie van onderwijs betreft het beoordelen van studenten op de aanwezige competenties en het op grond hiervan certificeren naar eindniveau. Het oordeel van de schoolverlaters over de selectiviteit van hun opleiding is gebaseerd op hun mening over de moeilijkheidsgraad en het niveau van hun opleiding en hun mening over een drietal aspecten van de beoordeling van hun studievoortgang.

De overgrote meerderheid (79\%) van de gediplomeerde schoolverlaters is niet ontevreden over de moeilijkheidsgraad van hun opleiding. Dit laat onverlet dat 'maar liefst' $17 \%$ de opleiding te makkelijk vindt, 'slechts' $20 \%$ vindt dat de docenten streng waren in de beoordeling van studenten, 'slechts' $3 \mathrm{I} \%$ de opleiding uitdagend qua niveau vond, 'slechts' $26 \%$ de tentamens/opdrachten over het algemeen als zeer pittig heeft ervaren en nog niet de helft ( $40 \%)$ vindt dat er voldoende is getoetst op inzicht. Kortom, een niet te verwaarlozen deel van de gediplomeerde schoolverlaters in Nederland vindt dat hun opleiding best wat selectiever had mogen zijn.

\section{Allocatie}

De allocatiefunctie van onderwijs betreft de vraag of het onderwijs de schoolverlaters op een adequate wijze toeleidt naar een vervolgopleiding of de arbeidsmarkt. De allocatiefunctie die betrekking heeft op dat deel van de schoolverlaters dat naar een vervolgopleiding doorstroomt is gebaseerd op (I) de vraag of zij doorstromen naar een verwante opleidingsrichting 
en (2) de tevredenheid met de aansluiting tussen gevolgde opleiding en vervolgopleiding. De allocatiefunctie die betrekking heeft op dat deel van de schoolverlaters dat naar de arbeidsmarkt doorstroomt is gebaseerd op (I) de vraag of de functie qua vereist opleidingsniveau en vereiste opleidingsrichting bij de gevolgde opleiding past, (2) de benutting van de capaciteiten in de huidige functie en (3) de tevredenheid met de huidige functie.

Van alle gediplomeerde schoolverlaters stroomt 63\% (meting 2008 eveneens 63\%) door naar vervolgonderwijs. Van deze doorstromers stroomt ruim de helft (59\%) door naar een verwante vervolgopleiding, en vindt bijna driekwart $(74 \%)$ dat de vervolgopleiding redelijk tot goed aansluit op de afgeronde opleiding.

Ruim de helft (54\%; meting 2008: 55\%) van de gediplomeerde schoolverlaters richt zich na het verlaten van de opleiding op de arbeidsmarkt. Van alle betaald werkende schoolverlaters heeft driekwart ( $74 \%$; vorige meting $77 \%$ ) een baan op minimaal het eigen opleidingsniveau, en $70 \%$ (meting 2008: 71\%) een functie waarvoor de eigen of een verwante opleidingsrichting vereist is. Ten opzichte van meting 2008 is het aandeel van de betaald werkende schoolverlaters met een baan die past bij hun opleidingsniveau dus licht gedaald. Van de betaald werkende schoolverlaters geeft bijna tweederde (64\%) aan dat de opgedane kennis en vaardigheden in hun werk goed worden benut. Bijna driekwart (72\%) van de betaald werkende schoolverlaters is tevreden met de huidige functie.

\section{Extern rendement}

Bij het extern rendement met betrekking tot de doorstroom naar vervolgonderwijs gaat het om de prestaties in het vervolgonderwijs. Bij het extern rendement met betrekking tot de arbeidsmarkt gaat het om de kans op werk, de mate van werk en de beloning.

In totaal geeft $13 \%$ van de verder lerende schoolverlaters aan inmiddels gestopt te zijn met de aanvankelijk gekozen vervolgopleiding. Van de I3\% met de vervolgopleiding gestopte schoolverlaters is $9 \%$-punt studiewisselaar, en dus niet verloren voor het onderwijs.

Van de schoolverlaters die zich op de arbeidsmarkt aanbieden, is 6\% werkloos. Dit is I\%-punt meer dan in meting 2008. Hierbij dient te worden bedacht dat de onderzochte schoolverlaters in schooljaar 2007-2008 hun diploma hebben behaald, dus net voordat de economische crisis begon. Vier van de tien betaald werkende schoolverlaters werken in deeltijd (minder dan 33 uur per week). Gemiddeld verdienen de betaald werkende schoolverlaters $€$ II,O2 bruto per uur.

\section{Tevredenheid achteraf}

Gemiddeld zou $84 \%$ van de verder lerende schoolverlaters, achteraf bezien, opnieuw kiezen voor de door hen afgeronde opleiding. De tevredenheid van de gediplomeerde schoolverlaters over hun afgeronde opleiding is dus, alles bezien, groot.

In tabel S.I zijn nog enkele kernindicatoren opgenomen per onderwijssoort. Bij de kernindicatoren met betrekking tot het $\mathrm{MBO}$ dient te worden bedacht dat gediplomeerden van de BBL gemiddeld bijna 8 jaar ouder zijn dan gediplomeerden van de BOL. 
Tabel S.1

Enkele kernindicatoren per onderwijssoort

\begin{tabular}{|c|c|c|c|c|c|c|c|c|}
\hline & Verder leren & $\begin{array}{l}\text { Aanbieden } \\
\text { op de } \\
\text { arbeidsmarkt }\end{array}$ & Werkloosheid & $\begin{array}{c}\text { Flexibele } \\
\text { aanstelling }\end{array}$ & $\begin{array}{l}\text { Bruto } \\
\text { uurloon }\end{array}$ & $\begin{array}{c}\text { Minimaal } \\
\text { eigen niveau }\end{array}$ & $\begin{array}{l}\text { Eigen/ } \\
\text { verwante } \\
\text { richting }\end{array}$ & $\begin{array}{c}\text { Zelfde } \\
\text { opleiding }\end{array}$ \\
\hline & $\%$ & $\%$ & $\%$ & $\%$ & $€$ & $\%$ & $\%$ & $\%$ \\
\hline AVO & 89 & 10 & 16 & 42 & 6,96 & $x$ & $x$ & 96 \\
\hline VMBO & 95 & 28 & 6 & 63 & 4,83 & 86 & 51 & 82 \\
\hline BOL 1 & 51 & 58 & 30 & 61 & 6,57 & 57 & 54 & 68 \\
\hline BOL 2 & 59 & 57 & 12 & 54 & 7,85 & 68 & 58 & 73 \\
\hline BOL 3 & 43 & 71 & 11 & 43 & 10,04 & 76 & 76 & 77 \\
\hline BOL 4 & 55 & 56 & 6 & 44 & 10,36 & 85 & 76 & 79 \\
\hline BBL 1 & 25 & 90 & 9 & 20 & 9,28 & 51 & 41 & 87 \\
\hline BBL 2 & 33 & 95 & 3 & 30 & 10,12 & 62 & 61 & 84 \\
\hline BBL 3 & 21 & 96 & 3 & 25 & 11,72 & 61 & 78 & 83 \\
\hline BBL 4 & 18 & 94 & 1 & 13 & 13,13 & 82 & 83 & 84 \\
\hline $\mathrm{HBO}$ & 36 & 83 & 6 & 46 & 13,36 & 82 & 80 & 78 \\
\hline wo & 31 & 94 & 5 & $x$ & 15,76 & 67 & 73 & 86 \\
\hline Totaal & 63 & 54 & 6 & 41 & 11,02 & 74 & 70 & 84 \\
\hline
\end{tabular}

Bron: ROA (SIS); VSNU/IVA, 2009

$\mathrm{x}$

Verder leren
$=$ geen (vergelijkbaar) cijfer beschikbaar.

$=\%$ respondenten dat in aansluiting op de gevolgde opleiding een vervolgopleiding (incl. duale opleidingen) is gaan volgen.

Aanbieden op de arbeidsmarkt $=\%$ respondenten dat zich aanbiedt op de arbeidsmarkt (inclusief degenen die leren en werken combineren in duale opleidingen)

$=$ werkzoekenden als $\%$ van de schoolverlaters die zich op de arbeidsmarkt aanbieden.

$=\%$ van de werkende schoolverlaters met een aanstelling als uitzendkracht, oproepkracht e.d. of een tijdelijke aanstelling.

$=$ Bruto uurloon in de hoofdfunctie inclusief toeslagen maar exclusief inkomen uit overwerk. Uurloon afgerond op 5 cent.

$=\%$ van de werkende schoolverlaters dat aangeeft dat de werkgever voor deze functie minimaal een diploma van het gevolgde onderwijsniveau eist.

$=\%$ van de werkende schoolverlaters dat aangeeft dat de werkgever voor deze functie een diploma van de gevolgde opleidingsrichting of een verwante opleidingsrichting eist.

$=\%$ van de schoolverlaters dat aangeeft, achteraf bezien, dezelfde opleiding opnieuw te zullen kiezen. 


\section{Kwaliteit van schoolverlaters}

In dit rapport wordt ingegaan op de vraag hoe het de gediplomeerde schoolverlaters is vergaan nadat ze de opleiding in 2008 hebben verlaten ${ }^{\mathrm{I}}$. Dit gebeurt aan de hand van enkele indicatoren die samen iets zeggen over het succes van de transitie naar vervolgonderwijs of arbeidsmarkt. In die zin kunnen de gehanteerde indicatoren een indicatie geven van de kwaliteit van de output van het onderwijs, zoals we dat kunnen vaststellen bij schoolverlaters.

De kwaliteit van onderwijs wordt doorgaans vanuit twee invalshoeken beoordeeld: het onderwijs moet doeltreffend (effectief) zijn en het moet doelmatig (efficiënt) zijn. De doeltreffendheid is ontleend aan de functies die het onderwijs moet vervullen: kwalificatie, selectie en allocatie (Peschar \& Wesselingh, 200I). De doelmatigheid wordt vastgesteld op basis van het extern rendement: dit betreft de opbrengsten op de arbeidsmarkt of in vervolgonderwijs voor de schoolverlaters.

Voor elk van de onderscheiden aspecten - kwalificatie, selectie, allocatie en extern rendement - zijn meerdere indicatoren ontwikkeld. Naast de genoemde aspecten wordt ook gekeken naar de tevredenheid van de schoolverlater met de gevolgde opleiding. Dit kan beschouwd worden als een indicator van de mate waarin verwachtingen van studenten overeenkomen met de feitelijke ervaringen.

\section{Kwalificatiefunctie}

Voor een goede doorstroom naar vervolgonderwijs of de arbeidsmarkt is het noodzakelijk dat de schoolverlater in voldoende mate beschikt over de vereiste competenties. Bij de kwalificatiefunctie van het onderwijs gaat het om de vraag in hoeverre het onderwijs er in is geslaagd om schoolverlaters met deze competenties toe te rusten. Hierbij gaat het niet alleen om de startbekwaamheid van de schoolverlaters (de korte termijn doelstelling van het onderwijs), maar ook om de mate waarin de opleiding een voldoende basis heeft geboden voor de verdere ontwikkeling van 'novice' tot 'expert' (ontwikkelpotentieel) en voor de mate waarin de opleiding heeft bijgedragen aan de algehele 'employability' van de schoolverlater (de lange termijn doelstellingen).

\section{Selectiefunctie}

De betrouwbaarheid waarmee het onderwijs haar studenten beoordeelt op de aanwezige competenties en op grond hiervan een eindniveau certificeert is van groot belang. De legiti-

I. Gediplomeerde schoolverlaters worden in deze rapportage gedefinieerd als schoolverlaters die in het schooljaar 2007-2008 hun diploma behaald hebben. Hierbij speelt het geen rol of dit diploma het predicaat "startkwalificatie" in de zin van een diploma op minimaal MBO niveau 2 heeft of niet. 
mering van de kwalificatiefunctie van het onderwijs is namelijk voor een groot deel gelegen in deze betrouwbaarheid. Zowel onderwijsinstellingen zelf als bijvoorbeeld werkgevers zullen er op moeten kunnen vertrouwen dat een schoolverlater met een bepaald eindcertificaat ook daadwerkelijk beschikt over de competenties die bij het betreffende diploma horen. Over deze betrouwbaarheid van deze selectie zijn echter maar weinig gegevens beschikbaar. In dit verslag maken we gebruik van de oordelen van de schoolverlaters over de selectiviteit van hun opleiding.

\section{Allocatiefunctie}

De allocatiefunctie richt zich op de ondersteuning bij de transitie naar vervolgonderwijs c.q. arbeidsmarkt en op de aansluiting tussen de gekozen vervolgstudie of de gevonden baan en de gevolgde opleiding. Dit kan onder andere door te kijken in hoeverre het onderwijs de schoolverlaters voldoende heeft voorgelicht over de mogelijkheden in het vervolgonderwijs of op de arbeidsmarkt. Met betrekking tot de aansluiting kan bijvoorbeeld gekeken worden naar de vraag in hoeverre men werk gevonden heeft dat wat betreft niveau en richting aansluit bij het niveau en de richting van de afgeronde opleiding.

\section{Opbrengsten van onderwijs (extern rendement)}

In dit rapport kijken we bij het extern rendement voor zover het de arbeidsmarkt betreft naar een drietal indicatoren, te weten: (I) het werkloosheidspercentage $\mathrm{I}^{1 / 2} / 2$ jaar na het verlaten van de opleiding, (2) het bruto uurloon $\mathrm{I}^{1 / 2}$ jaar na het verlaten van de opleiding en (3) de carrièremogelijkheden van de gevonden baan. Wat het extern rendement betreft voor schoolverlaters die naar een vervolgopleiding doorstromen, kijken we (I) naar het percentage van hen dat in de eerste anderhalf jaar alweer gestopt of van studie gewisseld is en (2) naar het percentage van hen dat bevorderd is naar het tweede/volgende leer- of studiejaar.

\section{Tevredenheid achteraf}

Vooral voor onderwijsinstellingen is het van belang om te weten in welke mate de gediplomeerde uitstroom achteraf weer voor dezelfde opleiding en dezelfde school zou kiezen. Met andere woorden, zijn de schoolverlaters tevreden over de gekozen opleiding en de gekozen school? Schoolverlaters wordt daarom de vraag voorgelegd of ze achteraf gezien opnieuw dezelfde opleiding zouden kiezen. De tevredenheid wordt bepaald door de mate waarin de ervaringen van de schoolverlaters met betrekking tot hun opleiding overeenkomen met hun verwachtingen. Omdat dit oordeel op een groot aantal aspecten gebaseerd is geeft het als het ware een samenvattend oordeel over de kwaliteit van het onderwijs.

In tabel I.I staat het hierboven besproken kader kort samengevat. Per aspect wordt aangegeven welke indicatoren aan bod komen. Tussen haakjes wordt aangegeven in welk hoofdstuk deze aan de orde komen.

Zoals uit tabel I.I blijkt is het rapport als volgt opgebouwd. In hoofdstuk 2 wordt op basis van een aantal indicatoren de kwalificatiefunctie van het onderwijs in kaart gebracht. In hoofdstuk 3 staat vervolgens de selectiefunctie centraal. In hoofdstuk 4 wordt nader ingegaan op schoolverlaters die een kwalificerend vervolgtraject volgen. Hierbij wordt ingegaan op 
de aspecten allocatie en rendement en de mate waarin de schoolverlaters, achteraf gezien, de afgesloten opleiding opnieuw zouden zijn gaan volgen. Hoofdstuk 5 richt zich op de schoolverlaters die zich na het behalen van het diploma op de arbeidsmarkt aangeboden hebben. Ook hier komen weer de aspecten allocatie, rendement en tevredenheid aan bod. Tot slot staan we in hoofdstuk 6 kort stil bij de gevolgen van de economische crisis voor schoolverlaters.

Tabel 1.1

Overzicht indicatoren

\begin{tabular}{|c|c|c|c|}
\hline Invalshoek & Aspect & \multicolumn{2}{|l|}{ Indicator } \\
\hline \multirow[t]{3}{*}{ Doeltreffendheid } & Kwalificatie (2) & $\begin{array}{l}\text { breedte van de opleiding } \\
\text { diepgang van de opleiding } \\
\text { opleiding als basis voor start op arbeid } \\
\text { opleiding als basis voor verdere ontwik }\end{array}$ & sen vaardigheden \\
\hline & Selectie (3) & $\begin{array}{l}\text { moeilijkheidsgraad opleiding } \\
\text { strenge beoordeling door docenten } \\
\text { opleiding uitdagend niveau } \\
\text { pittige examens } \\
\text { toetsing op inzicht }\end{array}$ & \\
\hline & Allocatie & $\begin{array}{l}\text { Doorstroom naar vervolgonderwijs (4) } \\
\text { doorstroom naar verwante opleiding } \\
\text { aansluiting met vervolgopleiding }\end{array}$ & $\begin{array}{l}\text { Doorstroom naar arbeidsmarkt (5) } \\
\text { functie op minimaal eigen niveau } \\
\text { functie in eigen/verwante richting } \\
\text { benutting kennis en vaardigheden } \\
\text { kennis en vaardigheden schieten tekort } \\
\text { aansluiting opleiding/functie } \\
\text { tevredenheid met functie }\end{array}$ \\
\hline Doelmatigheid & Extern rendement & $\begin{array}{l}\text { Doorstroom naar vervolgonderwijs (4) } \\
\text { vervolgopleiding voortijdig verlaten } \\
\text { studiewisselaars vervolgopleiding } \\
\text { bevorderd naar tweede leerjaar }\end{array}$ & $\begin{array}{l}\text { Doorstroom naar arbeidsmarkt (5) } \\
\text { werkloosheid } \\
\text { zoekduur eerste baan } \\
\text { flexibele aanstelling } \\
\text { deeltijdaanstelling } \\
\text { bruto uurloon } \\
\text { carrièreperspectieven }\end{array}$ \\
\hline Tevredenheid achteraf & & $\begin{array}{l}\text { Doorstroom naar vervolgonderwijs (4) } \\
\text { zelfde opleiding opnieuw kiezen }\end{array}$ & $\begin{array}{l}\text { Doorstroom naar arbeidsmarkt (5) } \\
\text { zelfde opleiding opnieuw kiezen }\end{array}$ \\
\hline
\end{tabular}




\section{Kwalificatie}

Voor een succesvolle start op de arbeidsmarkt of het met succes kunnen volgen van een vervolgstudie is het een eerste vereiste dat de schoolverlater beschikt over de benodigde competenties. In hoeverre het onderwijs er in is geslaagd de schoolverlater de benodigde competenties bij te brengen is het aandachtspunt van het aspect kwalificatie. Voor schoolverlaters die naar de arbeidsmarkt doorstromen, is hierbij niet alleen relevant of de opleiding hen startbekwaam heeft gemaakt (de korte termijn doelstelling van het onderwijs), maar ook of de opleiding een goede basis biedt voor de verdere ontwikkeling van 'novice' tot 'expert' (ontwikkelpotentieel) en voor de algehele 'employability' van de schoolverlaters (de lange termijn doelstelling).

Om hier inzicht in te krijgen is de schoolverlaters gevraagd de afgeronde opleiding te beoordelen op een viertal aspecten: (I) de breedte van de opleiding (te smal $<-->$ te breed), (2) de diepgang van de opleiding (te weinig diepgang $<->$ te veel diepgang), (3) de mate waarin de opleiding een goede basis biedt om te starten op de arbeidsmarkt en (4) de mate waarin de opleiding een goede basis biedt om kennis en vaardigheden verder te ontwikkelen. De eerste twee aspecten zeggen iets over de evenwichtigheid van het studieprogramma, terwijl de laatste twee aspecten iets zeggen over de voorbereiding op de arbeidsloopbaan. Voor deze aspecten van de opleiding zijn geen gegevens voor het WO beschikbaar.

\section{Schoolverlateroordeel over breedte van de opleiding}

De eerste indicator voor de evenwichtigheid van het studieprogramma wordt gevormd door het oordeel van de schoolverlaters over de breedte van hun opleiding. Aan de schoolverlaters is gevraagd om op een 7-puntschaal (van I 'veel te smal' naar 7 'veel te breed') een oordeel te geven over de breedte van de afgeronde opleiding. Figuur 2.I laat per onderwijssoort het percentage schoolverlaters zien dat hun gevolgde opleiding te smal (antwoordcategorie I en 2) of te breed (antwoordcategorie 6 en 7 ) vindt. De overgrote meerderheid (83\%) van de schoolverlaters is tevreden over de breedte van de opleiding. Van degenen die niet tevreden zijn, vinden meer schoolverlaters dat de opleiding te breed is (II\%) dan dat de opleiding te smal is $(6 \%)$. Vooral afgestudeerden van het $\mathrm{HBO}$ vinden met $24 \%$ vaak dat hun opleiding te breed is. Met name de HBO opleidingen uit de sector economie zijn volgens veel afgestudeerden te breed. 
Figuur 2.1

Breedte van opleiding

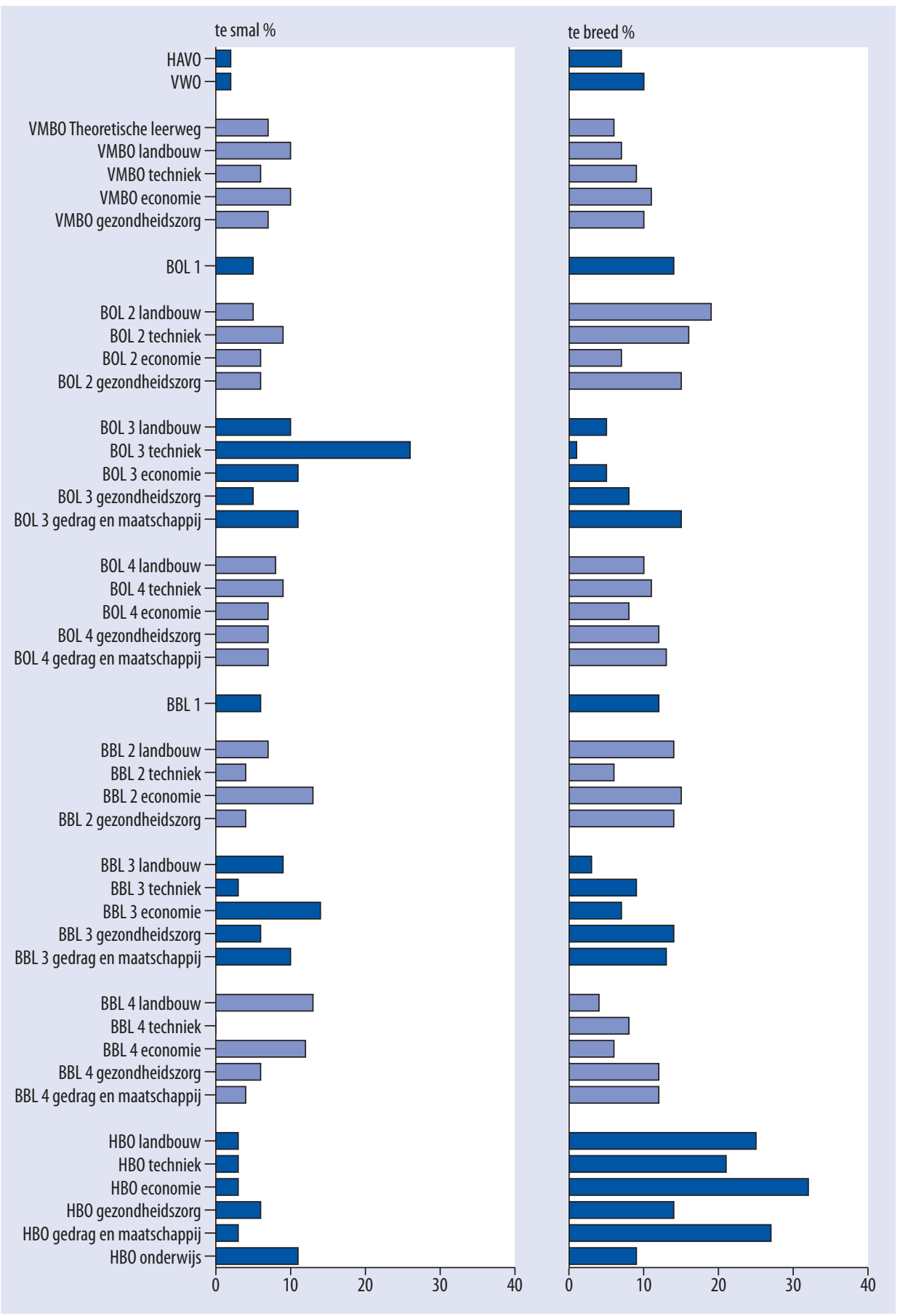

Bron: ROA (SIS) 


\section{Figuur $\mathbf{2 . 2}$}

Diepgang van opleiding

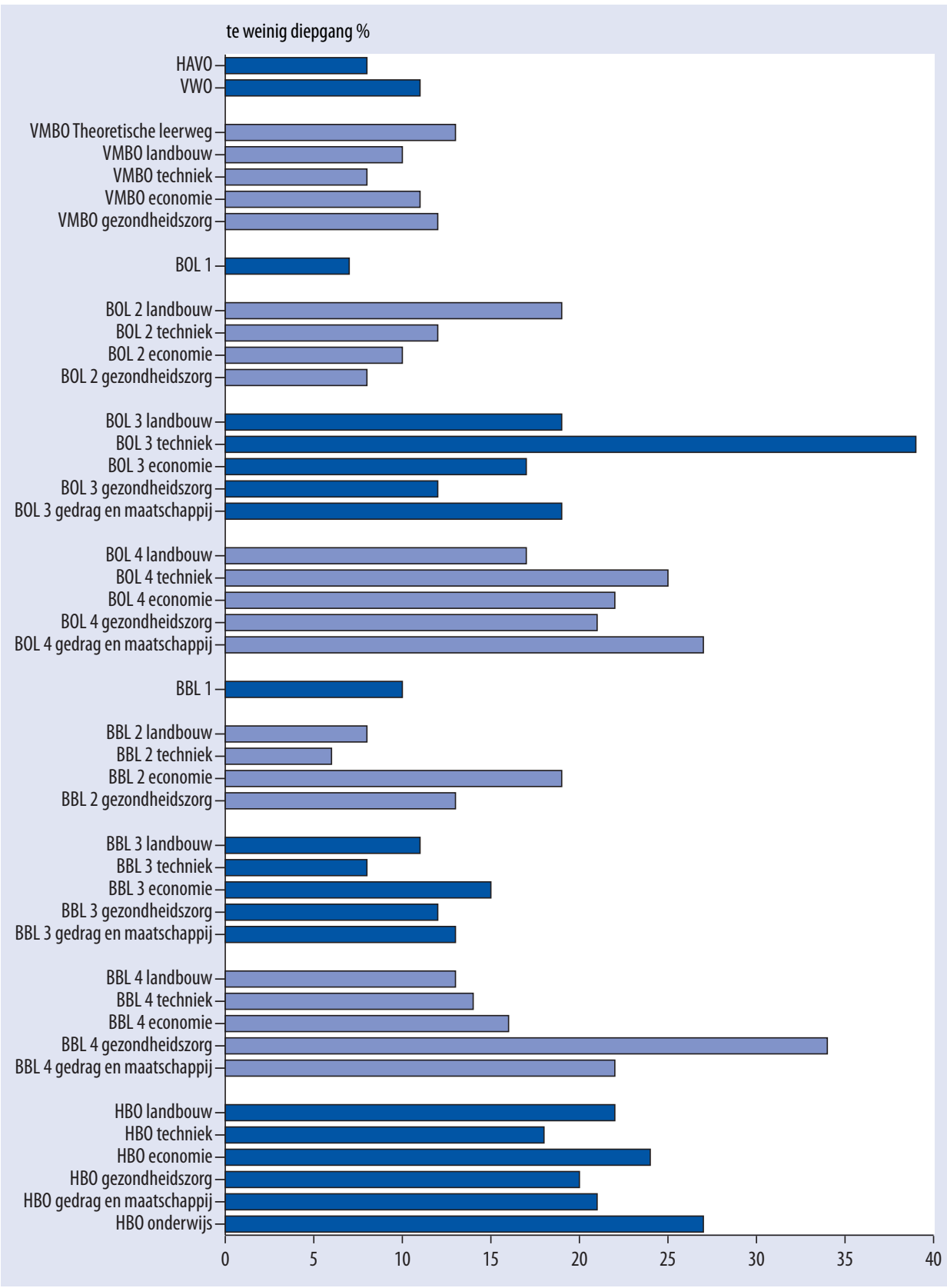

Bron: ROA (SIS) 


\section{Schoolverlateroordeel over diepgang van de opleiding}

Naast de breedte van de opleiding is aan de schoolverlaters gevraagd om op een 7-puntschaal (van I 'te weinig diepgang' naar 7 'te veel diepgang') hun mening te geven over de diepgang van de opleiding. In figuur 2.2 staat het percentage schoolverlaters dat vindt dat de opleiding te weinig diepgang (antwoordcategorie I en 2) heeft. Van alle schoolverlaters is $14 \%$ van oordeel dat de opleiding te weinig diepgang heeft. Op HBO niveau vindt men dit met $22 \%$ het vaakst (vooral de $\mathrm{HBO}$ sectoren onderwijs en economie), en op VO niveau het minst vaak (9\%). Binnen het MBO zijn de gediplomeerden uit het duale onderwijs (BBL) iets vaker tevreden over de diepgang van hun opleiding dan de gediplomeerden uit het reguliere onderwijs (BOL). Binnen de BOL zijn het vooral de niveau 3 en 4 opleidingen gedrag en maatschappij en techniek die volgens de oud leerlingen te weinig diepgang hebben. In zowel de BBL als de BOL stijgt het percentage schoolverlaters dat vindt dat de opleiding te weinig diepgang heeft overigens met het niveau van de opleiding.

Tegenover de $14 \%$ die vindt dat hun opleiding te weinig diepgang had, staat $5 \%$ die vindt dat hun opleiding te veel diepgang had. De overgrote meerderheid $(8 \mathrm{r} \%)$ kan dus goed leven met de diepgang van hun opleiding.

\section{Schoolverlateroordeel over startbekwaamheid en ontwikkelpotentieel}

De belangrijkste doelstelling van het onderwijs vanaf $\mathrm{MBO}$ niveau 2 is het voorbereiden van mensen voor de arbeidsmarkt. Om na te gaan of het onderwijs de leerlingen/studenten afdoende heeft toegerust voor de arbeidsmarkt wordt ingegaan op het oordeel van de schoolverlaters over de mate waarin de afgeronde opleiding hen heeft voorbereid op de beroepspraktijk. Eerst wordt in figuur 2.3 aangegeven in hoeverre zij vinden dat hun opleiding hen startbekwaam heeft gemaakt voor de arbeidsmarkt (de korte termijn doelstelling van het onderwijs). Opleidingen dienen echter ook te worden beoordeeld op de vraag of ze een voldoende basis bieden voor de verdere ontwikkeling van 'novice' tot 'expert' (ontwikkelpotentieel) en voor de algehele 'employability' van de afgestudeerden (de lange termijn doelstelling). Daartoe is aan de schoolverlaters ook gevraagd in hoeverre de afgeronde opleiding een goede basis biedt om kennis en vaardigheden verder te ontwikkelen.

Aan de gediplomeerde schoolverlaters is gevraagd om op een 5-puntschaal (I 'helemaal niet' <-> 5 'in sterke mate') achtereenvolgens aan te geven in welke mate hun opleiding hen startbekwaam heeft gemaakt voor de arbeidsmarkt en in hoeverre hun opleiding een goede basis heeft verschaft om zich beroepsmatig verder te kunnen ontwikkelen. Figuur 2.3 geeft een indicatie in hoeverre het onderwijs hierin is geslaagd (antwoordcategorie 4 en 5). Uit de figuur blijkt dat schoolverlaters hun ontwikkelpotentieel hoger inschatten dan hun startbekwaamheid. Van de gediplomeerde uitstroom vindt $44 \%$ dat de gevolgde opleiding een goede basis is om te starten op de arbeidsmarkt. Dit percentage is het laagst bij het VMBO (een kwart van hen vindt de opleiding een goede basis voor de arbeidsmarktintrede) en het hoogst bij de BBL en het HBO. Ondanks het feit dat de opleidingen in het VMBO eigenlijk geen startkwalificatie bieden, en dus niet bedoeld zijn als directe voorbereiding op de arbeidsmarkt, vindt dus blijkbaar toch nog I van de 4 gediplomeerden dat ze een goede basis hebben met een VMBO diploma wanneer ze op zoek gaan naar werk. De meest theoretische variant, de VMBO-tl, scoort begrijpelijkerwijs het laagst. 
In de BBL bieden de langere opleidingen van niveau 3 en 4 een betere basis voor een start op de arbeidsmarkt dan de kortere opleidingen van niveau i en 2. Opvallend in zowel de BOL als de BBL is dat ook de uitstroom van niveau I opleidingen redelijk tevreden is over dit aspect terwijl deze opleidingen formeel gezien geen startkwalificatie zijn. In het gehele MBO zijn de gediplomeerden met een opleiding in de sector gezondheidszorg het meest te spreken over de door de opleiding gelegde basis voor de arbeidsmarkt. Ofschoon de oordelen in het HBO, samen met de BBL, door de bank genomen gunstiger zijn dan in de overige onderwijsniveaus is er op HBO-niveau één opvallend lage score. Zo vinden de afgestudeerden van de HBO sector taal en cultuur hun opleiding maar een matige basis om te starten op de arbeidsmarkt.

Het tweede deel van figuur 2.3 vermeldt de mate waarin de gevolgde opleiding een goede basis is voor het verder ontwikkelen van kennis en vaardigheden. In tegenstelling tot de vraag in hoeverre de opleiding een goede basis is om te starten op de arbeidsmarkt, de korte termijn doelstelling van het onderwijs, zeggen deze cijfers iets over de langere termijn doelstelling van het onderwijs.

Zes van de tien schoolverlaters vinden de gevolgde opleiding een goede basis voor het verder ontwikkelen van kennis en vaardigheden. Evenals bij de vorige indicator is dit percentage het hoogst onder uitstromers van de BBL (vooral de sector gezondheidszorg) en het $\mathrm{HBO}$ (vooral de sectoren techniek, gezondheidszorg en gedrag en maatschappij). 


\section{Figuur 2.3}

Starten op arbeidsmarkt en verder ontwikkelen van kennis en vaardigheden

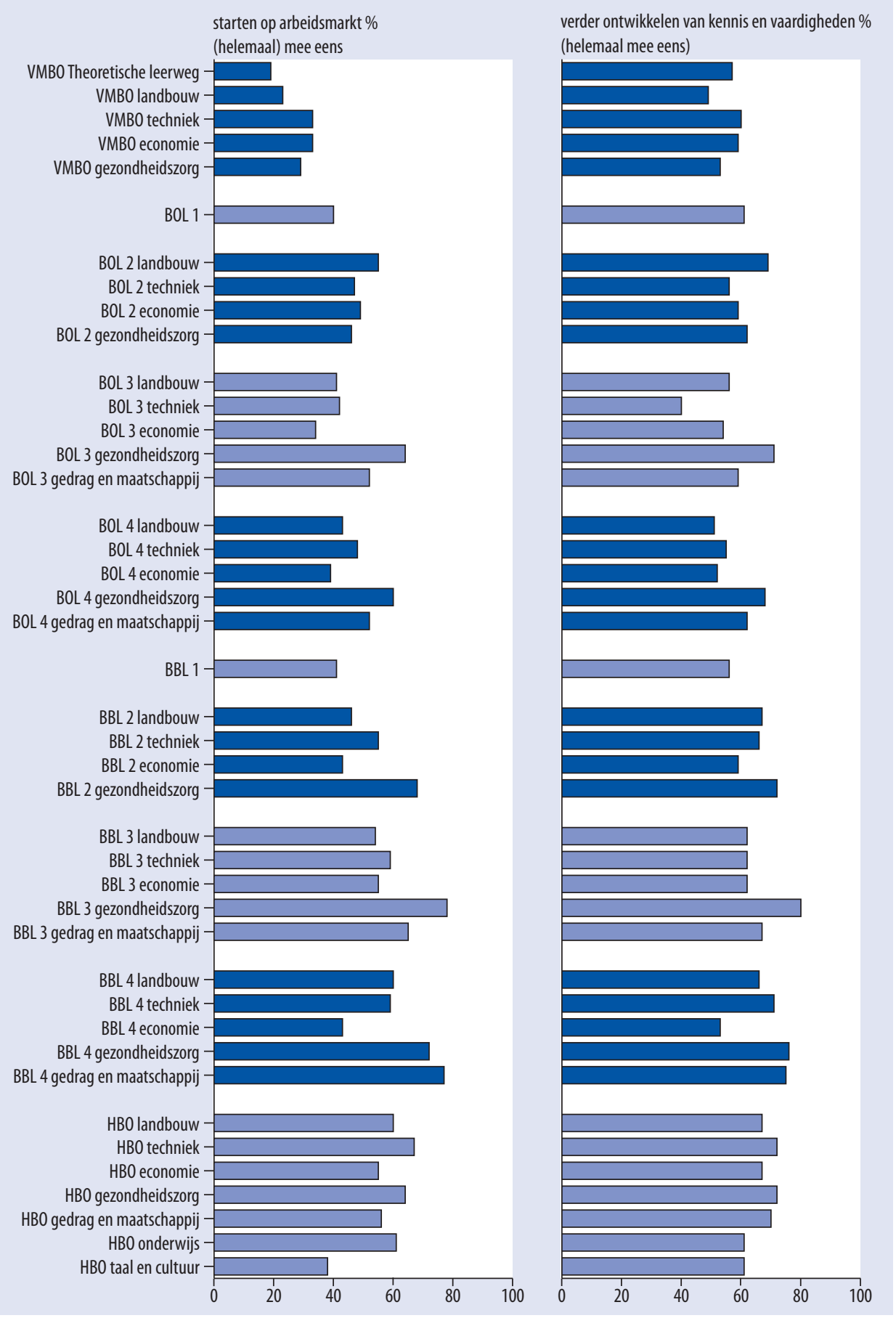

Bron: ROA (SIS) 


\section{Box 2.1: Startbekwaamheid en ontwikkelpotentiee}

In een tweetal analyses is nagegaan met welke opleidingskenmerken de beoordeling van de startbekwaamheid en het ontwikkelpotentieel samenhangt. In de analyses is het oordeel over de startbekwaamheid en het oordeel over het ontwikkelpotentieel gerelateerd aan de genoten onderwijssoort (BOL 1-2, BOL 3-4, BBL 1-2, BBL 3-4 en HBO), het oordeel over de evenwichtigheid van het studieprogramma (breedte, diepgang, moeilijkheidsgraad, keuzemogelijkheden) en het oordeel over het selectief karakter van de opleiding (strengheid beoordeling studenten, uitdagend karakter qua niveau, zwaarte van de toetsen, toetsen op inzicht. Zie hoofdstuk 3 voor een bespreking van deze indicatoren). $0 \mathrm{~m}$ de analyses zo zuiver mogelijk te houden is tevens gecontroleerd voor een drietal persoonskenmerken (geslacht, leeftijd, etniciteit) en het gemiddeld eindexamencijfer. Voor alle kenmerken in de analyse zijn dummyvariabelen ${ }^{2}$ gebruikt, behoudens voor leeftijd en eindexamencijfer. Het oordeel over de startbekwaamheid heeft de waarde 1 gekregen indien de opleiding een goede basis bood (antwoordcategorie 4 of 5) en de waarde 0 indien dit niet het geval was (antwoordcategorie 1, 2 of 3). Op dezelfde wijze is het oordeel over het ontwikkelpotentieel geoperationaliseerd.

\section{Genoten onderwijssoort}

Vergeleken met BOL niveau 3 en 4 gediplomeerden oordelen BOL niveau 1 en 2 gediplomeerden negatiever over hun ontwikkelpotentieel en vooral hun startbekwaamheid, en BBL niveau 3 en 4 gediplomeerden en HBO afgestudeerden positiever over zowel hun startbekwaamheid als hun ontwikkelpotentieel.

\section{Oordeel over evenwichtigheid van de opleiding}

Schoolverlaters die tevreden zijn over de breedte, diepgang en keuzemogelijkheden van hun opleiding zijn beter te spreken over hun startbekwaamheid en ontwikkelpotentieel dan schoolverlaters die minder goed te spreken zijn over deze aspecten van hun opleiding. Een positief oordeel over de moeilijkheidsgraad van de opleiding gaat samen met een positief oordeel over iemands ontwikkelpotentieel.

\section{Oordeel over selectiviteit van de opleiding}

Schoolverlaters die de opleiding uitdagend qua niveau vinden en die van mening zijn dat in de opleiding voldoende werd getoetst op inzicht beoordelen hun startbekwaamheid en ontwikkelpotentieel positiever dan schoolverlaters van opleidingen die minder uitdagend worden gevonden en waarin minder op inzicht werd getoetst. De strengheid waarmee de docenten de studenten beoordeelden en de zwaarte waarmee hun studieprestaties werden getoetst blijken geen voorspellende waarde te hebben ten aanzien van de beoordeling van de startbekwaamheid en het ontwikkelpotentieel.

Kortom, uit de analyses komt naar voren dat evenwichtige en selectieve opleidingen beter kwalificeren voor de intrede op de arbeidsmarkt en latere beroepsloopbaan dan opleidingen die op deze punten minder goed scoren.

Resultaten van regressieanalyses voor het oordeel over startbekwaamheid en het oordeel over ontwikkelpotentieel

$\begin{array}{lcc}\text { Gevolgde onderwijssoort } & \text { Startbekwaamheid } & \text { Ontwikkelpotentieel } \\ \text { - BOL 3-4 (referentie) } & & \\ \text { - BOL 1-2 } & -0,354 & -0,148 \\ \text { - BBL 1-2 } & X & X \\ \text { - BBL 3-4 } & 0,552 & 0,325 \\ \text { - HBO } & 0,444 & 0,432 \\ & & \\ \text { Oordeel evenwichtigheid opleiding } & 0,294 & 0,148 \\ \text { Breedte } & 0,371 & 0,414 \\ \text { Diepgang } & X & 0,103 \\ \text { Moeilijkheidsgraad } & 0,086 & 0,141 \\ \text { Keuzemogelijkheden } & & \\ \text { Oordeel selectiviteit opleiding } & X & X \\ \text { Beoordeling door docenten } & 0,316 & 0,391 \\ \text { Niveau } & X & X \\ \text { Zwaarte toetsen } & 0,214 & 0,240 \\ \text { Inhoud toetsen } & & \\ \text { X Niet significant. } & & \\ & & \end{array}$

Bron: ROA (SIS) 


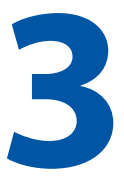

\section{Selectie}

In dit hoofdstuk worden enkele indicatoren gepresenteerd die iets zeggen over de selectiefunctie van het onderwijs. Zoals al eerder is vermeld, is de betrouwbaarheid waarmee het onderwijs op competenties selecteert van wezenlijk belang. Er is aan de schoolverlaters gevraagd om over de volgende vijf aspecten hun mening te geven (I) de moeilijkheidsgraad van de opleiding, (2) de strengheid van de docenten bij het beoordelen van scholieren/ studenten, (3) de mate waarin de opleiding uitdagend was qua niveau, (4) de mate waarin de examens als pittig werden ervaren ( 5 ) de mate waarin op inzicht werd getoetst. ${ }^{3}$ We moeten ons realiseren dat het hierbij gaat om de subjectieve oordelen van de schoolverlaters zelf. Bovendien is dit gevraagd aan degenen die de opleiding hebben afgerond, en zegt het dus meer over de selectiviteit tijdens de opleiding dan over de selectiviteit bij de intrede. Daarbij komt dat het hierbij om de mening van degenen gaat die de opleiding met een diploma hebben voltooid. Scholieren die de opleiding vanwege tegenvallende studieresultaten voortijdig hebben verlaten, zullen wellicht heel anders denken over de selectie tijdens de opleiding. Niettemin geven deze indicatoren een goed beeld over de mate waarin naar het oordeel van de schoolverlaters zelf de opleiding voldoende selectief is geweest.

\section{Schoolverlateroordeel over moeilijkheidsgraad van de opleiding}

Aan de schoolverlaters is gevraagd om op een 7-puntschaal (van I 'veel te laag' naar 7 'veel te hoog') een oordeel te geven over de moeilijkheidsgraad van hun opleiding. In figuur 3.I staan de oordelen van de schoolverlaters met betrekking tot de moeilijkheidsgraad van hun opleiding. $17 \%$ van alle schoolverlaters vindt dat de opleiding te makkelijk is (antwoordcategorie I en 2). Dit varieert van IO\% onder schoolverlaters van het VO tot $28 \%$ onder schoolverlaters van de BOL niveau 4. Binnen het voortgezet onderwijs worden de opleidingen van het hoogste niveau, het VWO, en binnen het VMBO wordt de VMBO-tl als het makkelijkst beoordeeld. Dit betekent uiteraard niet dat een VWO opleiding makkelijker is dan een HAVO opleiding, maar dat de VWO uitstroom minder moeite heeft gehad met de VWO studie dan de HAVO uitstroom met de HAVO studie. Eenzelfde patroon doet zich voor in de BOL, waar de niveau 4 opleidingen het vaakst als te makkelijk worden beoordeeld door de gediplomeerden. Wat niet uit de figuur blijkt is dat er maar weinig schoolverlaters van mening zijn dat de afgesloten opleiding te moeilijk is, namelijk $5 \%$. Bij de cijfers dient er echter rekening mee te worden gehouden dat het hier gaat om de mening van gediplomeerden en dat cursisten die de opleiding niet gehaald hebben buiten beschouwing zijn gelaten. Zij zullen ongetwijfeld een minder positief oordeel vellen over de moeilijkheidsgraad van de opleiding.

3. Voor deze aspecten zijn geen vergelijkbare gegevens van het WO beschikbaar. 
Figuur 3.1

Moeilijkheidsgraad van opleiding

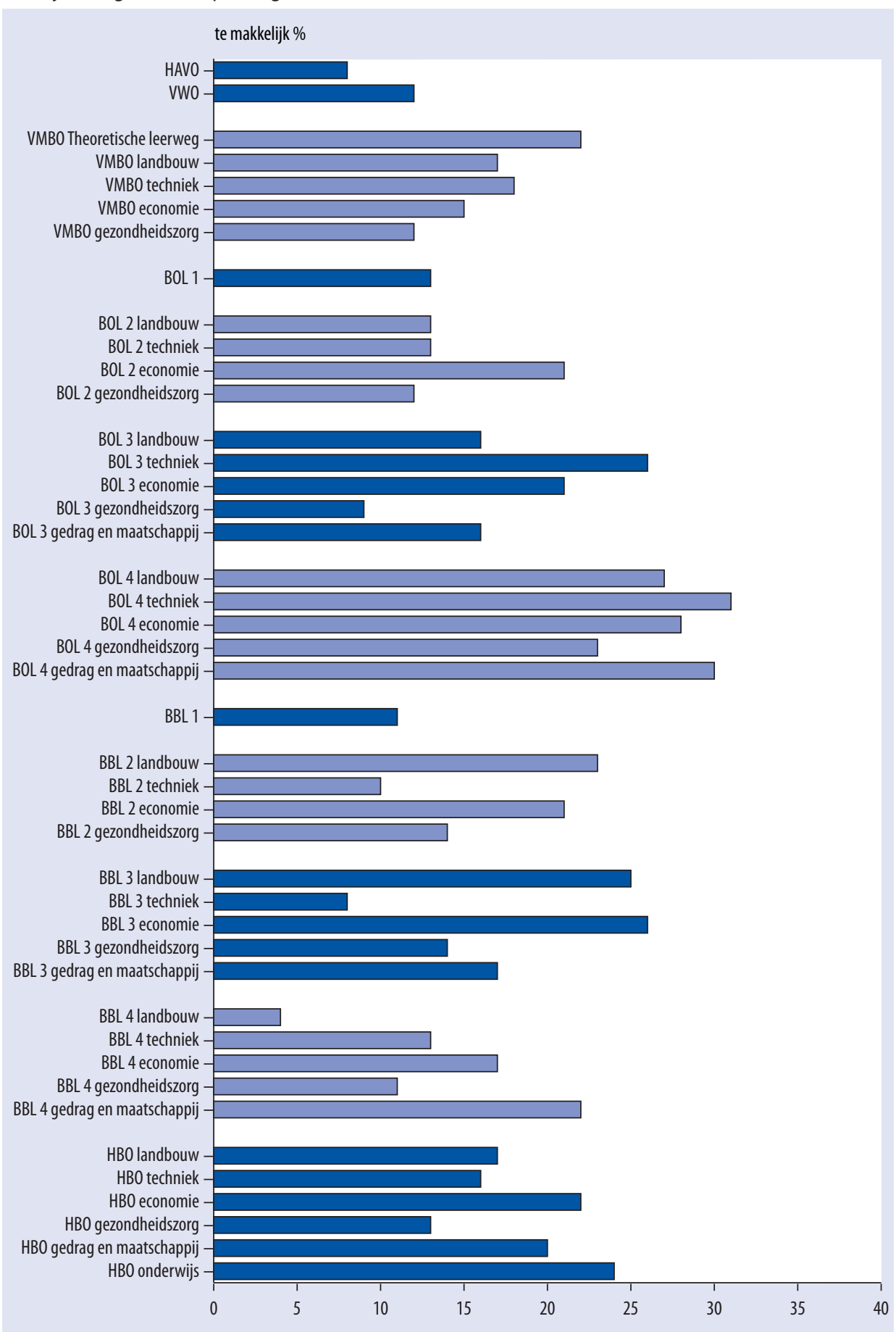

Bron: ROA (SIS) 


\section{Schoolverlateroordeel over de strengheid van beoordeling}

Voor het tweede aspect met betrekking tot de betrouwbaarheid van het selectieproces is an de schoolverlaters de volgende stelling voorgelegd: 'de docenten waren streng in de beoordeling van studenten'. Figuur 3.2 laat het percentage zien dat het met deze stelling (helemaal) eens is (antwoordcategorie 4 en 5 op een 5-puntschaal (van I 'helemaal mee oneens' naar 5 'helemaal mee eens').

Een op de vijf gediplomeerde schoolverlaters is het eens met de stelling dat de docenten streng waren in de beoordeling van de studenten. De schoolverlaters van het VO vinden dit het vaakst, wat in overeenstemming is met het lage percentage VO'ers dat de opleiding te gemakkelijk vindt. Binnen het $\mathrm{MBO}$ zijn de gediplomeerden uit het duale onderwijs het iets minder vaak eens met de stelling dan de gediplomeerden uit het voltijds $\mathrm{MBO}$ onderwijs. Wel zien we bij zowel de BOL als de BBL dat naarmate het opleidingsniveau stijgt het percentage schoolverlaters daalt dat de beoordeling streng vond. Het zijn met andere woorden vooral de zwakkere MBO'ers die de beoordeling streng vinden. Binnen het HBO kan worden geconstateerd dat afgestudeerden van het kunstonderwijs het vaakst vinden dat zij streng werden beoordeeld.

\section{Schoolverlateroordeel over het niveau van de opleiding}

Een andere indicator voor de selectiviteit van de opleiding gaat over de mate waarin de oud leerlingen hun gevolgde opleiding uitdagend qua niveau vinden. De stelling die hen is voorgelegd luidt: 'de opleiding was uitdagend met betrekking tot niveau'. Zij konden op een 5-puntschaal (van I 'helemaal mee oneens' naar 5 'helemaal mee eens') aangeven in hoeverre zij het met deze stelling eens waren. Hun antwoorden staan vermeld in figuur 3.3.

Van alle schoolverlaters is $32 \%$ het eens met de stelling dat de opleiding uitdagend qua niveau was (antwoordcategorie 4 en 5). Dit betekent overigens niet dat ruim tweederde van de schoolverlaters per definitie de opleiding helemaal niet uitdagend vindt. Een groot deel van hen zal het waarschijnlijk noch eens noch oneens met deze stelling zijn (zie tabel A4.3 van de Statistische Bijlage voor de percentages over de mate waarin men het oneens is met de genoemde stelling). De VMBO uitstroom is het minst tevreden over dit aspect: slechts I op de 4 oud leerlingen (26\%) vindt zijn of haar VMBO opleiding uitdagend qua niveau. Voor de theoretische leerweg geldt dit zelfs maar voor I van de vijf (22\%). Zoals uit figuur 3.3 blijkt zijn er per onderwijsniveau nog behoorlijke verschillen tussen de onderliggende onderwijssectoren (zie bijvoorbeeld het $\mathrm{HBO}$ waarbinnen de sector gezondheidszorg met $45 \%$ duidelijk het hoogste scoort wat het uitdagend niveau van de opleiding betreft). Zowel bij gediplomeerden van de BOL als bij gediplomeerden van de BBL kan worden geconstateerd dat hoe hoger het niveau van de gevolgde opleiding, hoe minder vaak de schoolverlaters zich uitgedaagd voelen. Het zijn met andere woorden vooral de 'betere' MBO'ers die niet alleen de beoordeling door docenten zwak vinden maar zich ook minder uitgedaagd voelen. De gevonden resultaten met betrekking tot deze indicator zijn overigens over het algemeen in overeenstemming met de resultaten van de vorige twee besproken aspecten van selectiviteit. 
Figuur 3.2

Strenge beoordeling van studenten

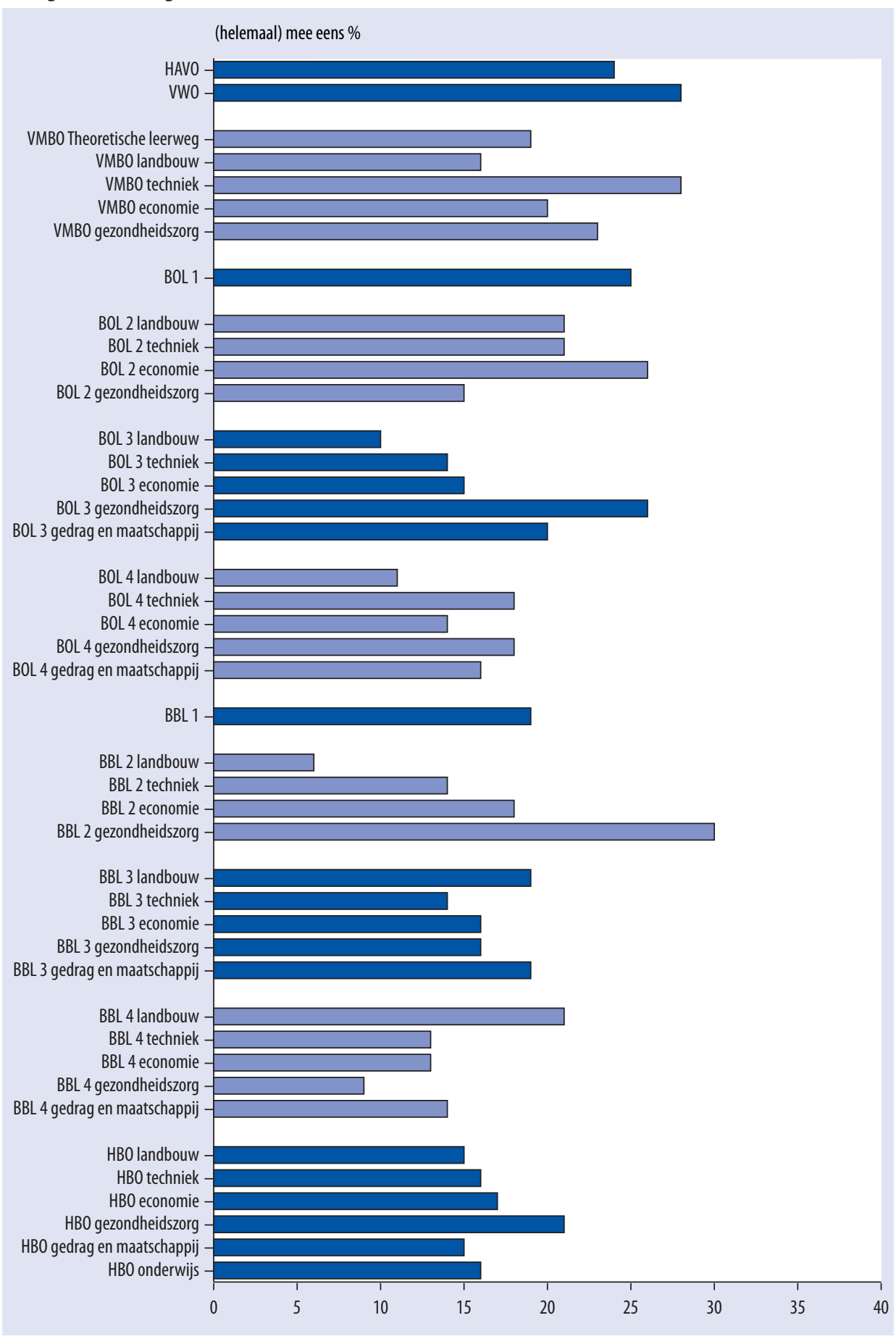

Bron: ROA (SIS) 
Figuur 3.3

Opleiding heeft uitdagend niveau

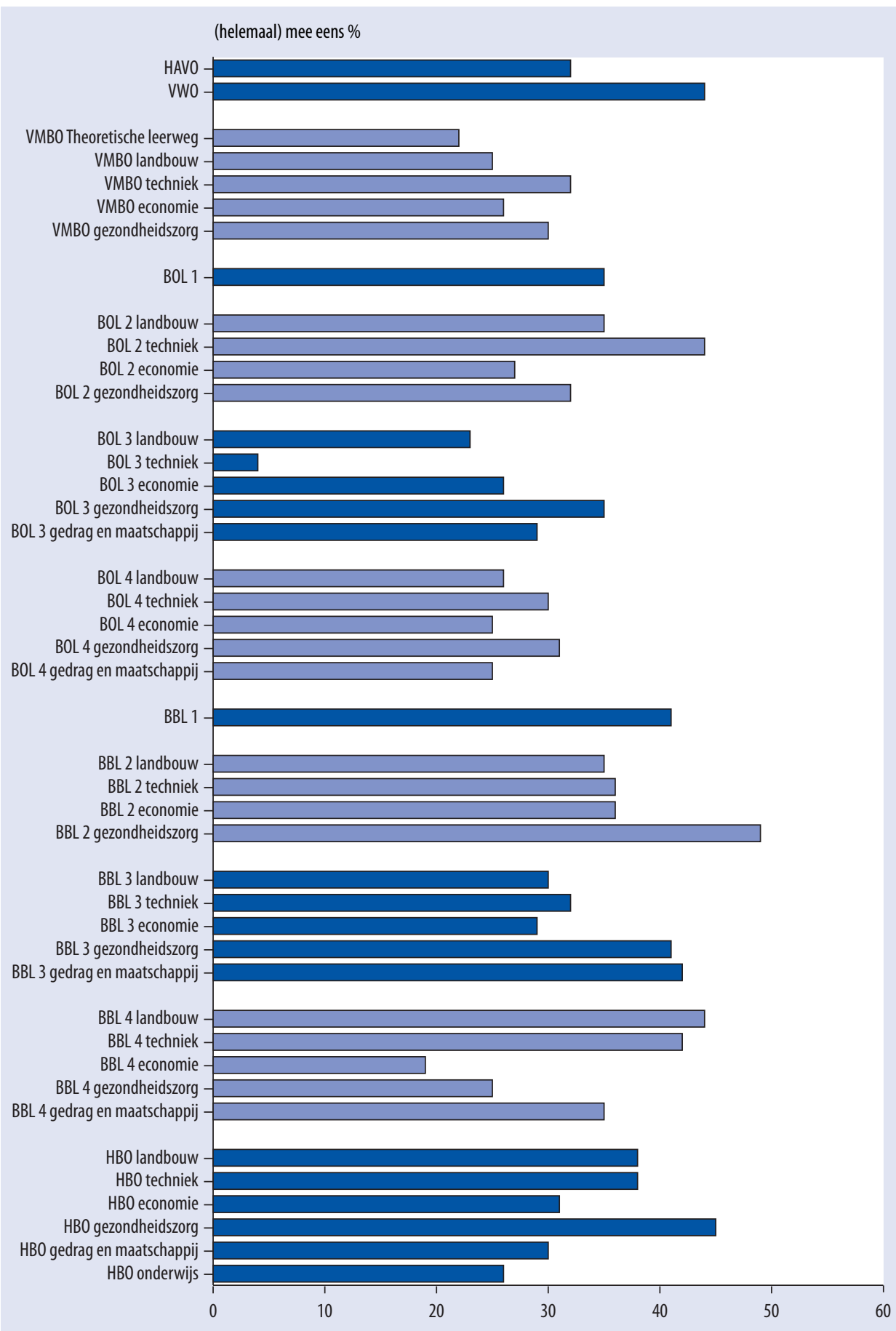

Bron: ROA (SIS) 
Aan de schoolverlaters is eveneens de volgende stelling voorgelegd 'de tentamens/opdrachten waren over het algemeen zeer pittig'. In figuur 3.4 zijn de resultaten met betrekking tot deze stelling per onderwijssoort weergegeven. Van alle schoolverlaters is een kwart $(26 \%)$ het met deze stelling (helemaal) eens (antwoordcategorie 4 en 5 op een 5-puntschaal van 'helemaal mee oneens' tot 'helemaal mee eens'). Afgestudeerde HBO'ers en schoolverlaters met een BOL diploma zijn het minst vaak de mening toegedaan dat hun opleiding relatief selectief was voor zover het de zwaarte van de examens en opdrachten betrof. Verder valt op dat examens van opleidingen in de sector gezondheidszorg door de bank genomen als zwaar worden ervaren. Binnen het $\mathrm{VO}$ worden de toetsen van de opleidingen op het hoogste niveau, het VWO, het vaakst als zeer pittig gezien. Dit in tegenstelling tot de BOL. Hier kan namelijk worden geconstateerd dat hoe hoger het niveau van de gevolgde opleiding, hoe minder vaak de schoolverlaters de toetsen zwaar vonden.

\section{Schoolverlateroordeel over inhoud van toetsen}

Niet alleen de zwaarte van de examens is van belang maar ook wat getoetst wordt. Gaat het om het kunnen reproduceren van feiten of wordt er ook op inzicht getoetst? De laatste indicator voor de betrouwbaarheid van de selectie gaat dan ook over de vraag in hoeverre men vindt dat er in de opleiding voldoende getoetst is op inzicht (zie figuur 3.5). Daartoe is aan de schoolverlaters gevraagd om op een 5 -puntschaal (van I 'helemaal mee oneens' naar 5 'helemaal mee eens') aan te geven in hoeverre men het eens is met de uitspraak dat in de opleiding voldoende werd getoetst op inzicht.

In figuur 3.5 staan de cijfers per onderwijssoort weergegeven. Gemiddeld vinden vier van de tien schoolverlaters dat er voldoende wordt getoetst op inzicht (antwoordcategorie 4 en 5). Dit varieert van een derde (33\%) onder HBO'ers (vooral HBO'ers uit het pedagogisch onderwijs vinden niet vaak dat er voldoende op inzicht wordt getoetst) tot meer dan de helft (56\%) van de VWO'ers. Binnen zowel de BOL als de BBL valt verder op dat de schoolverlaters met een niveau I of 2 diploma vaker van mening zijn dat er tijdens hun opleiding voldoende op inzicht is getoetst dan hun collega schoolverlaters met een niveau 3 of 4 diploma. 
Figuur 3.4

Examens/opdrachten over het algemeen pittig

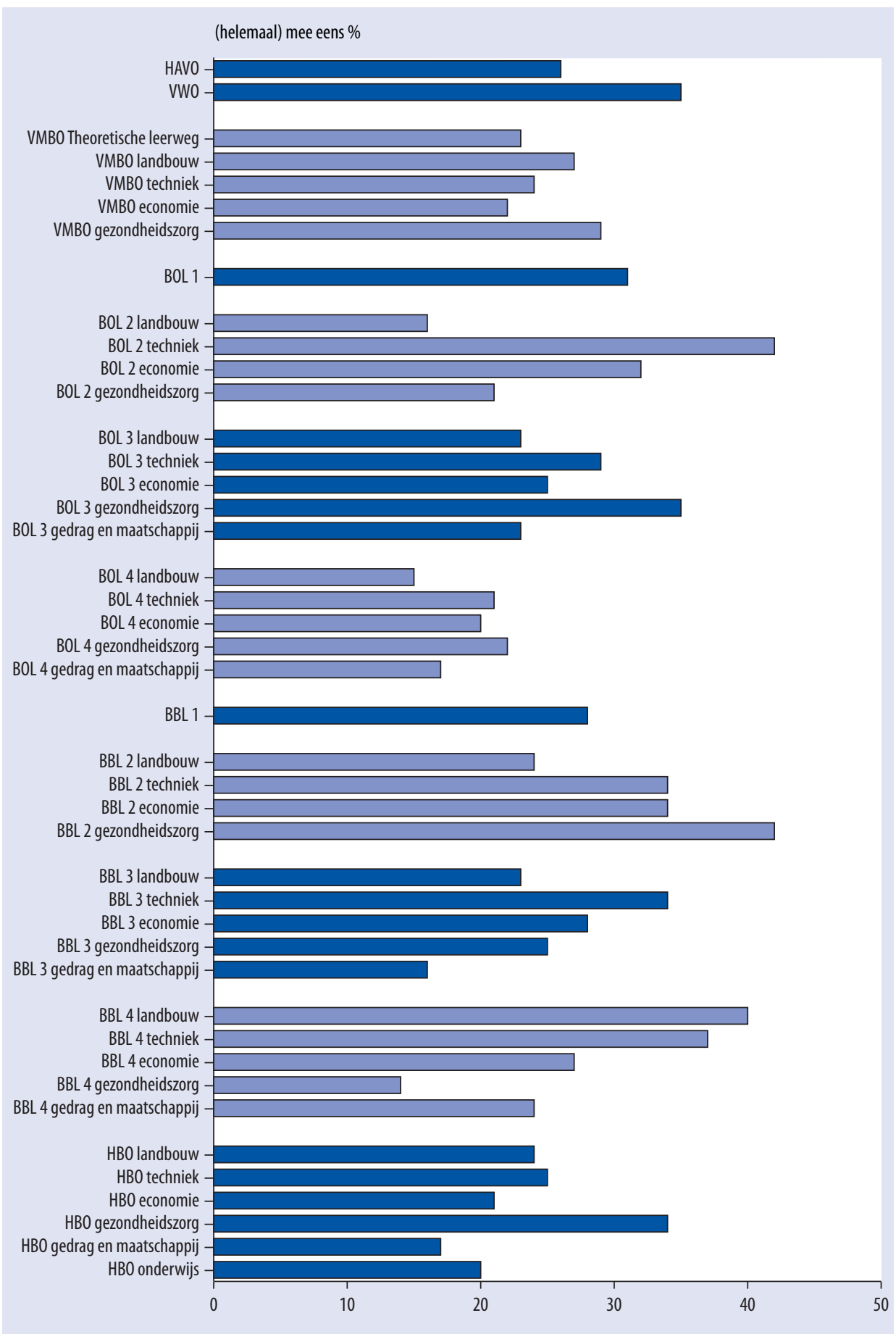

Bron: ROA (SIS) 
Figuur 3.5

Toetsen op inzicht

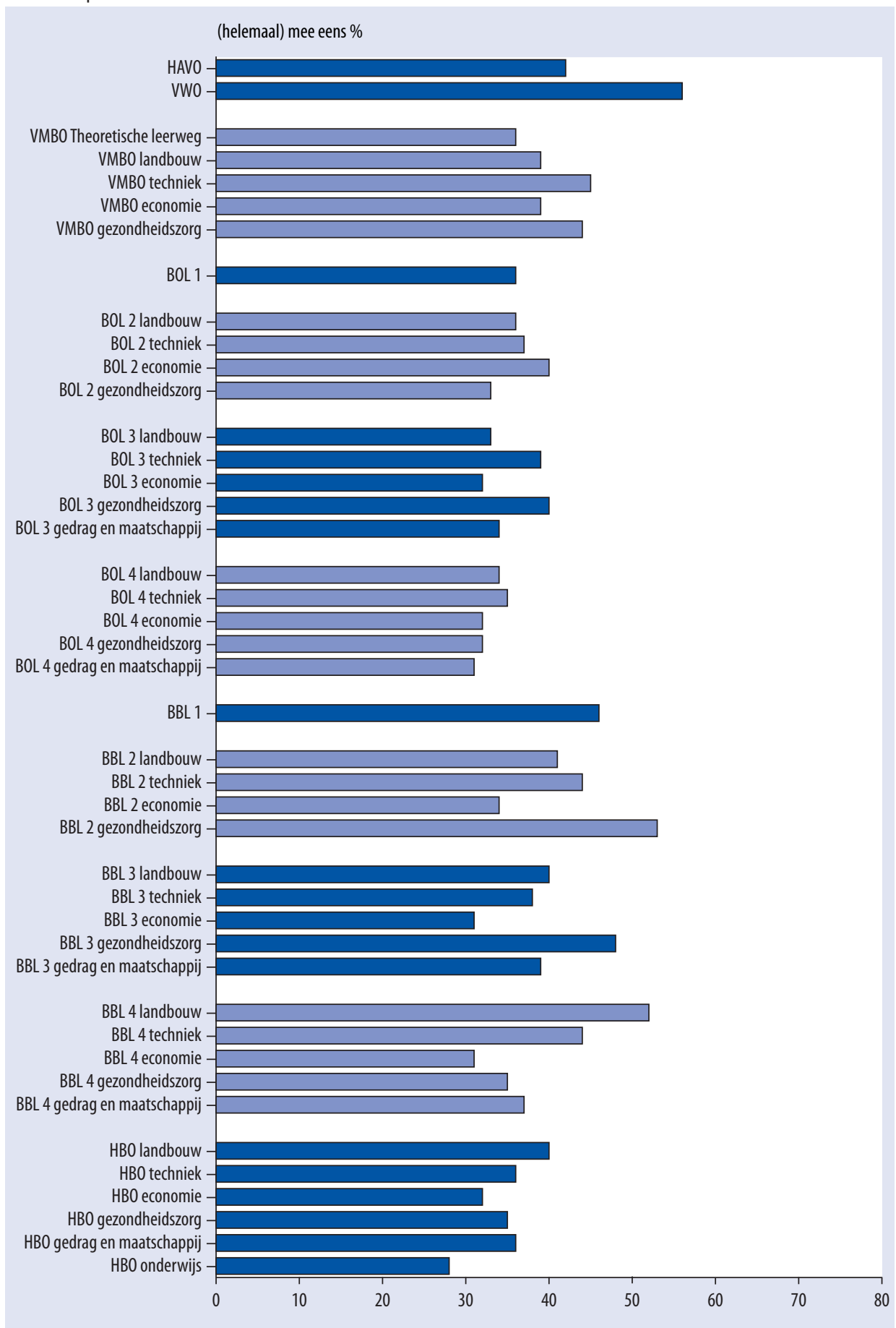

Bron: ROA (SIS) 


\section{Kwalificerende vervolgtrajecten}

$\mathrm{Al}$ voor het behalen van het diploma staan schoolverlaters voor een belangrijke keuze. Men kan er voor kiezen om toe te treden tot de arbeidsmarkt of er voor kiezen om verder onderwijs te gaan volgen. Omdat deze vervolgtrajecten verschillend van karakter zijn, worden deze groepen apart behandeld om de allocatiefunctie en het rendement in kaart te brengen. In dit hoofdstuk gaat het om de uitstroom die kiest voor een vervolgstudie. Hierbij gaat het zowel om degenen die de studie vervolgen in een volledige dagopleiding als degenen die werken en leren combineren via een duale opleiding. Aangezien er vanuit de BBL weinig doorstroom is naar vervolgonderwijs zullen de cijfers van de BBL in dit hoofdstuk niet nader naar sector gespecificeerd worden.

\section{Allocatie}

De doorstroom naar vervolgonderwijs verschilt per onderwijsniveau. Daarom wordt eerst de doorstroom binnen het onderwijs in kaart gebracht (figuur 4.I en 4.2). In figuur 4.I staat een overzicht van de kwalificerende vervolgtrajecten van de gediplomeerde schoolverlaters uit het onderzoek. De figuur vermeldt het procentuele aandeel van gediplomeerde schoolverlaters per onderwijssoort dat sinds het afstuderen naar een bepaald kwalificerend vervolgtraject is gegaan evenals het percentage dat niet voor een kwalificerend vervolgtraject heeft gekozen. Vanwege de duidelijkheid zijn in de figuur de BOL en BBL niveaus samengevoegd en zijn alleen vervolgtrajecten met een aandeel van minstens $5 \%$ opgenomen.

Vanuit het AVO stroomt het overgrote deel van de gediplomeerde schoolverlaters door naar een vervolgopleiding. Van de totale groep HAVO respondenten is $83 \%$ doorgestroomd naar een HBO opleiding. Van de VWO'ers is I3\% naar het HBO gegaan, terwijl het merendeel $(77 \%)$ voor een studie in het WO heeft gekozen. Van de gediplomeerde VMBO respondenten gaat $5 \%$ niet verder met een vervolgopleiding. Deze $5 \%$ verlaat het onderwijs dus zonder een startkwalificatie verkregen te hebben. Dit wil overigens niet zeggen dat deze schoolverlaters voorgoed verloren zijn voor het onderwijs: ze zijn alleen niet direct na het behalen van hun VMBO diploma doorgestroomd naar een vervolgstudie.

Van de BOL respondenten geeft iets meer dan de helft (53\%) aan begonnen te zijn aan een nieuwe opleiding. Bij de BBL is dit een kwart (26\%). Van de totale groep BOL gediplomeerden kiest ruim een kwart voor een studie in het $\mathrm{HBO}$, terwijl $17 \%$ binnen de BOL blijft verder leren. Van de BBL'ers die verder leren blijft het merendeel een duaal traject volgen op MBO niveau. Van de HBO'ers gaat ruim een derde verder met een opleiding, waarvan de meesten met een universitaire opleiding. Het gaan volgen van een nieuwe studie wil overigens niet automatisch zeggen dat men zich niet aanbiedt op de arbeidsmarkt. Doorstroom vanuit het WO naar kwalificerend vervolgonderwijs ( $31 \%$ ) betreft doorgaans doorstroom naar postdoctorale beroepsopleidingen en wordt daarom niet apart in figuur 4.I vermeld. 


\begin{abstract}
Box 4.1: School-ex Programma
De groep schoolverlaters waar dit hoofdstuk op is gebaseerd, heeft tijdens hun laatste studiejaar (2007-2008) of vlak erna een beslissing genomen over het al dan niet gaan volgen van een vervolgopleiding. De vraag is of schoolverlaters bij hun keuze om eventueel door te leren rekening houden met de economische situatie in het algemeen en die op de arbeidsmarkt in het bijzonder. De studiekeuze van deze groep schoolverlaters is echter nog gemaakt in de tijd voordat er sprake was van een economische crisis. Of, en zo ja in hoeverre de economische situatie van invloed is op het studiekeuze gedrag is het centrale onderwerp geweest in het ROA rapport MBO-diploma in tijden van crisis. Doorleren of werk zoeken? (Meng, Huijgen, Ramaekers, 2010). Hieruit is naar voren gekomen dat van de MBO'ers die voorjaar 2009 (dus tijdens de economische crisis) hun diploma hebben behaald $15 \%$ zich door activiteiten van scholen in het kader van het School-ex Programma heeft laten beïnvloeden en a) alsnog verder is gaan leren (12\%-punt) of b) zijn of haar voorkeur voor een bepaalde vervolgopleiding heeft bijgesteld (3\%-punt).
\end{abstract}

\title{
Figuur 4.1
}

Kwalificerende vervolgtrajecten na het verlaten van de opleiding

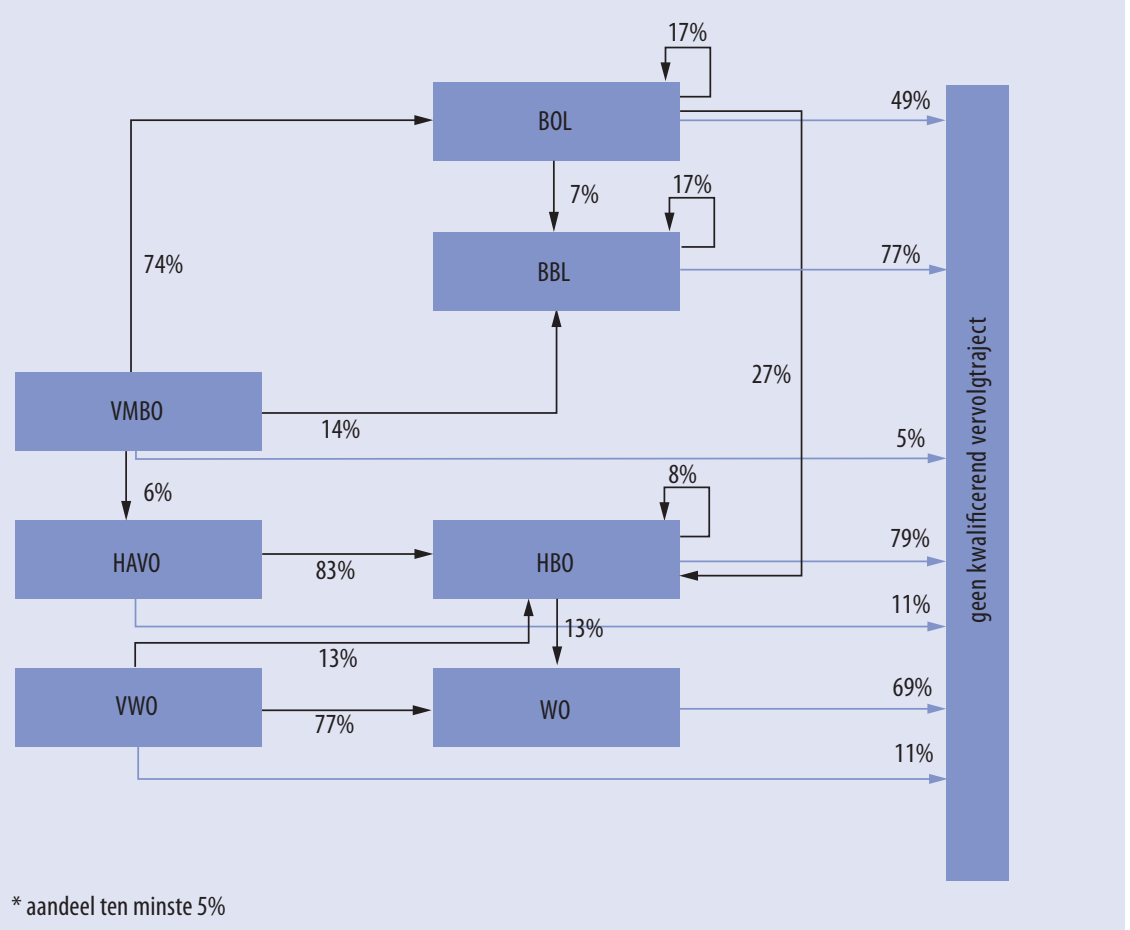

Bron: ROA (SIS); VNSU/IVA, 2009

Mede met het oog op het al dan niet verkrijgen van een startkwalificatie is de doorstroom van het VMBO naar het MBO een belangrijke peiler in het Nederlandse onderwijsstelsel. Daarbij speelt niet alleen de vraag of men voor een kwalificerend vervolgtraject kiest een belangrijke rol, maar ook, indien dit vervolgtraject in het $\mathrm{MBO}$ plaatsvindt, voor welk niveau men kiest. Figuur 4.2 laat voor de VMBO-schoolverlaters het percentage zien dat voor een bepaald niveau in het MBO heeft gekozen. Omdat de doorstroom naar een bepaald MBO niveau minder aan de opleidingssector gebonden is maar meer aan het niveau onderscheiden we daarbij niet de sectoren in het VMBO maar de leerwegen. Omdat in figuur 4.2 alleen 
kwalificerende $\mathrm{MBO}$-vervolgtrajecten met een aandeel van tenminste $5 \%$ staan vermeld, tellen de percentages niet op tot $100 \%$.

De gediplomeerden van de VMBO basisberoepsgerichte leerweg gaan het minst vaak verder met een nieuwe opleiding: IO\% van hen gaat geen vervolgstudie doen. Bij de uitstroom van de andere leerwegen liggen deze percentages aanzienlijk lager. Voor alle vier leerwegen geldt overigens dat in vergelijking met het vorig meetjaar het percentage dat geen kwalificerend vervolgtraject gaat volgen gedaald is. Van de verder lerende VMBO'ers met een basisberoepsgerichte opleiding, het laagste VMBO niveau, gaat de helft een BOL niveau 2 opleiding volgen, terwijl $22 \%$ kiest voor een niveau 2 opleiding in de BBL. De gediplomeerden van de kaderberoepsgerichte leerwegen en de gemengde leerwegen vinden in overgrote meerderheid hun weg naar BOL niveau 3 en 4 opleidingen. Dit geldt ook voor de mensen die een VMBO-tl diploma op zak hebben.

\section{Figuur 4.2}

Kwalificerende MBO-vervolgtrajecten na het verlaten van de VMBO-opleiding

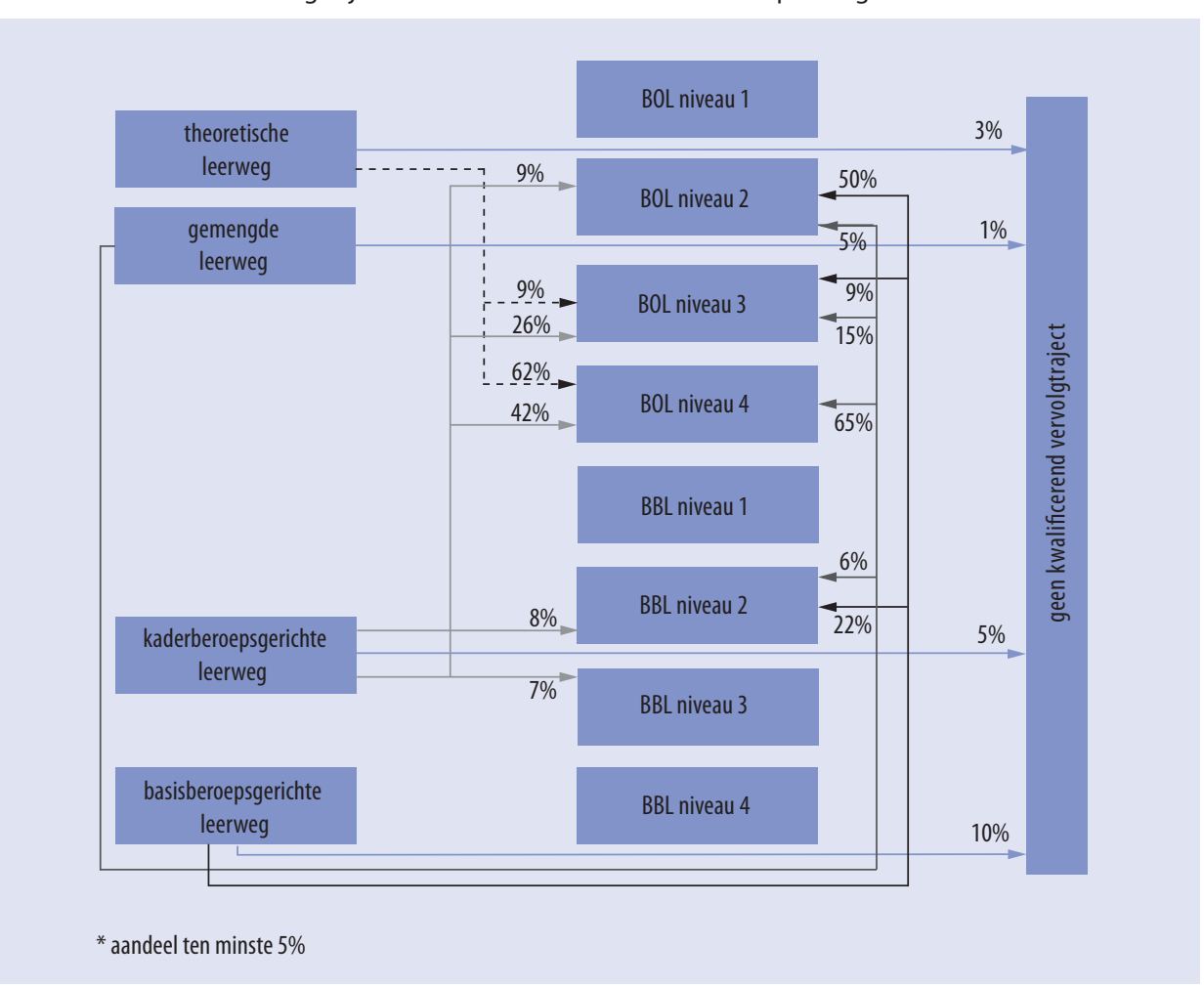

Bron: ROA (SIS)

Voor onderwijssectoren is het daarnaast relevant om te weten in hoeverre de gekozen vervolgtrajecten binnen dezelfde opleidingsrichting liggen. Een onderwijsinstelling dient rekening te houden met de mate waarin bijvoorbeeld de instroom van een bepaalde opleiding uit dezelfde sector afkomstig is. Voor bijvoorbeeld een BOL techniek opleiding is het belangrijk om te weten in hoeverre de beginnende studenten een technische achtergrond hebben. Iedere 
opleiding vormt daarnaast in beginsel een voorbereiding op een eventuele vervolgopleiding, en dient er dus ook aan de uitstroomzijde rekening mee te houden hoe groot de doorstroom naar verwante opleidingen is.

Figuur 4.3 laat zien in hoeverre de verder lerende schoolverlaters kiezen voor een vervolgopleiding in dezelfde opleidingsrichting als de afgesloten opleiding. Dit varieert van de helft $(51 \%)$ van de verder lerende HBO'ers tot 63\% van de verder lerende MBO'ers. In het VMBO komt doorstroom naar een verwante opleidingsrichting het vaakst voor bij de sector techniek en in het $\mathrm{HBO}$ bij de sector taal en cultuur.

\section{Figuur 4.3}

Doorstroom naar verwante opleidingen per opleidingssector in het beroepsonderwijs

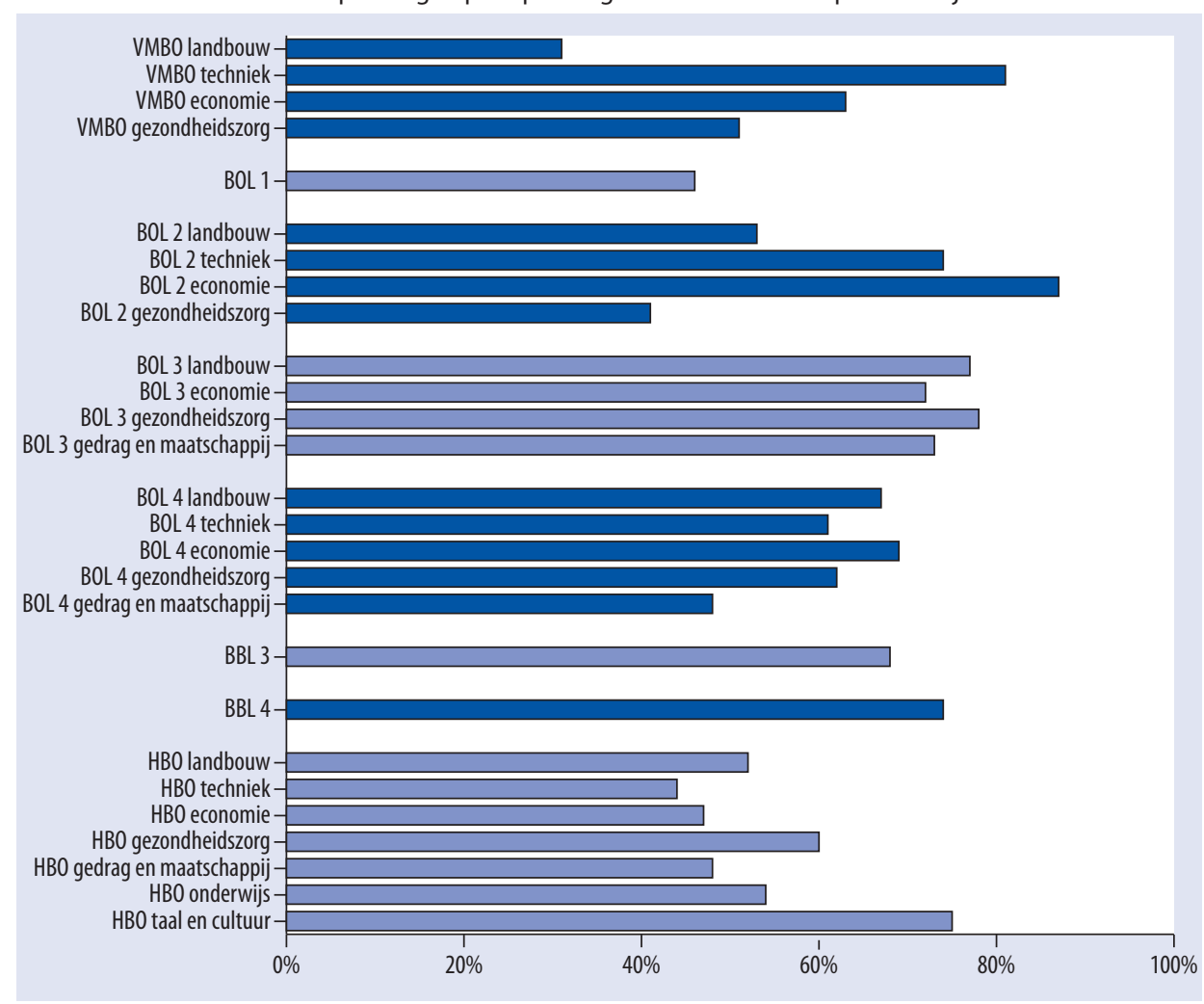

Bron: ROA (SIS)

Aan de verder lerende schoolverlaters is gevraagd om aan te geven wat ze vinden van de aansluiting tussen hun gevolgde opleiding en hun vervolgstudie. Dit omdat het doorstromen naar een vervolgopleiding in dezelfde onderwijssector niet automatisch hoeft te betekenen dat de aansluiting tussen de gevolgde opleiding en de vervolgopleiding goed is. Zo hoeft de aansluiting tussen twee opleidingen uit verschillende onderwijssectoren ook niet per definitie slecht te zijn. In figuur 4.4 staan de percentages van de verder lerende schoolverlaters vermeld die de aansluiting tussen de afgeronde- en de vervolgopleiding goed of voldoende vinden. Vanwege de geringe doorstroom vanuit het hoger onderwijs naar regulier vervolgonderwijs 
en het feit dat de allocatiefunctie van het hoger onderwijs niet gericht is op vervolgonderwijs is de betreffende vraag niet aan $\mathrm{HBO}$ en WO afgestudeerden voorgelegd.

Bijna driekwart van alle schoolverlaters die een vervolgopleiding zijn gaan volgen vindt de aansluiting tussen de gevolgde opleiding en de vervolgopleiding redelijk tot goed. Binnen het AVO vinden de VWO schoolverlaters deze aansluiting het vaakst redelijk tot goed, en binnen het $\mathrm{VMBO}$ en de BOL 2 de schoolverlaters met een economie opleiding.

\section{Figuur 4.4}

Percentage van de verder lerende schoolverlaters dat de aansluiting tussen de gevolgde opleiding en de vervolgopleiding voldoende of goed vindt, per opleidingssector

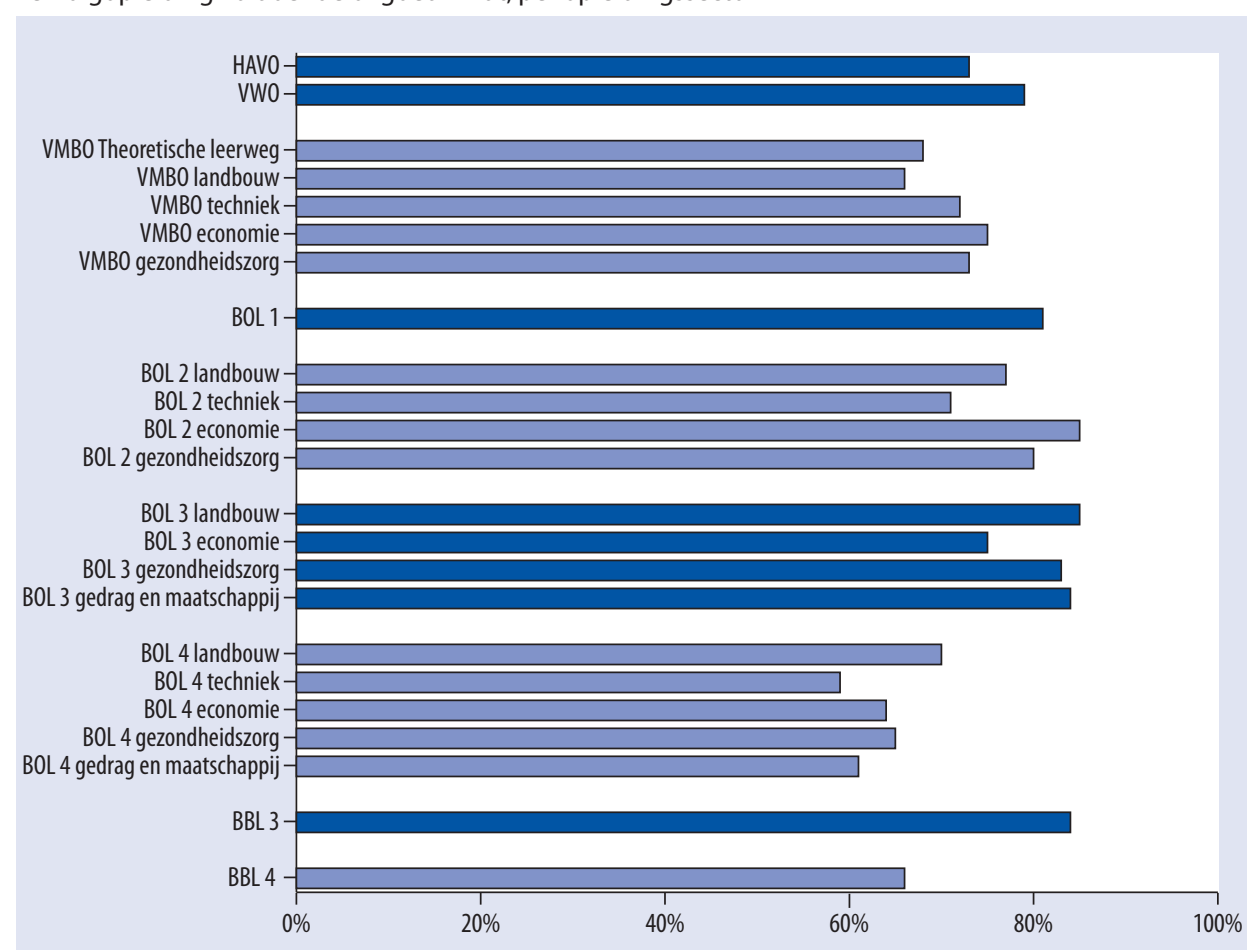

Bron: ROA (SIS)

\section{Rendement}

Zoals al eerder ter sprake is gekomen, is één van de functies van onderwijs het voorbereiden van leerlingen op een eventueel vervolgtraject in het onderwijs. Om het rendement hiervan te meten, kijken we naar het percentage dat op het moment van enquêteren (ongeveer anderhalf jaar na het behalen van het diploma) in de vervolgopleiding bevorderd is naar het tweede leerjaar/studiejaar en het percentage dat de vervolgopleiding op het moment van de enquête weer heeft verlaten of van studie is gewisseld. Een grote uitval in vervolgonderwijs kan duiden op een gebrekkige aansluiting. Deze gebrekkige aansluiting kan meerdere oorzaken hebben. Zo kan het curriculum van één of beide opleidingen niet passend (genoeg) zijn. Daarnaast kan sprake zijn van een gebrekkige studiekeuzevoorlichting of kan de arbeidsmarkt veel mogelijkheden bieden. 
In figuur 4.5 staat het aandeel verder lerende schoolverlaters dat de vervolgopleiding voortijdig verlaten heeft zonder direct aan een nieuwe studie begonnen te zijn (de netto uitval) alsmede het aandeel dat van studie gewisseld is. In de figuur staat eveneens welk deel van de verder lerende schoolverlaters bevorderd is naar het tweede leerjaar en met andere woorden dus succesvol bezig is met de vervolgstudie.

In totaal geeft $13 \%$ van de verder lerende schoolverlaters aan gestopt te zijn met de aanvankelijk gekozen vervolgopleiding. Van alle onderwijsniveaus stoppen de havisten met 22\% het vaakst voortijdig met de vervolgopleiding, gevolgd door VWO'ers (20\%). Bij de schoolverlaters van vrijwel alle andere onderwijsniveaus liggen deze percentages aanzienlijk lager. Bij het $\mathrm{VMBO}$ en het MBO-BOL is dit II\%, bij het MBO-BBL 8\% en bij het $\mathrm{HBO} 7 \%$. Wellicht nog belangrijker dan het percentage 'afhakers' vlak na aanvang van de vervolgstudie is het percentage van hen dat ook niet aan een andere studie begonnen is. Met andere woorden welk deel van deze uitvallers zijn studiewisselaars en welk deel heeft op het enquêtemoment daadwerkelijk het onderwijs verlaten? Het gaat dus niet alleen om de hoogte van de bruto uitval maar met name om de netto uitval. Van de $13 \%$ met de vervolgopleiding gestopte schoolverlaters is gelukkig gemiddeld zo'n 9\%-punt studiewisselaar, dat wil zeggen iemand die nog niet uit het vervolgonderwijs verdwijnt maar in eerste instantie een verkeerde studiekeuze lijkt te hebben gemaakt. Er is relatief het vaakst sprake van echte uitval bij doorstromers vanuit het HBO. De relatief grote uitval onder de VO'ers (2I\%) blijkt voor een groot deel uit studiewisselaars te bestaan: de netto uitval in deze groep blijkt uiteindelijk $3 \%$ te zijn.

In hoeverre de groep die niet voortijdig met de opleiding stopt succesvol is kan worden afgemeten aan de hand van de vraag of men al dan niet bevorderd is naar het tweede leerjaar. Omdat deze vraag minder relevant is voor afgestudeerden uit het hoger onderwijs is deze vraag niet aan hen voorgelegd. Schoolverlaters van het voortgezet onderwijs doen het wat dit aspect betreft het beste. Gemiddeld is $95 \%$ van hen bevorderd naar het tweede leerjaar. Van de andere onderwijsniveaus hebben de schoolverlaters van BOL niveau 3 de meeste moeite met hun vervolgstudie: van hen geeft $80 \%$ aan bevorderd te zijn naar leerjaar 2 .

Op basis van de schoolverlatersonderzoeken is het eveneens mogelijk om te kijken welke vervolgopleidingen de grootste slaagkans en de grootste uitval hebben. De cijfers in figuur 4.6 geven hiervan een indicatie. In tegenstelling tot alle andere figuren in dit hoofdstuk zijn de cijfers in figuur 4.6 niet gepresenteerd naar de sector van de afgesloten opleiding maar naar die van de vervolgopleiding. Ook hier wordt een onderscheid gemaakt tussen de netto uitval en het percentage studiewisselaars. Hoewel het bijvoorbeeld uit kostenoverwegingen voor een individuele onderwijssector van belang is om geen hoge uitval te hebben, is het op macroniveau relevant hoeveel van deze uitval voor het onderwijs verloren gaat. Omdat de instroom in niveau I opleidingen van het $\mathrm{MBO}$ niet alleen vanuit de gediplomeerde uitstroom van het VMBO plaatsvindt maar ook voor een belangrijk deel betrekking heeft op ongediplomeerde uitstroom van het $\mathrm{VMBO}$, kunnen we op basis van onze cijfers geen representatieve schatting geven van het rendement in deze opleidingen. Deze zijn dan ook niet in figuur 4.6 opgenomen. De vraag over het bevorderd zijn naar het tweede leerjaar van de vervolgopleiding is ook niet gevraagd aan de afgestudeerden uit het hoger onderwijs. Het rendement in het hoger onderwijs heeft dan ook alleen betrekking op de doorstroom vanuit VWO, HAVO en MBO. 


\section{Figuur 4.5}

Percentage van de verder lerende schoolverlaters dat bevorderd is naar het tweede leerjaar/studiejaar, percentage dat de vervolgopleiding voortijdig heeft verlaten (netto uitval) en het percentage dat andere opleiding is gaan volgen (studiewisselaars)

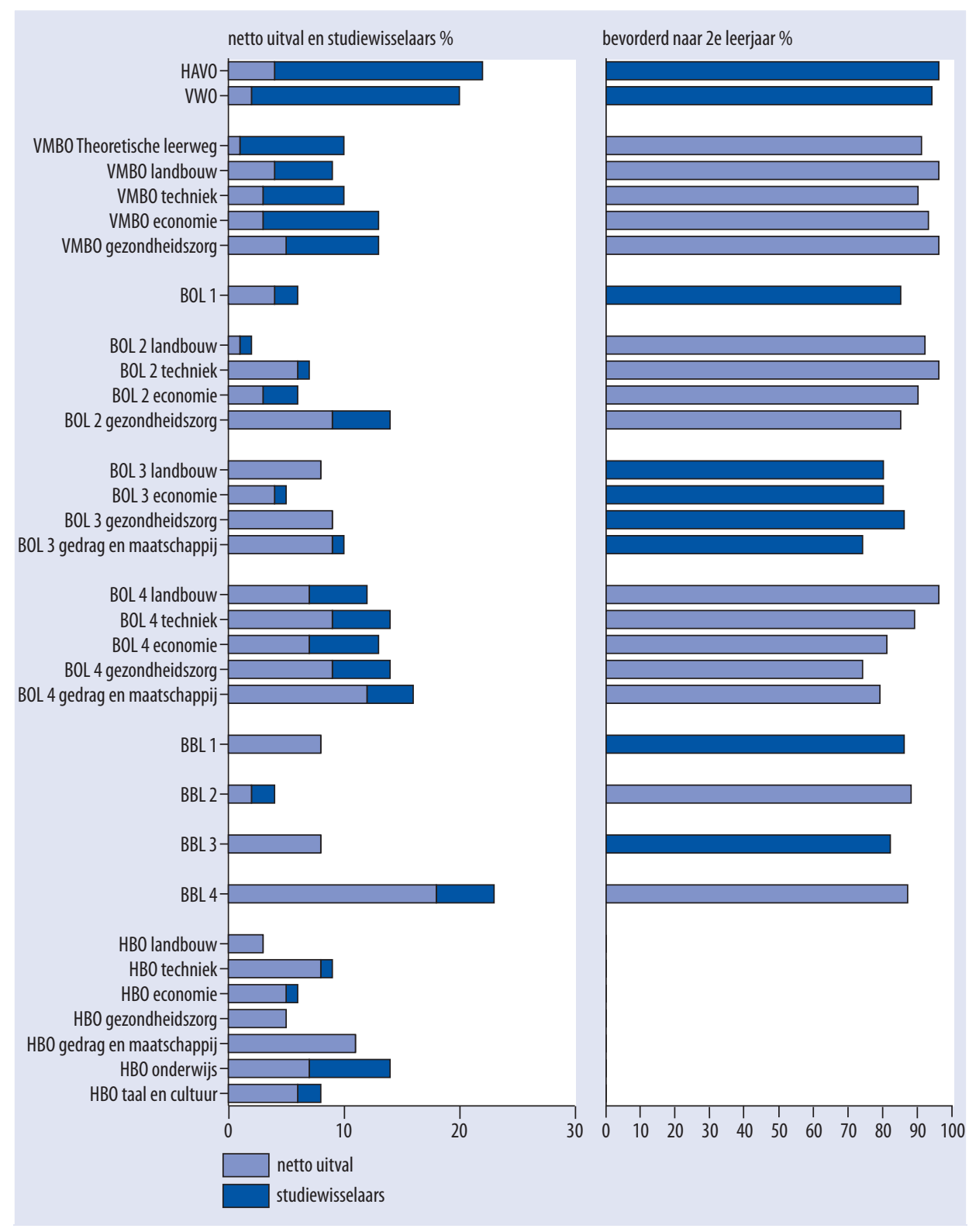

Bron: ROA (SIS) 
Uit figuur 4.6 blijkt dat vooral in het hoger onderwijs het percentage dat stopt met de opleiding vrij hoog is (HBO: I8\%; WO: I8\%). De hoge percentage uitvallers in het hoger onderwijs verklaren waarom onder de VO'ers het percentage dat met de vervolgopleiding stopt zo hoog is (21\%). Van de havisten stroomt $83 \%$ in eerste instantie door naar het $\mathrm{HBO}$, terwijl $77 \%$ van de VWO'ers doorstroomt naar het WO. Binnen het MBO blijken met name bij de BBL niveau 4 opleidingen weinig mensen te zijn die met de opleiding stoppen. Wanneer rekening gehouden wordt met het percentage studiewisselaars zijn de verschillen over het gehele onderwijsveld kleiner. Wanneer gekeken wordt welk deel van de verder lerende schoolverlaters bevorderd is naar het tweede leerjaar doet ook nu het hoger beroepsonderwijs het minder goed. Over alle onderwijsniveaus zijn de verschillen relatief klein. De BOL niveau 3 opleidingen kennen daarbij het laagste percentage niet bevorderden $(5 \%)$.

\section{Tevredenheid achteraf}

Figuur 4.7 toont het percentage verder lerende schoolverlaters dat de afgesloten opleiding, achteraf bezien, opnieuw zou volgen. Hierbij gaat het alleen om schoolverlaters van het MBO en het hoger onderwijs. Deze schoolverlaters hebben gekozen voor een vervolgstudie maar hadden met hun al behaalde kwalificatie ook naar de arbeidsmarkt kunnen gaan. Formeel gezien geldt dit niet voor de $\mathrm{MBO}$ niveau I opleidingen, maar de cijfers zijn voor de volledigheid wel in de figuur opgenomen. Daarnaast is er bij schoolverlaters van het voortgezet onderwijs vanwege de leerplicht minder sprake van een echte keuze. Er dient opgemerkt te worden dat het, evenals in alle andere figuren in dit hoofdstuk, gaat om het oordeel van de gediplomeerde uitstromers. De niet gediplomeerden zullen ongetwijfeld minder positief in hun oordeel zijn.

Gemiddeld zouden acht van de tien schoolverlaters achteraf bezien opnieuw kiezen voor de door hen afgeronde opleiding. De WO afgestudeerden en BBL schoolverlaters zijn hierbij het meest tevreden. Binnen de BOL scoren de niveau 4 opleidingen het beste wat de tevredenheid over de gekozen opleiding betreft, en binnen de BBL de niveau 2 opleidingen. Evenals verleden jaar zijn de afgestudeerde leraren binnen het $\mathrm{HBO}$ het meest tevreden. Aangezien zij bij aanvang van de studie een duidelijk beeld hebben van het uiteindelijke beroep dat ze zullen gaan uitoefenen, is het niet verwonderlijk dat degenen die de opleiding helemaal afmaken tevreden zijn over de door hen gemaakte studiekeuze. 


\section{Figuur 4.6}

Percentage van de verder lerende schoolverlaters dat bevorderd is naar het tweede leerjaar/studiejaar, percentage dat de vervolgopleiding voortijdig heeft verlaten (netto uitval) en het percentage dat andere opleiding is gaan volgen (studiewisselaars) naar sector vervolgopleiding

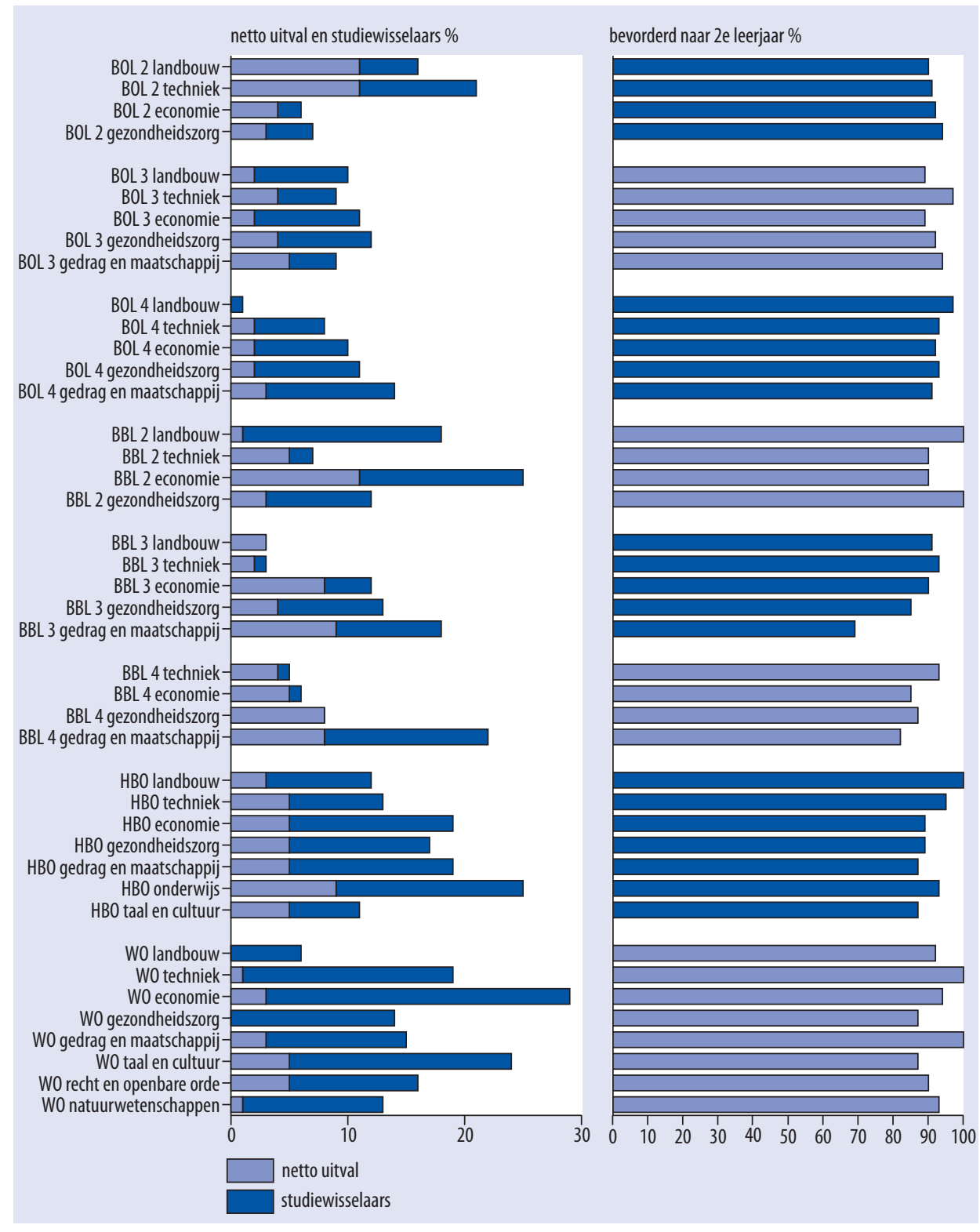

Bron: ROA (SIS) 


\section{Figuur 4.7}

Percentage verder lerende schoolverlaters dat de afgesloten opleiding achteraf bezien opnieuw zou volgen, per opleidingssector

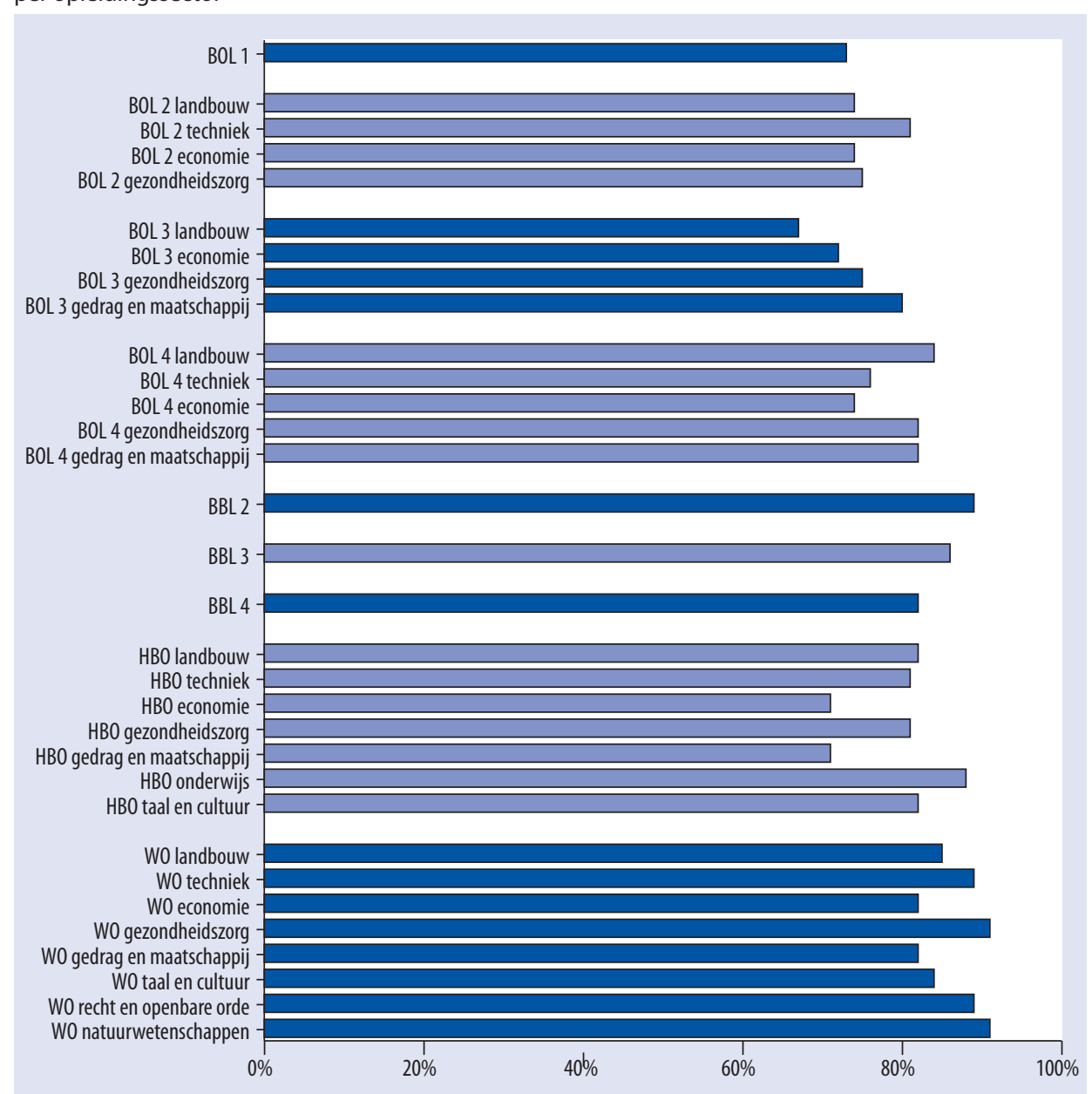

Bron: ROA (SIS); VSNU/IVA, 2009 


\section{Intrede op de arbeidsmarkt}

Vooral het middelbaar en hoger onderwijs worden geacht leerlingen kennis en vaardigheden bij te brengen die ze nodig hebben bij het betreden van de arbeidsmarkt. Terwijl het vorige hoofdstuk zich richtte op de verder lerende schoolverlaters, staat in dit hoofdstuk de groep centraal die de arbeidsmarkt betreden heeft. Aan de hand van de oordelen van de betaald werkende schoolverlaters en hun baankenmerken wordt een indicatie verkregen over de allocatie op de arbeidsmarkt en over de opbrengsten voor individuele schoolverlaters op de arbeidsmarkt. De groep schoolverlaters die daarbij centraal staat, bestaat uit gediplomeerden die op het moment van bevraging tot de beroepsbevolking worden gerekend. Daarbij is als voorwaarde gesteld dat hun maatschappelijke positie niet scholier of student is. Deze laatste voorwaarde geldt om te voorkomen dat studenten met bijbaantjes in de analyses terecht komen. Opgemerkt zij dat MBO'ers die verder leren en werken combineren in de BBL worden gezien als aanbieders op de arbeidsmarkt én als doorleerders.

De schoolverlaters van het HAVO en VWO worden in dit hoofdstuk niet meegenomen. Dit omdat slechts een klein deel van hen doorstroomt naar de arbeidsmarkt en het AVO feitelijk ook niet bedoeld is als voorbereidend onderwijs voor de arbeidsmarkt. De gegevens die nodig zijn voor dit hoofdstuk zijn daarnaast voor een groot deel niet beschikbaar voor deze groep omdat de AVO vragenlijst meer gericht is op het vervolgtraject in het onderwijs. Schoolverlaters die slagen voor het VMBO examen en schoolverlaters die slagen voor een BOL of BBL niveau I examen zijn weliswaar formeel gediplomeerd maar vallen onder de definitie $^{4}$ van de voortijdige schoolverlaters indien ze doorstromen naar de arbeidsmarkt. Omdat ze niet beschikken over een startkwalificatie worden ze niet geacht de arbeidsmarkt te betreden. Omdat echter een niet onbelangrijk deel wel doorstroomt naar de arbeidsmarkt worden ze in de rest van dit hoofdstuk wel meegenomen.

\subsection{Allocatie}

In eerste instantie valt of staat een succesvolle intrede op de arbeidsmarkt met het al dan niet vinden van een (vaste) baan. De feitelijke werkzaamheden, verantwoordelijkheden en de inhoud van de functie bepalen in hoeverre iemand de mogelijkheid heeft om zijn of haar kennis en vaardigheden te benutten. Daarnaast bepalen de inhoud en het niveau van het werk mede de financiële vergoeding die hier tegenover staat. Dus niet alleen de kans op werk en werkzekerheid maar ook de kwaliteit van het werk bepalen in hoeverre de overgang van

4. Volgens de officieel gehanteerde definitie worden de volgende personen tot de groep voortijdige schoolverlaters gerekend: jongeren tussen de I2 en 23 jaar die zonder startkwalificatie (een diploma op minimaal HAVO- of $\mathrm{MBO}$ 2-niveau) minstens een maand zonder geldige reden hebben verzuimd om onderwijs te volgen en/of niet meer bij een onderwijsinstelling als deelnemer staan ingeschreven. 
onderwijs naar arbeidsmarkt succesvol genoemd kan worden. Beginnende participanten op de arbeidsmarkt zullen vaak in startfuncties terecht komen. Ook voor deze startfuncties geldt dat voor individuen de kwaliteit van het werk toeneemt naarmate de gevonden baan beter aansluit op de gevolgde opleiding voor wat betreft richting en vooral niveau. Figuur 5.I laat zien hoe goed de betaalde werkzaamheden van schoolverlaters aansluiten bij hun afgeronde opleiding voor zover het (I) het opleidingsniveau en (2) de opleidingsrichting betreft.

\section{Aansluiting opleiding-werk naar niveau}

Vanuit maatschappelijk oogpunt is het van belang dat schoolverlaters en afgestudeerden bij voorkeur functies vervullen die passen bij het niveau van hun opleiding. Dat is immers de grondslag van het bestaan van verschillende onderwijssoorten. Ook vanuit individueel oogpunt mag worden verondersteld dat het voor schoolverlaters en afgestudeerden belangrijk is een baan te vinden waar de in de opleiding opgedane competenties optimaal kunnen worden aangewend.

Van alle betaald werkende schoolverlaters heeft driekwart ( $74 \%$; vorige meting $77 \%$ ) een baan op minimaal het eigen opleidingsniveau. Ten opzichte van meting 2008 is het aandeel van de betaald werkende schoolverlaters met een baan die past bij hun opleidingsniveau dus licht gedaald. Van de werkende VMBO uitstroom geeft maar liefst $86 \%$ aan een baan op minimaal eigen niveau te hebben. Dit kan verklaard worden uit het feit dat er weinig banen zijn waar het vereiste opleidingsniveau nog lager is dan VMBO. In die zin is het percentage op niveau werkenden van het VMBO niet echt vergelijkbaar met dezelfde percentages van de andere onderwijsniveaus. Van de gediplomeerde BOL schoolverlaters vindt $78 \%$ een baan op minmaal eigen niveau; bij de BBL is dit 'slechts' $64 \%$. Voor zowel de BOL als de BBL geldt dat de schoolverlaters van de hoogste niveau opleidingen (niveau 4 ) het vaakst werk op eigen niveau hebben. Opvallend is verder het verschil in percentage werkzamen op minimaal eigen niveau tussen de BBL niveau 3 opleidingen en de BBL niveau 4 opleidingen. Het lijkt er op dat hier het I jaar langer volgen van onderwijs duidelijk voordelen heeft als het gaat om het vinden van passend werk.

Het hoger onderwijs laat een gemengd beeld zien. HBO afgestudeerden hebben met gemiddeld $82 \%$ heel vaak een functie op eigen niveau (vooral afgestudeerde docenten), terwijl de WO afgestudeerden duidelijk meer moeite hebben met het vinden van werk op aansluitend niveau (67\%). Met name de WO sector taal en cultuur blijft wat deze indicator betreft duidelijk achter.

\section{Aansluiting opleiding-werk naar richting}

Behalve het niveau is ook de richting van de gevonden functie van belang voor de kwaliteit van het werk. In de vragenlijst is gevraagd om aan te geven wat de door de werkgever vereiste opleidingsrichting is. De vereiste opleidingsrichting zegt iets over de mate waarin de gediplomeerde werkzaamheden verricht die binnen het beroependomein vallen waarvoor hij of zij is opgeleid. Van dit 'eigen' beroependomein is sprake wanneer voor de functie de eigen opleidingsrichting of een daaraan verwante opleidingsrichting vereist is. Werken binnen het 'eigen' beroependomein vergroot de kans dat de in het onderwijs verworven kennis en vaardigheden beter benut zullen worden. Ook vanuit maatschappelijk oogpunt is het van belang dat schoolverlaters terecht komen in beroepen waarvoor zij zijn opgeleid. Dit laatste zal zeker gelden voor de meer beroepsgerichte opleidingen in bijvoorbeeld de sector gezondheidszorg. 
Figuur 5.1

Percentage werkzame schoolverlaters met een baan op minimaal eigen niveau en percentage schoolverlaters met een baan in eigen/verwante richting, per opleidingssector

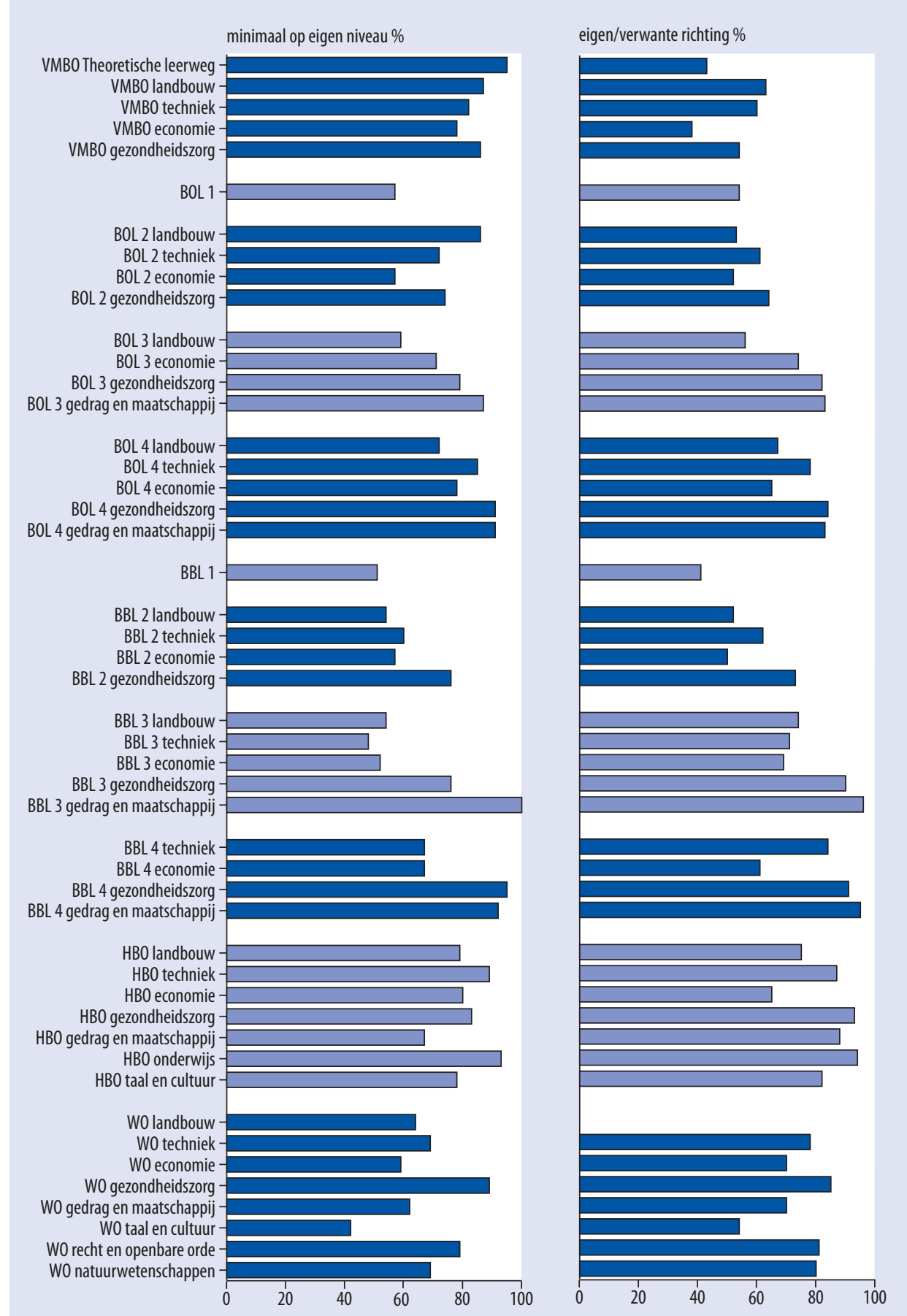

Bron: ROA (SIS);VSNU/IVA, 2009 
Het voorgaande laat onverlet dat de interpretatie van de aansluiting tussen opleiding en werk naar richting minder duidelijk is dan bij de aansluiting naar niveau. Wanneer wordt verondersteld dat de ansluiting uitsluitend verloopt via vakgerelateerde competenties, zou kunnen worden beargumenteerd dat een functie waarvoor uitsluitend de eigen opleidingsrichting wordt vereist beter is dan een functie waarvoor de eigen of een verwante opleidingsrichting wordt vereist, die op zijn beurt weer beter is dan een functie waarvoor een geheel andere of geen specifieke opleidingsrichting wordt vereist. Echter, in steeds meer functies neemt het belang toe van algemene competenties die niet noodzakelijkerwijs op een bepaald vakgebied hoeven te liggen, zoals het kunnen oplossen van complexe problemen, het vermogen zich zelfstandig nieuwe kennis eigen te maken en het kunnen functioneren in een multidisciplinair team. Het valt op die manier te beargumenteren dat een functie waarvoor geen specifieke of een geheel andere opleidingsrichting wordt vereist niet per definitie slechter is dan een functie op vergelijkbaar niveau waarvoor (uitsluitend) de eigen of een daaraan verwante opleidingsrichting wordt vereist.

70\% (meting 2008: 71\%) van alle betaald werkende schoolverlaters werkt in een functie waarvoor de eigen of een verwante opleidingsrichting vereist is. VMBO schoolverlaters zijn het minst vaak en $\mathrm{HBO}$ afgestudeerden het vaakst werkzaam binnen het eigen beroependomein. Bij zowel de BOL als de BBL zijn het de schoolverlaters van de lagere niveaus die het minst vaak werk gevonden hebben dat aansluit wat betreft richting. De meer beroepsgerichte sectoren, gezondheidszorg en gedrag en maatschappij, geven in het MBO de beste garantie voor het vinden van passend werk voor zover het de richting betreft. Dit beroepsgerichte effect van opleidingen zien we ook terug in het hoger onderwijs. In het HBO, waar maar liefst $80 \%$ van alle afgestudeerden binnen de eigen richting werkt, zijn het vooral de meer beroepsgerichte sectoren (onderwijs en gezondheidszorg) die een goede aansluiting hebben met de arbeidsmarkt. In het WO is het eveneens de sector gezondheidszorg waar de beste aansluiting met de arbeidsmarkt wordt gevonden.

Het is een interessante vraag in hoeverre schoolverlaters met werk waarvoor de eigen of een verwante opleidingsrichting is vereist (en die dus binnen hun vakdomein werken) ook vaker op hun opleidingsniveau werkzaam zijn dan schoolverlaters die buiten hun vakdomein werken. Hiervan geeft tabel 5.I een beeld.

Tabel 5.1

$\%$ werkzaam op minimaal eigen opleidingsniveau

$\begin{array}{lcc} & \text { Werkzaam binnen eigen vakdomein } & \text { Werkzaam buiten eigen vakdomein } \\ \text { VMBO } & 93 & 79 \\ \text { BOL } 1+2 & 81 & 45 \\ \text { BOL } 3+4 & 91 & 55 \\ \text { BBL } 1+2 & 75 & 40 \\ \text { BBL } 3+4 & 75 & 39 \\ \text { HBO } & 87 & 60 \\ \text { WO } & 72 & 45 \\ \text { Totaal } & 83 & 55\end{array}$

De cijfers in tabel 5.I laten zien dat verreweg de meeste schoolverlaters die binnen hun vakdomein werken ook op hun opleidingsniveau werkzaam zijn. Schoolverlaters die binnen hun 
vakdomein werken zijn bovendien vaker op hun opleidingsniveau werkzaam dan schoolverlaters die buiten hun vakdomein werken. Van alle betaald werkende schoolverlaters die uitwijken naar een baan buiten hun vakdomein komen BBL'ers het minst vaak en VMBO'ers het vaakst op hun opleidingsniveau terecht. Voor VMBO'ers geldt dat er weinig banen zijn waarvoor het vereiste opleidingsniveau nog lager is dan VMBO.

\section{Benutting/tekortschieten van kennis en vaardigheden}

Naast het niveau en de richting van het gevonden werk is het van belang in hoeverre de verworven kennis en vaardigheden van de gediplomeerden worden benut in hun werk. Het is niet in het belang van de onderwijsinstelling noch in dat van de schoolverlater om kennis en vaardigheden aan te leren die feitelijk niet voor het vervullen van passende functies nodig zijn. Het kan ook zijn dat er te weinig beroep gedaan wordt op deze skills. Van even groot belang is het dat de kennis en vaardigheden niet tekort schieten en er geen kennis en vaardigheden worden gemist. Er is daarom in de schoolverlatersonderzoeken gekeken naar de mate waarin de werkende gediplomeerden in staat zijn om hun opgedane kennis en vaardigheden te benutten en de mate waarin hun kennis en vaardigheden tekort schieten bij de uitoefening van hun werkzaamheden (zie figuur 5.2). Daartoe konden de betaald werkende schoolverlaters op een 5-puntschaal (I 'helemaal niet' <-> 5 'in sterke mate') achtereenvolgens aangeven in welke mate hun capaciteiten in hun huidige functie worden benut en in welke mate hun capaciteiten tekortschieten voor hun huidige functie.

Van de werkende schoolverlaters geeft bijna tweederde (64\%) aan dat de opgedane kennis en vaardigheden in hun werk goed benut worden (antwoordcategorie 4 en 5 ). De verschillen tussen de verschillende onderwijsniveaus variëren van $56 \%$ voor het totale VMBO tot $68 \%$ voor het BBL als geheel. Hoewel de VMBO gediplomeerden over het hele onderwijsveld het laagste scoren op dit onderdeel is toch nog een groot deel van hen van mening dat hun kennis en vaardigheden voldoende benut worden. Dat is opmerkelijk aangezien het formeel om voortijdig schoolverlaters gaat en de opleiding feitelijk niet bedoeld is om direct door te stromen naar de arbeidsmarkt.

De BBL gediplomeerden geven iets vaker aan dat hun kennis en vaardigheden goed benut worden dan hun BOL jaargenoten. Dit is niet verwonderlijk angezien er bij de BBL een sterkere koppeling is tussen werk en opleiding dan bij de BOL: het werk maakt zelfs deel uit van de opleiding. Werknemers beginnen soms vanuit een bestaande arbeidsplaats aan een BBL opleiding en het komt vaak voor dat BBL studenten op het moment van het behalen van hun kwalificatie kunnen blijven werken bij het bedrijf waar ze tijdens de BBL opleiding het praktijkdeel hebben volbracht. In het $\mathrm{MBO}$ zijn het vooral de opleidingen uit de sectoren gezondheidszorg en gedrag en maatschappij waarvan de gediplomeerden aangeven dat hun kennis en vaardigheden voldoende worden benut. Evenals bij de aansluiting opleiding-werk naar niveau en richting springen binnen het $\mathrm{HBO}$ ook hier de leraren er in positieve zin uit.

Een van de tien betaald werkende gediplomeerden vindt dat zijn of haar kennis en vaardigheden voor de huidige werkzaamheden tekortschieten (antwoordcategorie 4 en 5). Er is sprake van een soort tweedeling naar opleidingsniveau: tot en met het $\mathrm{MBO}$ ligt het percentage net boven of net onder de IO\%. In het HBO bedraagt het percentage 6\%. 


\section{Figuur 5.2}

Percentage werkzame schoolverlaters dat aangeeft dat in de huidige functie de opgedane kennis en vaardigheden worden benut en percentage werkende schoolverlaters dat aangeeft dat in de huidige baan de opgedane kennis en vaardigheden tekort schieten, per opleidingssector

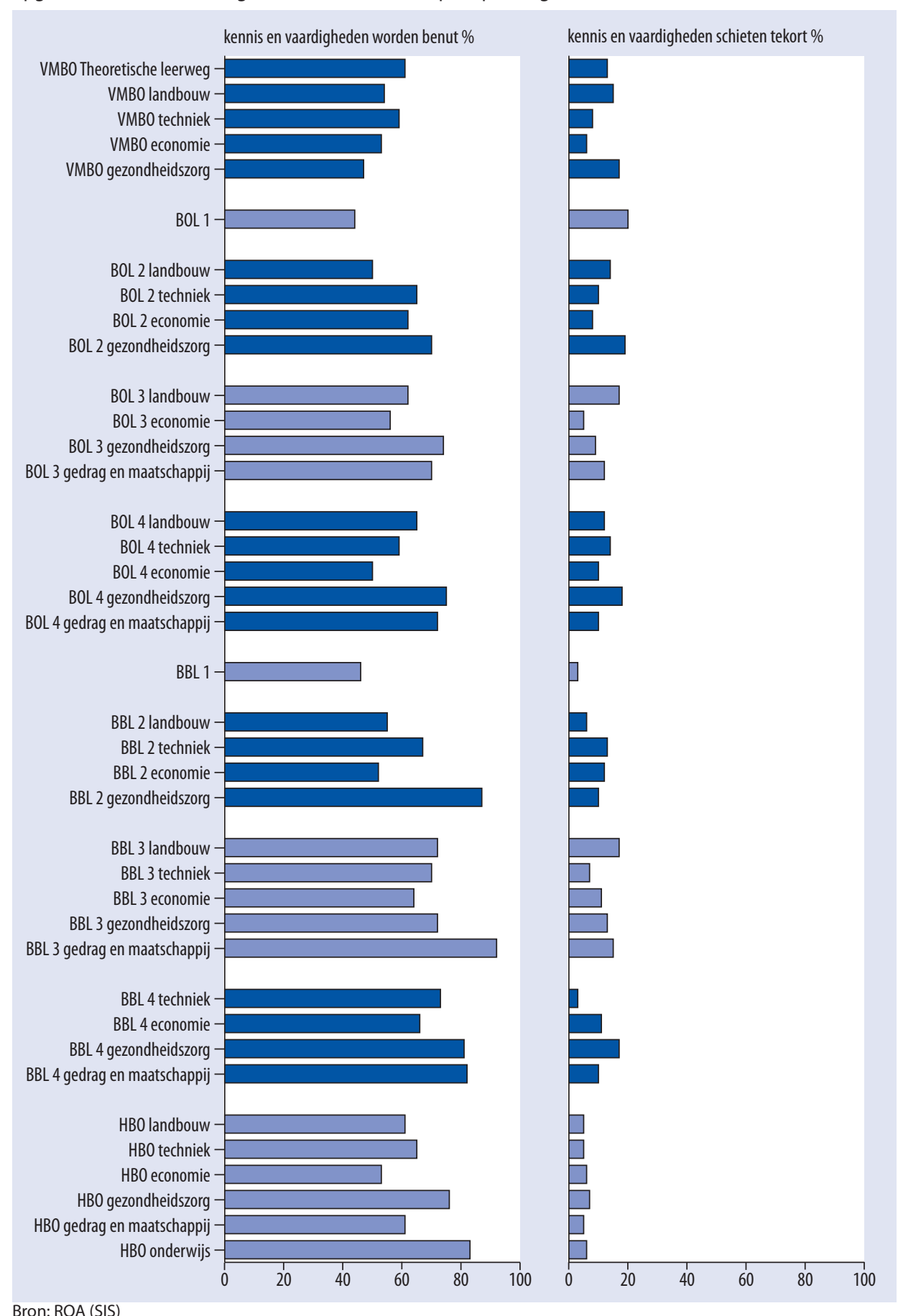




\section{Oordeel over aansluiting opleiding-werk}

De geënquêteerden is eveneens gevraagd aan te geven of ze de aansluiting tussen de gevolgde opleiding en de huidige functie goed, voldoende, matig of slecht vinden. De resultaten van deze vraag staan in figuur 5.3. De hier gepresenteerde cijfers geven aan welk deel van de betaald werkzame gediplomeerde schoolverlaters de aansluiting tussen de gevolgde opleiding en de huidige functie goed of voldoende vindt.

Ruim driekwart (78\%) van de betaald werkende gediplomeerden vindt de aansluiting tussen de gevolgde opleiding en het werk dat ze verrichten goed of voldoende. Gediplomeerden van de BBL vinden het vaakst dat hun werk voldoende of goed aansluit bij hun opleiding. Bij de overige onderwijssoorten liggen de percentages dicht bij elkaar. Binnen het VMBO zijn de schoolverlaters met een techniek of economie diploma op zak het vaakst tevreden over de aansluiting. In het $\mathrm{MBO}$ zijn de BBL gediplomeerden iets vaker tevreden dan de $\mathrm{BOL}$ gediplomeerden. Zoals al eerder vermeld, is een mogelijke verklaring de sterkere relatie tussen opleiding en arbeidsmarkt in de BBL. Binnen het $\mathrm{MBO}$ zijn de oud studenten van de gezondheidszorg opleidingen door de bank genomen het meest te spreken over de aansluiting tussen hun genoten opleiding en hun baan. Dit is in lijn met de eerder besproken resultaten over het hebben van passend werk wat betreft niveau en richting voor deze sector. In het $\mathrm{HBO}$ is driekwart $(76 \%)$ van de werkende afgestudeerden van mening dat de aansluiting tussen opleiding en werk goed of voldoende is. Dat de uitstroom van de HBO lerarenopleidingen de aansluiting zeer goed vindt ligt in de lijn der verwachtingen.

Er is ook nagegaan of het oordeel van betaald werkende schoolverlaters over de aansluiting opleiding-werk samenhangt met het niveau en de richting van hun werk. Dit blijkt slechts deels het geval te zijn:

- Van degenen die op hun opleidingsniveau werken vindt 82\% de aansluiting voldoende of goed, en van degenen die onder hun opleidingsniveau werken 'slechts' $57 \%$.

- Van degenen die binnen hun vakdomein werken vindt $84 \%$ de aansluiting voldoende of goed, en van degenen die buiten hun vakdomein werken 'slechts' $53 \%$.

Het lijkt er dus op dat het subjectieve oordeel over de aansluiting opleiding-werk met meer dingen samenhangt dan het formeel vereiste opleidingsniveau en de formeel vereiste opleidingsrichting.

\section{Tevredenheid met functie}

In figuur 5.4 komt een wat meer subjectieve, maar voor de schoolverlaters zelf niet onbelangrijke indicator aan de orde. Er is hen de vraag voorgelegd 'Hoe tevreden bent u met uw huidige functie?'. De meeste betaald werkende schoolverlaters (72\%) zijn tevreden met hun huidige functie. In het $\mathrm{VMBO}$ is men met $8 \mathrm{I} \%$ het meest vaak tevreden (vooral de gediplomeerden $\mathrm{VMBO}$ techniek zijn vaak tevreden over hun functie). Er zijn binnen het $\mathrm{MBO}$ weinig systematische verschillen tussen de sectoren per onderwijsniveau. In het $\mathrm{HBO}$ zijn de afgestudeerden van de sector economie relatief vaak ontevreden. In het WO geldt dit voor de sector taal en cultuur. 


\section{Figuur 5.3}

Percentage werkzame schoolverlaters dat de aansluiting tussen opleiding en werk als goed of voldoende beoordeelt, per opleidingssector

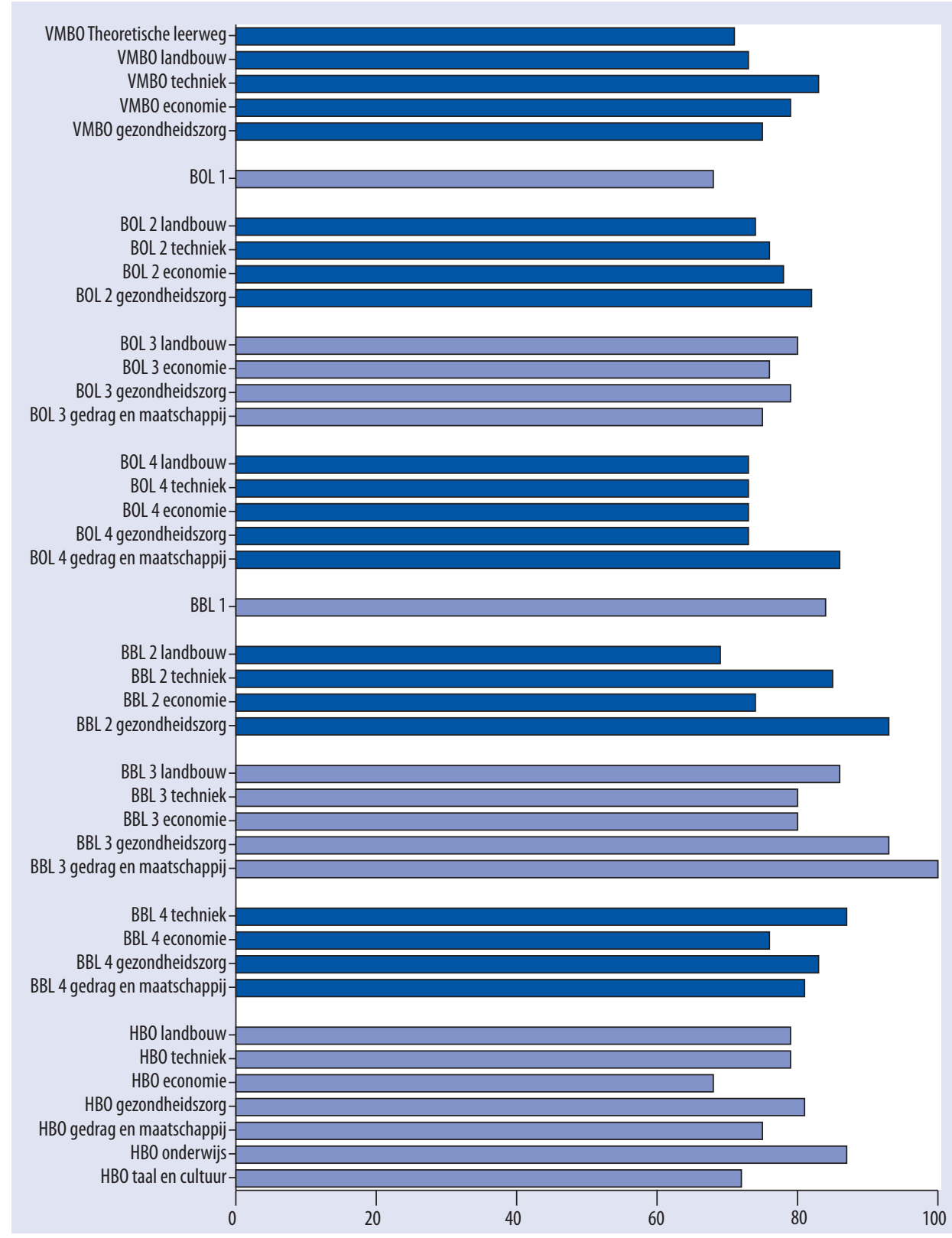

Bron: ROA (SIS) 


\section{Figuur 5.4}

Percentage werkzame schoolverlaters dat tevreden is met huidige functie

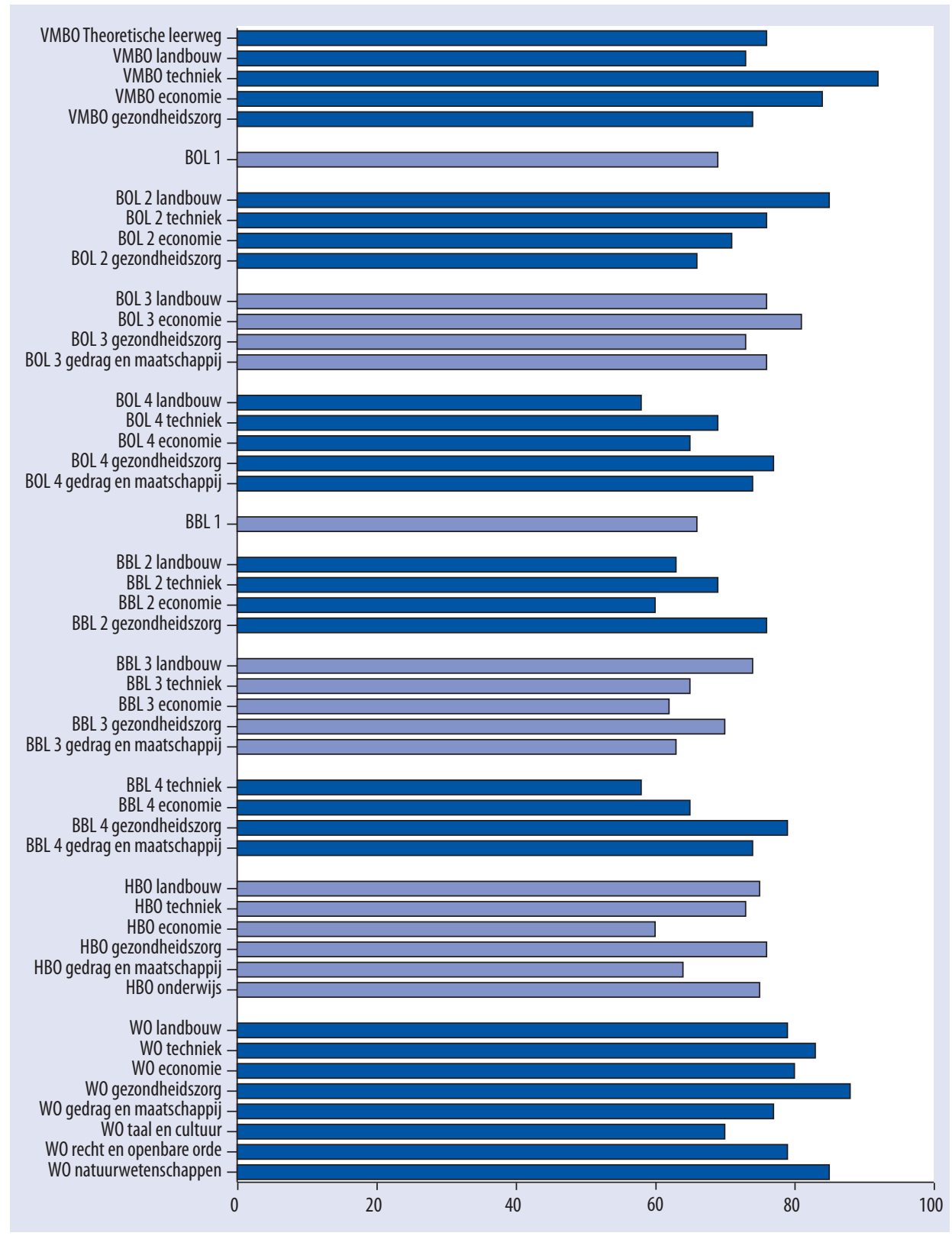

Bron: ROA (SIS); VSNU/IVA, 2009 


\subsection{Extern rendement}

Om inzicht te krijgen in het extern rendement, de doelmatigheid van het onderwijs, met betrekking tot de arbeidsmarkt wordt in de rest van dit hoofdstuk een aantal arbeidsmarktindicatoren voor de verschillende onderwijsniveaus naast elkaar gezet.

\section{Arbeidsmarktparticipatie en kans op werk}

In figuur 5.5 staat welk deel van de schoolverlaters zich aanbiedt op de arbeidsmarkt en welk deel van deze aanbieders op het moment van enquêteren werkloos is. Hierbij zij opgemerkt dat jongeren die in economisch minder goede tijden hun opleiding afronden meer moeite zullen hebben om werk te vinden en minder vaak werk zullen vinden dat bij hun opleidingsniveau past. Bovendien moeten zij zich, in vergelijking met jongeren die zich in economisch goede jaren op de arbeidsmarkt aanbieden, vaker tevreden stellen met relatief minder goede arbeidsvoorwaarden. De baten die men zou hebben als men zich zou aanbieden op de arbeidsmarkt zijn daarom in slechte tijden aanzienlijk lager en maken eventueel beschikbare alternatieven als doorstroom naar vervolgonderwijs aantrekkelijker. In hoofdstuk 4 hebben we stil gestaan bij de doorstroom naar vervolgonderwijs

Figuur 5.5 laat zien dat ruim de helft (54\%; meting 2008: 55\%) van de gediplomeerde schoolverlaters zich na het verlaten van de opleiding richt op de arbeidsmarkt. Vanwege de verschillende functies van de onderscheiden onderwijssoorten zijn de verschillen in het percentage aanbieders zeer groot. Ruim een kwart (28\%) van de VMBO uitstroom richt zich op de arbeidsmarkt. Hierbij dient opgemerkt te worden dat ongeveer $\mathrm{I} 4 \%$ dit doet in de vorm van een BBL opleiding. Gezien het feit dat een VMBO diploma geen startkwalificatie is, ligt dit aandeel van $\mathrm{I} 4 \%$ dat werkelijk de arbeidsmarkt betreedt nog redelijk hoog. Evenals verleden jaar zijn het vooral de VMBO technici die zich aanbieden voor betaalde werkzaamheden. Van de BOL uitstroom biedt $59 \%$ zich aan op de arbeidsmarkt, en van de BBL uitstroom vrijwel iedereen (95\%). Ook vrijwel alle afgestudeerde WO'ers richten zich op de arbeidsmarkt (94\%). Onder de HBO gediplomeerden ligt dit aandeel iets lager namelijk 83\%.

De doelmatigheid van het onderwijs wordt in eerste instantie bepaald door de vraag of de schoolverlaters die naar de arbeidsmarkt gaan werk hebben gevonden. De totale werkloosheid onder de schoolverlaters bedraagt 6\%. Dit is $1 \%$-punt meer dan in meting 2008.

Ondanks de economische crisis is de werkloosheid onder gediplomeerde schoolverlaters van het laagste opleidingsniveau, het VMBO, ten opzichte van de vorige meting (eind 2008) niet gestegen maar zelfs gedaald, en wel van $9 \%$ naar $6 \%$. Deze daling heeft zich voorgedaan bij alle opleidingssectoren van het $\mathrm{VMBO}$. Een mogelijke oorzaak voor deze opvallende uitkomst is te vinden in het afnemende aandeel VMBO-ers dat zich op de arbeidsmarkt aanbiedt in combinatie met een nog steeds relatief stabiele arbeidsmarkt voor deze groep schoolverlaters. De gevolgen van de economische crisis in de vorm van gestegen werkloosheidscijfers doen zich wel voor onder gediplomeerden van de overige onderwijssoorten. Zo steeg de werkloosheid ten opzichte van de vorige meting (eind 2008) onder gediplomeerden van de BOL van $5 \%$ naar $10 \%$, onder gediplomeerden van de BBL van $\mathrm{I} \%$ naar $3 \%$, onder afgestudeerden van het $\mathrm{HBO}$ van $4 \%$ naar $6 \%$ en onder afgestudeerden van het WO van $4 \%$ naar $5 \%$. 


\section{Figuur 5.5}

Percentage gediplomeerde schoolverlaters dat zich aanbiedt op de arbeidsmarkt en werkloosheidspercentage onder gediplomeerde schoolverlaters, per opleidingssector

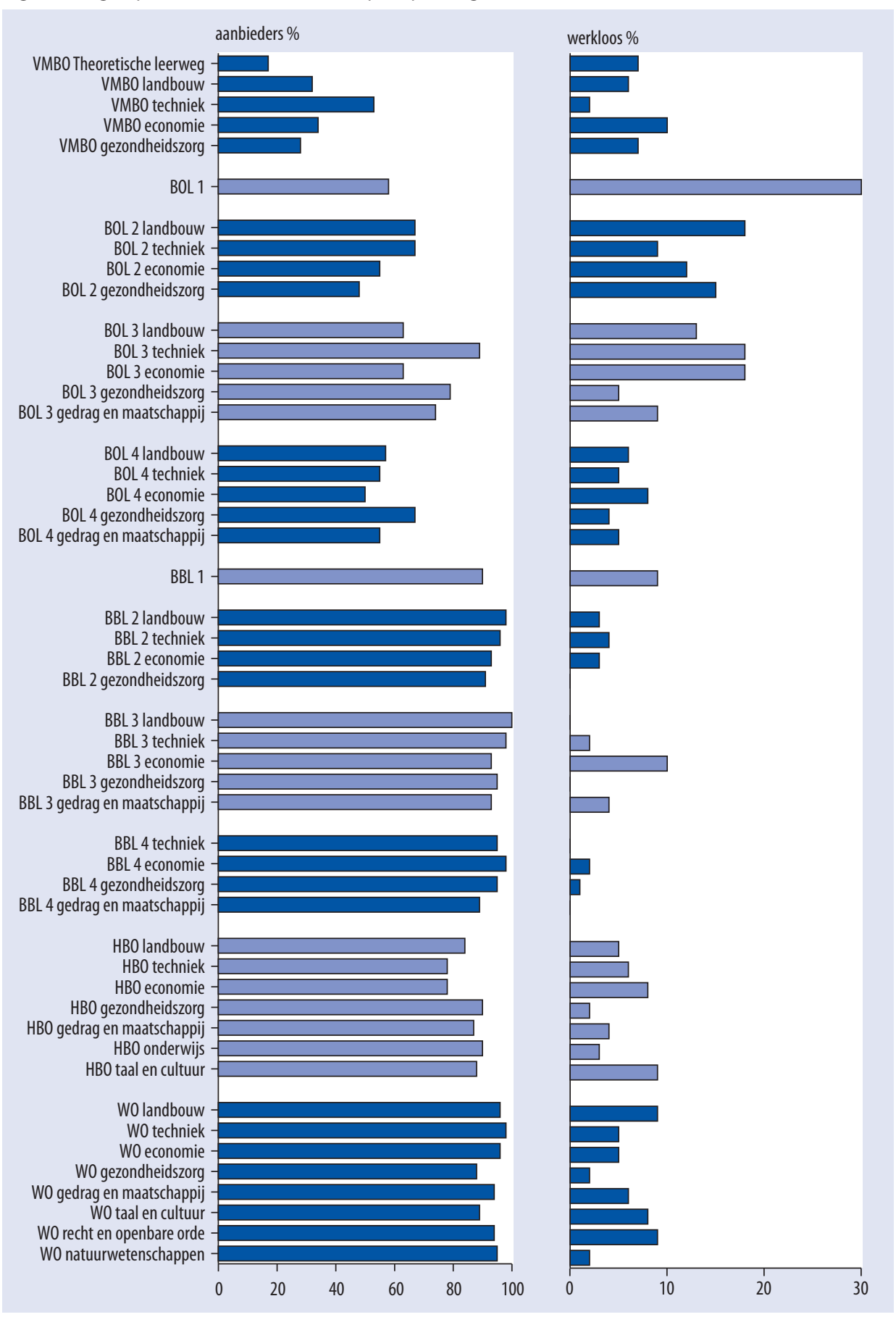

Bron: ROA (SIS); VSNU/IVA, 2009 
De stijging van de werkloosheid onder de BOL gediplomeerden manifesteert zich bij alle opleidingsniveaus van de BOL. De werkloosheid is duidelijk het hoogst onder BOL niveau I gediplomeerden, hetgeen de gedachtegang ondersteunt dat een BOL niveau I opleiding geen geschikte startkwalificatie is. In de BOL geldt overigens dat het werkloosheidspercentage afneemt naarmate het opleidingsniveau stijgt.

Hoewel ook onder de BBL uitstroom de werkloosheid ten opzichte van de vorige meting (eind 2008) is toegenomen, is deze met $3 \%$ nog steeds erg laag (zeker wanneer rekening gehouden wordt met het feit dat er altijd personen tijdelijk werkloos kunnen zijn omdat ze van baan aan het wisselen zijn: frictiewerkloosheid). Overigens is ten opzichte van verleden jaar de werkloosheid bij gediplomeerden van de BBL het sterkst gestegen onder niveau I gediplomeerden (van I\% naar 9\%), gevolgd door niveau 2 en niveau 3 gediplomeerden (van $\mathrm{I} \%$ naar $3 \%)$. Onder niveau 4 gediplomeerden is de werkloosheid niet veranderd ten opzichte van eind 2008 (onverminderd $\mathrm{I} \%$ ).

Ten opzichte van verleden jaar is de werkloosheid onder afgestudeerden van het $\mathrm{HBO}$ vooral gestegen onder afgestudeerden van technische en economische opleidingen. Onder afgestudeerden van het WO steeg de werkloosheid ten opzichte van meting 2008 bij alle opleidingssectoren, behoudens bij WO gezondheidszorg.

Zoals al eerder is vermeld, worden in dit hoofdstuk de schoolverlaters besproken die in schooljaar 2007-2008 de opleiding hebben verlaten. Zij hebben de arbeidsmarkt betreden in de zomer en herfst van 2008. De bovenstaande cijfers tonen dat dit meetjaar (najaar 2009) de economische crisis in sommige werkloosheidscijfers duidelijk tot uiting is gekomen (zie ook de trendcijfers in bijlage 3). Dit jaar is er, behoudens bij VMBO'ers, sprake van een (verder) stijgende werkloosheid onder gediplomeerden van de BOL (alle niveaus), niveau I gediplomeerden van de BBL en afgestudeerden van het $\mathrm{HBO}$ en WO.

Uit figuur 5.5 blijkt dat het merendeel van de startende schoolverlaters een baan heeft op het moment van enquêteren. Dit hoeft niet de eerste baan te zijn en men hoeft deze baan ook niet meteen gevonden te hebben. Het percentage werkenden zegt met andere woorden niet alles over hoe soepel de intrede op de arbeidsmarkt verlopen is. In figuur 5.6 staan daarom enige cijfers over de zoekduur naar de eerste baan. In de figuur staat het percentage van de schoolverlaters dat 4 maanden of langer werkloos geweest is voordat ze hun eerste baan vonden.

Van alle gediplomeerde schoolverlaters die de arbeidsmarkt instromen heeft $5 \%$ vier maanden of langer moeten zoeken naar een baan. Hierbij moet worden aangetekend dat de transitie naar de arbeidsmarkt net voor het uitbreken van de economische crisis heeft plaatsgevonden. Ter vergelijking: de meting van het werkloosheidspercentage heeft plaatsgevonden in het najaar van 2009, dus na het uitbreken van de economische crisis. De gediplomeerden van de BBL hebben duidelijk minder moeite met het vinden van hun eerste baan dan de gediplomeerden van de andere onderwijssoorten (met name afgestudeerden uit het HBO). Het laatste ligt ook voor de hand omdat hoger opgeleiden er meer baat bij hebben om wat langer te zoeken naar een voor hen geschikte baan.

Van de MBO'ers hebben de gediplomeerden van de niveau I opleidingen in de BOL (vooral techniek en economie) het langst moeten zoeken voordat de eerste baan gevonden werd. 
Figuur 5.6

Percentage gediplomeerde schoolverlaters dat voorafgaand aan de eerste baan minimaal 4 maanden werkloos was

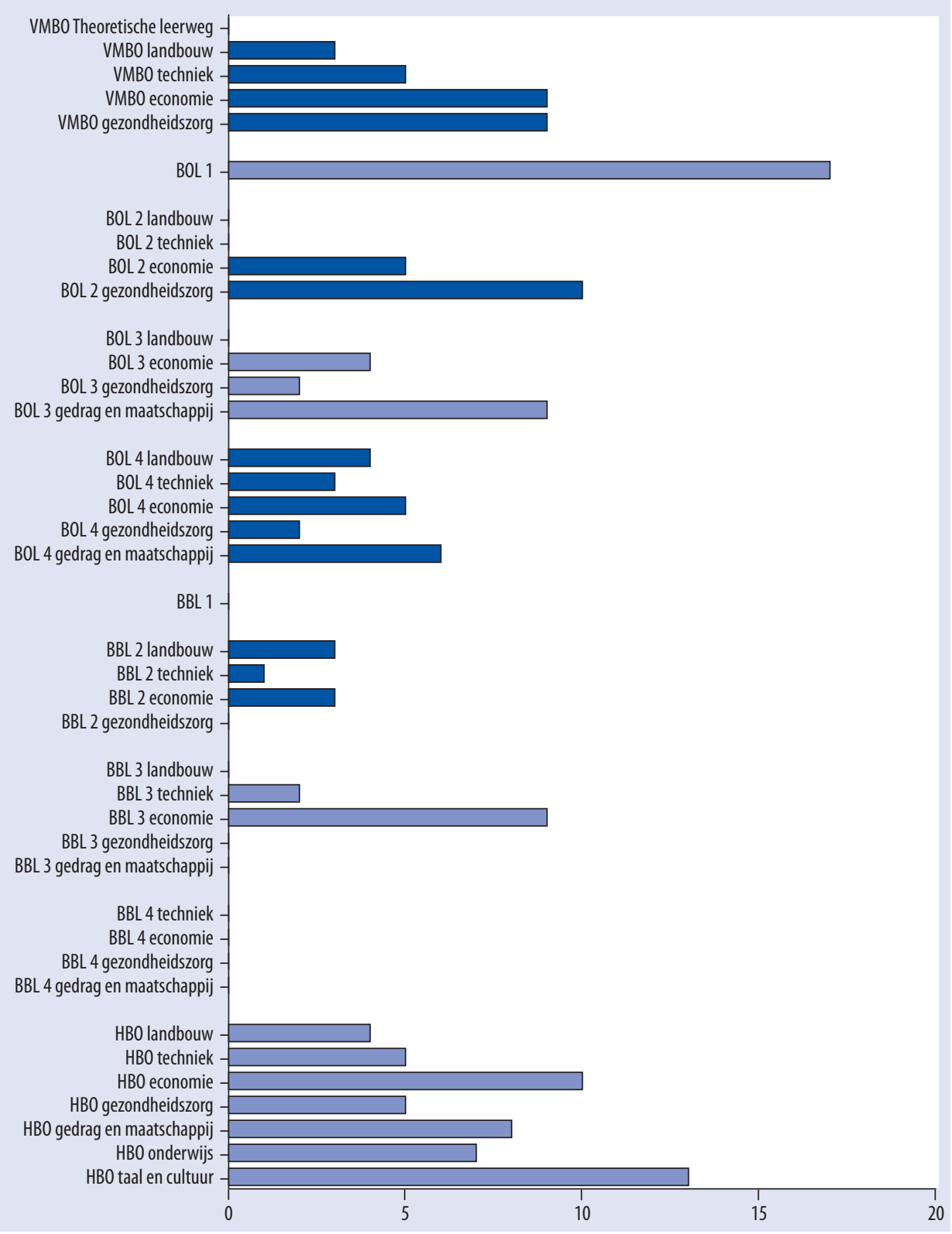

Bron: ROA (SIS) 
Ook de BOL niveau 2 gezondheidszorg gediplomeerden hebben, evenals verleden meetjaar, relatief vaak lang moeten zoeken naar hun eerste baan. Binnen het HBO hebben de HBO landbouw, $\mathrm{HBO}$ techniek en $\mathrm{HBO}$ gezondheidszorg afgestudeerden de minste moeite met het snel vinden van werk.

\section{Werkzekerheid}

Behalve het al dan niet hebben van een betaalde baan is de werkzekerheid een belangrijke indicator van het extern rendement van het onderwijs. De twee kenmerken die in figuur 5.7 gepresenteerd worden geven een indicatie van deze werkzekerheid. In de figuur staat het percentage van de werkende schoolverlaters met een flexibele aanstelling en het percentage met een deeltijdaanstelling. Onder een flexibele aanstelling wordt verstaan een aanstelling als uitzendkracht, oproepkracht e.d. of een tijdelijke aanstelling. Van een deeltijdaanstelling is sprake wanneer iemand een aanstelling van 32 uur of minder per week heeft. Van de betaald werkende gediplomeerde schoolverlaters heeft overigens $40 \%$ een tijdelijke aanstelling terwijl $5 \%$ als uitzend-/oproepkracht werkt.

Er zijn nogal wat verschillen tussen de onderwijsniveaus ten aanzien van het aandeel van betaald werkende schoolverlaters met een flexibele aanstelling. Zo heeft van de werkende VMBO uitstroom maar liefst $63 \%$ een flexibel contract terwijl van de uitstroom uit het BBL een kwart van de werkenden een flexibele aanstelling heeft. Voor de BOL en het HBO geldt dit voor bijna de helft van de werkenden.

Onder de BOL niveau I en 2 gediplomeerden wordt iets vaker met een flexibele aanstelling gewerkt dan onder de BOL niveau 3 en 4 gediplomeerden. Onder de BBL niveau 4 gediplomeerden wordt minder vaak met een flexibele aanstelling gewerkt dan onder de gediplomeerden van de andere niveaus binnen de BBL. In het MBO is er verder geen sector die er structureel uitspringt met betrekking tot het percentage werkenden met een flexibel arbeidscontract. In het $\mathrm{HBO}$ werken taal en cultuur afgestudeerden het vaakst via een flexibele aanstelling.

In figuur 5.7 staan eveneens de percentages werkenden met een deeltijdaanstelling. In het VMBO heeft bijna 2 van de 3 werkenden een deeltijdaanstelling tegenover I op de 5 in het WO. Binnen het VMBO zijn het de uitstromers uit de sector gezondheidszorg die het vaakst minder dan 32 uur werken. Onder de betaald werkende gediplomeerden van de BOL heeft iets meer dan de helft een deeltijdaanstelling. Naarmate binnen de BOL het onderwijsniveau stijgt, daalt het aandeel werkenden met een deeltijdaanstelling. Over de gehele BOL bezien werken de agrariërs en technici het minst vaak in deeltijd, terwijl de gedrag en maatschappij en gezondheidszorg gediplomeerden relatief vaak een deeltijdbaan hebben. Dezelfde verhouding tussen de sectoren is terug te vinden in de BBL. Zowel in het $\mathrm{HBO}$ als in het $\mathrm{WO}$ zijn er grote verschillen tussen de sectoren. De HBO technici en economen werken zelden in deeltijd, en de gezondheidszorg en gedrag en maatschappij afgestudeerden relatief vaak. In het WO zijn het de technici, economen en juristen die vrijwel altijd een volledige baan hebben. Minder dan IO\% van hen werkt in deeltijd. 


\section{Figuur 5.7}

Percentage werkzame schoolverlaters met een flexibele aanstelling en percentage werkzame schoolverlaters met een deeltijdaanstelling, per opleidingssector

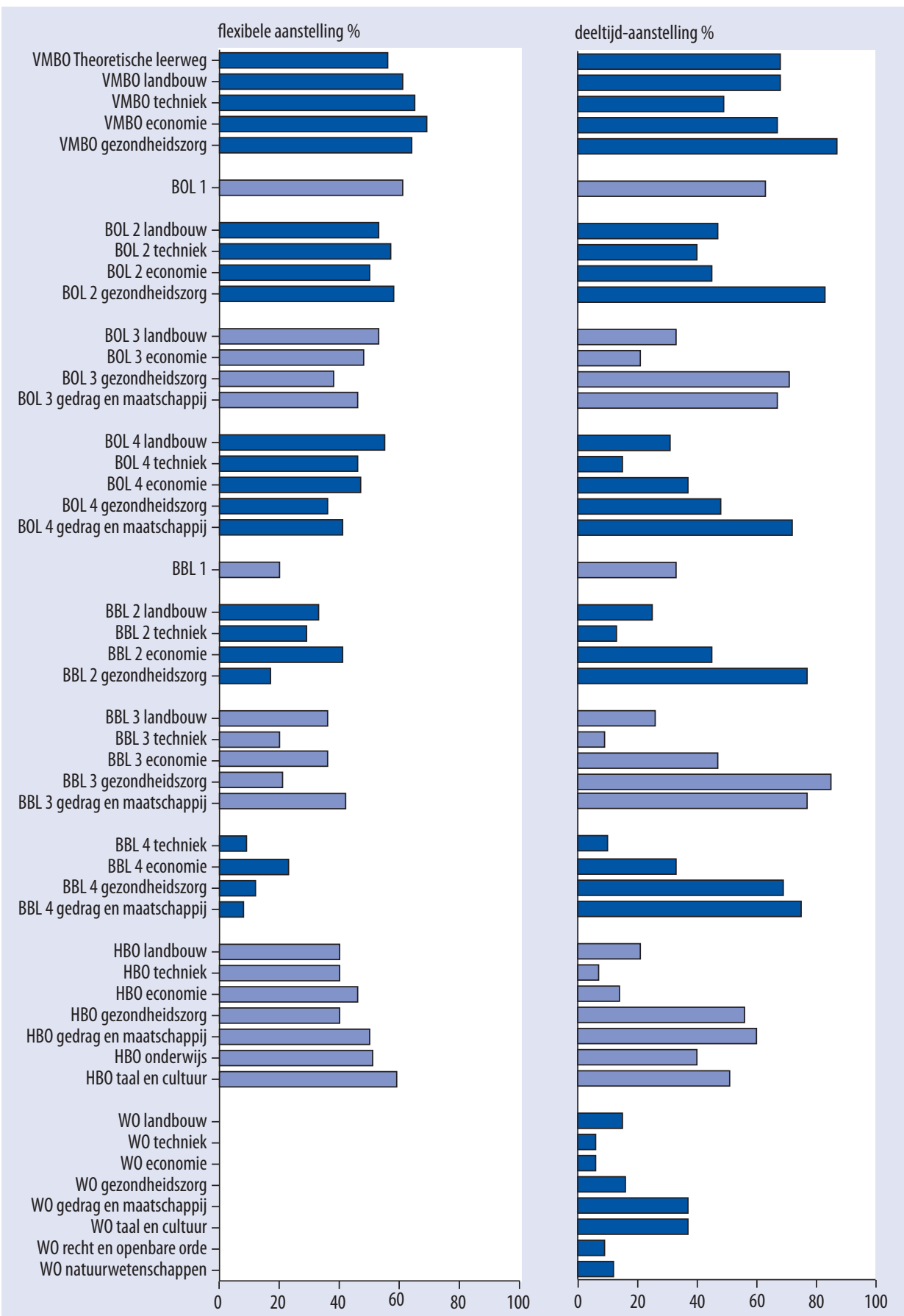

WO: voor indicator flexiblele aanstelling geen vergelijkbare cijfers bekend Bron: ROA (SIS); VSNU/IVA, 2009 
Een derde indicator voor het rendement op de arbeidsmarkt is de beloning. In figuur 5.8 staan per opleidingssector de gemiddelde bruto uurlonen vermeld. Het gemiddeld bruto uurloon van werkende schoolverlaters neemt toe met hun opleidingsniveau. BBL schoolverlaters verdienen gemiddeld genomen meer dan hun studiegenoten van de BOL. Dit wordt veroorzaakt door het duale karakter van het onderwijs en het leeftijdsverschil. De gemiddelde werkende BBL schoolverlater is zo'n 7,5 jaar ouder dan de (werkende) BOL schoolverlater en is vaak ook al wat langer werkzaam. Binnen de BOL zijn het met name schoolverlaters uit de sector landbouw die vrij weinig verdienen ten opzichte van de andere BOL gediplomeerden van hetzelfde niveau. Binnen de BBL niveaus geldt dit meer voor de schoolverlaters met een opleiding uit de sector economie. Binnen het $\mathrm{HBO}$ hebben de afgestudeerden uit de sector gezondheidszorg het beste uurloon.

\section{Carrièreperspectieven}

Een ander belangrijk, zij het subjectief, onderdeel van het extern rendement zijn de geboden toekomstperspectieven. Wat zijn de doorgroeimogelijkheden met betrekking tot werkzaamheden, salaris, promotie en persoonlijke ontplooiing? In de enquête is aan de respondenten gevraagd om op een 5-puntschaal (van 'nauwelijks' tot 'heel veel') aan te geven in hoeverre hun functie goede carrièremogelijkheden biedt. Figuur 5.9 geeft het percentage werkende schoolverlaters weer dat van mening is dat hun huidige functie goede tot heel goede carrièreperspectieven biedt (antwoordcategorie 4 en 5 ).

Het aandeel van de betaald werkende schoolverlaters die van mening zijn dat hun functie goede tot zeer goede carrièremogelijkheden biedt, is het hoogst onder de laagst opgeleiden (VMBO'ers). Binnen het VMBO zien vooral de techniek schoolverlaters goede mogelijkheden voor hun verdere loopbaan. Gemiddeld zien de BBL schoolverlaters iets minder carrièreperspectieven dan hun BOL studiegenoten, maar het verschil is maar klein. Binnen de BBL zijn de meningen positiever naarmate het opleidingsniveau hoger wordt. Dit patroon doet zich niet voor binnen de BOL, waar de gediplomeerden van niveau 2 opleidingen het vaakst positief zijn over hun carrièremogelijkheden. Van de $\mathrm{HBO}$ afgestudeerden ziet de helft $(5 \mathrm{I} \%)$ goede loopbaanmogelijkheden, waarbij technici het meeste vertrouwen en afgestudeerde leraren het minste vertrouwen in hun carrièremogelijkheden hebben.

\section{Tevredenheid achteraf}

Voor de schoolverlaters van het $\mathrm{MBO}$ en de afgestudeerden uit het hoger onderwijs die naar de arbeidsmarkt zijn gegaan wordt tot slot nog gekeken in hoeverre ze de door hen afgesloten opleiding achteraf bezien opnieuw zouden kiezen. De overgrote meerderheid van de gediplomeerden die naar de arbeidsmarkt zijn gegaan zouden dezelfde opleiding weer volgen. Door de bank genomen zijn schoolverlaters met een economische achtergrond vaak relatief weinig tevreden over hun destijds gemaakte opleidingskeuze, hoewel ook zij in meerderheid tevreden zijn. 
Figuur 5.8

Gemiddeld bruto uurloon van werkzame schoolverlaters, per opleidingssector

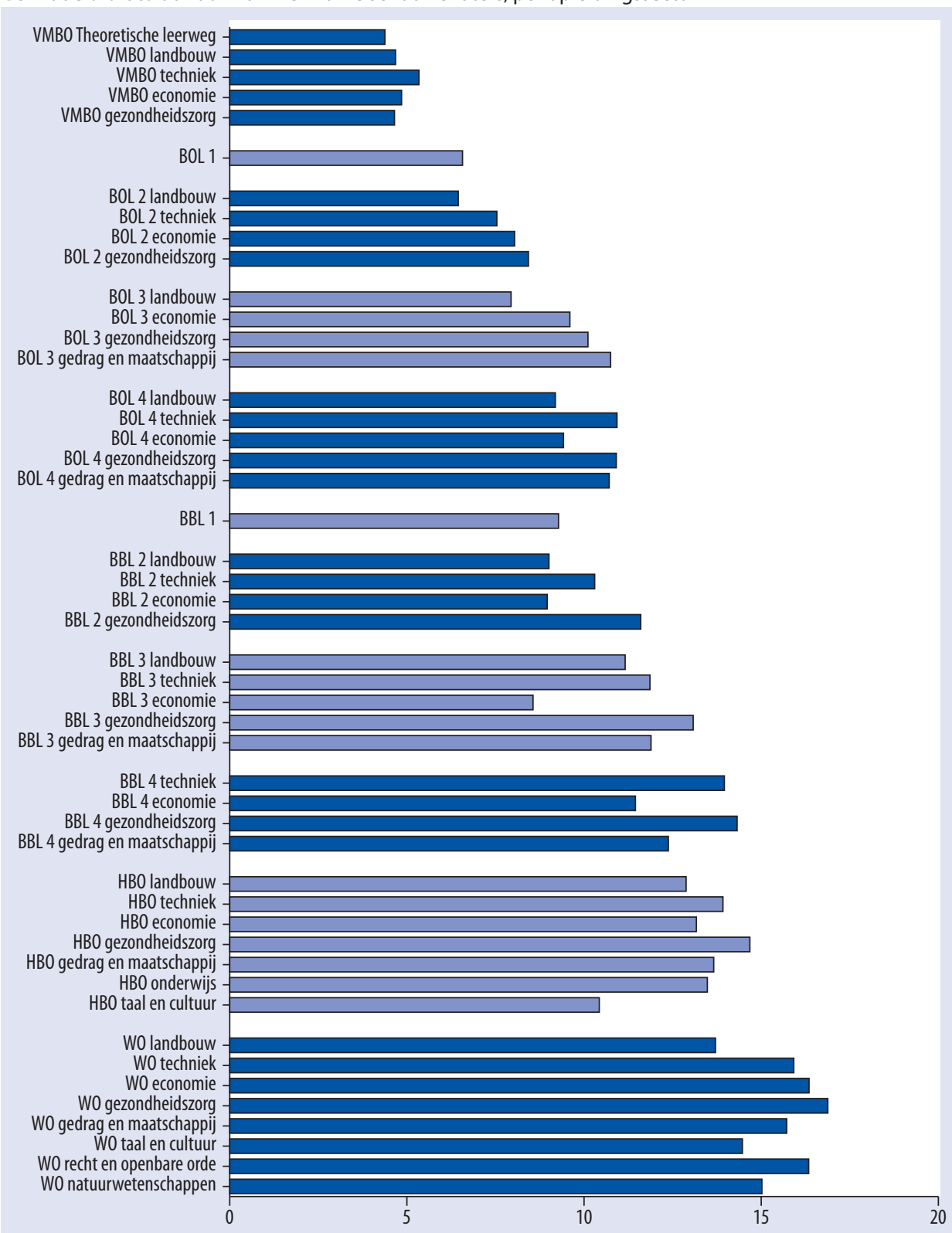

Bron: ROA (SIS); VSNU/IVA, 2009 


\section{Figuur 5.9}

Carrièreperspectieven in huidige functie

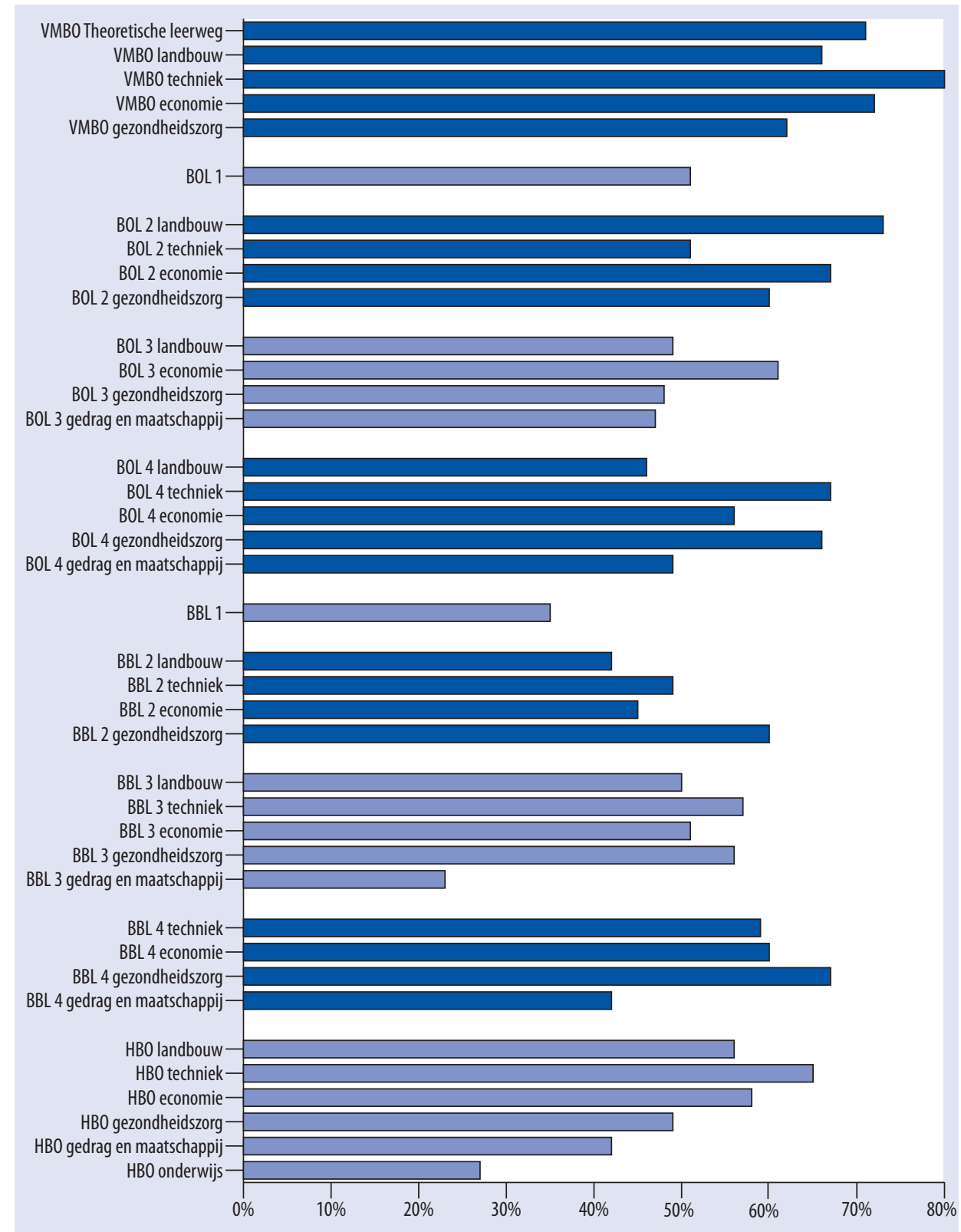

Bron: ROA (SIS) 


\section{Figuur 5.10}

Percentage werkzame schoolverlaters dat achteraf bezien dezelfde opleiding zou volgen, per opleidingssector

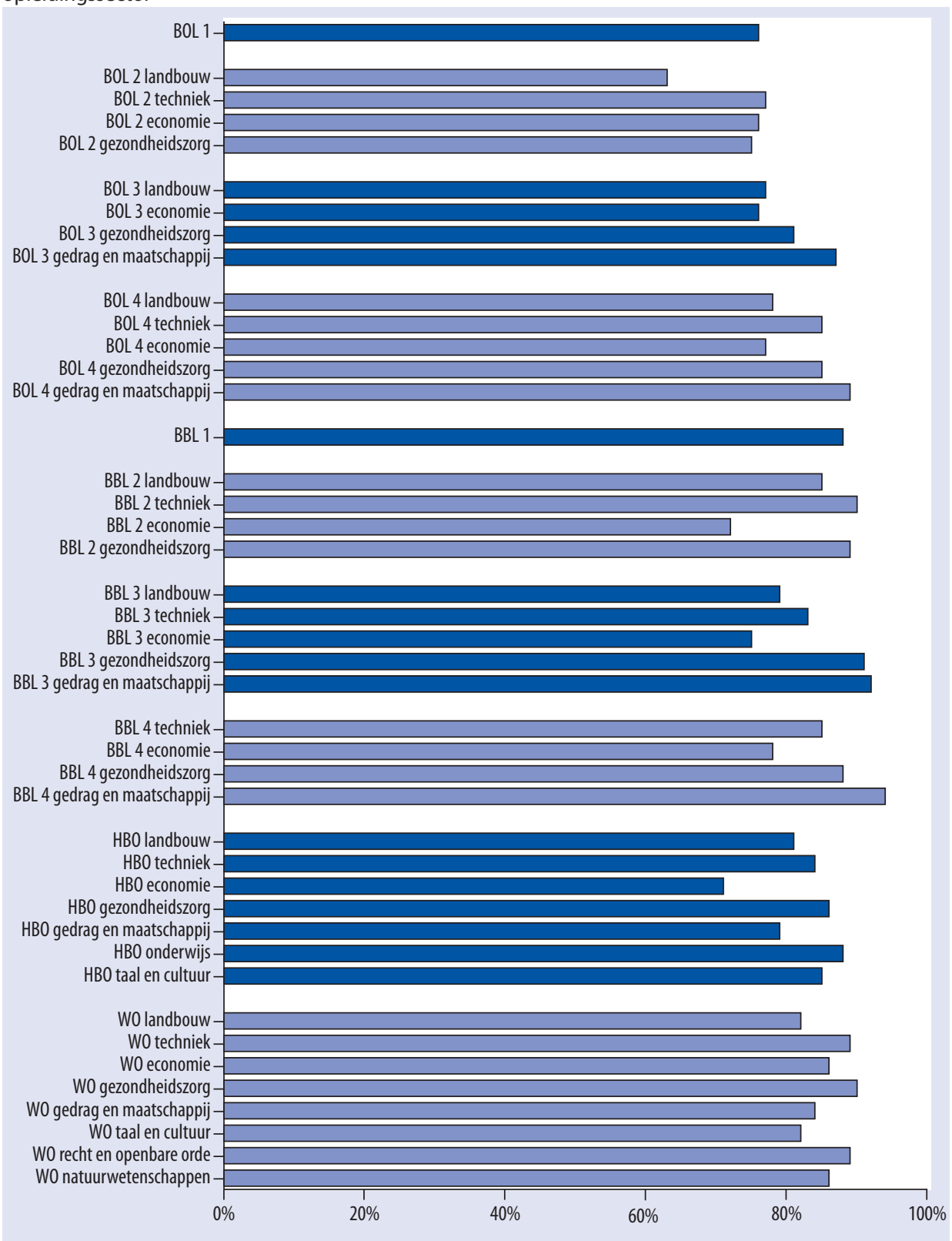

Bron: ROA (SIS); VNSU/IVA, 2009 


\section{Effect van de conjuncturele malaise}

Ter afsluiting van dit rapport staan we stil bij het effect van de huidige conjuncturele malaise op de arbeidsmarktintrede van gediplomeerde schoolverlaters van het $\mathrm{MBO}$ en afgestudeerden van het HBO.5 De vraag is of de minder succesvolle transitie naar de arbeidsmarkt, gemeten eind 2009, een direct gevolg is van de economische crisis. Om deze vraag te beantwoorden is op basis van het SchoolverlatersInformatieSysteem van het ROA een additionele analyse uitgevoerd naar de kans op werk van gediplomeerde schoolverlaters van voltijdse opleidingen in goede en slechte economische tijden. De kans op werk heeft daarbij betrekking op de situatie circa I, 5 jaar na het behalen van het diploma. In de analyse zijn de economisch goede tijden geoperationaliseerd als de meetjaren $1996 \mathrm{t} / \mathrm{m} 2000$ en $2006 \mathrm{t} / \mathrm{m} \mathrm{2008}$, en de economisch slechte tijden als de meetjaren $200 \mathrm{t} / \mathrm{m} 2005$ en meetjaar 2009. De resultaten van de analyse staan in tabel 6.I samengevat. Om de analyse van het effect van de gevolgde onderwijssoort zo zuiver mogelijk te houden, is onder meer gecontroleerd voor eventuele verschillen ten aanzien van etniciteit, leeftijd, geslacht, behaald examencijfer en regio waarin men de opleiding heeft gevolgd. ${ }^{6}$

Vergeleken met gediplomeerde schoolverlaters van de hogere niveaus van de BOL, zien we dat in economisch slechte tijden de kans op werk voor gediplomeerde schoolverlaters van de BBL en de lagere niveaus van de BOL licht daalt en voor HBO afgestudeerden licht toeneemt. Met andere woorden, in economisch slechte tijden gaan de hogere opleidingsniveaus er minder op achteruit dan de lagere opleidingsniveaus. Kijken we naar de rol van de regio waar men de opleiding heeft gevolgd, dan zien we het volgende beeld. In economisch slechte tijden daalt de kans op werk in regio noord en regio zuid en neemt de kans op werk in regio west toe, althans ten opzichte van regio oost. Met andere woorden, in economisch slechte tijden komt de relatief gunstige werkgelegenheidssituatie van regio west naar voren.

Uit de in dit rapport beschreven resultaten blijkt dat de verslechterde conjuncturele situatie van 2009 een negatieve invloed lijkt te hebben gehad op de kans van schoolverlaters om werk te vinden, de werkzekerheid en het niveau van het gevonden werk. De vraag is of de ongunstige conjuncturele situatie bij het betreden van de arbeidsmarkt ook gevolgen zal hebben voor hun latere loopbaan. Met andere woorden, ondervinden deze jongeren slechts op korte termijn problemen bij het vinden van werk of zijn de gevolgen van de instroom op de arbeidsmarkt in een slechte conjunctuur van blijvende aard? In eerder uitgevoerde analyses

5. Voor de afgestudeerden van het WO zijn deze gegevens slechts gedeeltelijk beschikbaar. Zij zijn daarom niet meegenomen in de analyses. Verder worden het VO en het VMBO buiten de beschouwing gelaten omdat deze onderwijssoorten bedoeld zijn om door te stromen naar vervolgonderwijs (al dan niet in combinatie met werken).

6. De regio noord omvat de provincies Groningen, Friesland en Drenthe. De regio oost omvat de provincies Overijssel en Gelderland, de regio west omvat de provincies Utrecht, Noord-Holland, Zuid-Holland en Zeeland, en de regio zuid omvat de provincies Noord-Brabant en Limburg. 
(Allen, J., et al, 2009; ROA, 2009) is op deze vraag uitgebreid ingegaan. Hieruit is naar voren gekomen dat een economische crisis geen blijvende negatieve invloed heeft op de latere loopbaan van schoolverlaters. Op lange termijn is dus niet te verwachten dat schoolverlaters die tijdens de 2009 recessie de arbeidsmarkt hebben betreden een verhoogde kans op werkloosheid hebben, op een lager niveau werken of een lager salaris ontvangen. Gelukkig is er dus geen sprake van een verloren generatie.

Tabel 6.1

Kans op werk in Goede Tijden/Slechte Tijden

$\begin{array}{lc} & \text { Regressie coëfficiënten } \\ \text { Goede tijden } & \\ \text { Onderwijssoort: } & \\ \text { - BOL 3/4 (referentie) } & \\ \text { - BOL 1/2 } & -0,899 \\ \text { - BBL 1/2 } & 0,976 \\ \text { - BBL 3/4 } & 1,846 \\ \text { - HBO } & X \\ \text { Regio: } & \\ \text { - Oost (referentie) } & \\ \text { - Noord } & -0,306 \\ \text { - West } & X \\ \text { - Zuid } & 0,355 \\ & \\ \text { Slechte tijden } & \\ \text { Onderwijsoort: } & \\ \text { - BOL 3/4 (referentie) } & \\ \text { - BOL 1/2 } & \\ \text { - BBL 1/2 } & \\ \text { - BBL 3/4 } & \\ \text { - HBO } & -0,757 \\ \text { Regio: } & 0,730 \\ \text { - Oost (referentie) } & 1,331 \\ \text { - Noord } & 0,300 \\ \text { - West } & \\ \text { - Zuid } & \\ \text { Bron: ROA (SIS) } & \\ & -0,447 \\ & \\ & \\ & \\ & \end{array}$

Overigens kunnen opleidingen hun studenten meer 'recessie-proof' maken door meer aandacht te schenken aan voorlichting over studie- en beroepsmogelijkheden en meer aandacht te besteden aan stages en/of andere mogelijkheden voor hun studenten om relevante werkervaring op te doen. Studenten kunnen zich het beste wapenen tegen de gevolgen van de economische crisis door hoge punten te behalen tijdens de studie (ROA, 2009). Scholen kunnen zich inzetten om de kans op een goede start op de arbeidsmarkt te vergroten door innovatieve curricula aan te bieden (Allen, J. et al, 2009). Meng (2005) tot slot heeft laten zien dat activerende leeromgevingen zoals probleemgestuurd onderwijs een hoog niveau van academische en vakspecifieke competenties bij universitaire afgestudeerden stimuleert, wat de overgang van universiteit naar arbeidsmarkt in economische slechte tijden vergemakkelijkt. 


\section{Literatuur}

Allen, J., et al (2009), Afgestudeerden van het hbo tijdens een crisis: geen verloren generatie, Den Haag: HBO-raad.

Meng, C. (2005), Discipline-Specific or Acamic? Acquisition, Role and Value of Higher Education Competencies, Maastricht: ROA.

Meng, C., Huijgen, T., Ramaekers, G. (2010), MBO-diploma in tijden van crisis. Doorleren of werk zoeken? ROA-R-2010/2, Maastricht: ROA.

Peschar, J., Wesselingh, A. (2001), Onderwijssociologie, Groningen: Wolters-Noordhoff.

ROA (2009), Schoolverlaters tussen onderwijs en arbeidsmarkt 2008, ROA-R-2009/4, Maastricht: ROA. 


\section{Bijlage 1: Enkele centrale begrippen}

\section{Aansluitende functie naar niveau}

Een functie wordt als aansluitend naar niveau getypeerd indien het vereiste functieniveau ten minste gelijk is aan het genoten opleidingsniveau. Het functieniveau wordt bepaald aan de hand van de door de schoolverlaters beantwoorde vraag welk opleidingsniveau volgens de werkgever minimaal werd vereist.

\section{Aansluitende functie naar richting}

Een functie wordt als aansluitend naar richting getypeerd als de vereiste opleidingsrichting gelijk of verwant is aan de genoten opleidingsrichting. De vereiste opleidingsrichting wordt bepaald aan de hand van de door de schoolverlaters beantwoorde vraag welke opleidingsrichting volgens de werkgever werd vereist.

\section{Beroepsbevolking}

Tot de beroepsbevolking behoren:

- degenen die minstens I2 uur per week werken of werk hebben aanvaard waardoor zij ten minste I2 uur per week gaan werken;

- degenen zonder werk (of met werk van minder dan i2 uur per week) die op zoek zijn naar werk.

In deze rapportage is tevens als voorwaarde gesteld dat de maatschappelijke positie niet scholier of student is.

\section{Bruto uurloon}

Het bruto uurloon heeft betrekking op de hoofdfunctie, en is inclusief toeslagen maar exclusief inkomen uit overwerk. Het bruto uurloon is gelijk aan het bruto maandloon, gedeeld door het aantal arbeidsuren per week in de hoofdfunctie, vermenigvuldigd met de factor I $2 / 52$.

\section{Deeltijdbaan}

Een deeltijdbaan betreft een aanstelling voor minder dan 33 uur per week.

\section{Flexibele arbeidsrelatie}

Een flexibele arbeidsrelatie betreft een aanstelling als uitzendkracht, oproepkracht e.d. of een aanstelling in tijdelijke dienst. 
Opleidingssector

Binnen de onderwijssoorten is een onderverdeling gemaakt naar verschillende sectoren, bijvoorbeeld techniek, economie e.d.

\section{Onderwijssoort}

In het rapport worden de gediplomeerde schoolverlaters van de volgende onderwijssoorten onderscheiden:

AVO: $\quad$ algemeen voortgezet onderwijs, HAVO en VWO.

VMBO: $\quad$ voorbereidend middelbaar beroepsonderwijs.

BOL/BBL: beroepsopleidende/beroepsbegeleidende leerweg van het secundair beroepsonderwijs. Daarbinnen wordt een onderscheid gemaakt tussen niveau I (assistent beroepsbeoefenaar $(\mathrm{AB})$ ) niveau 2 (beginnend beroepsbeoefenaar $(\mathrm{BB})$ ) niveau 3 (zelfstandig beroepsbeoefenaar (ZB)) en niveau 4 ((midden-)kaderfunctionaris $(\mathrm{M}) \mathrm{KF}$ ) of specialist).

HBO: $\quad$ hoger beroepsonderwijs.

WO: wetenschappelijk onderwijs.

\section{Werkloosheid}

In deze rapportage wordt uitgegaan van de definitie van werkloze beroepsbevolking: schoolverlaters zonder werk (of met werk van minder dan I2 uur per week) die op zoek zijn naar betaald werk. Daarbij is tevens als voorwaarde gesteld dat de maatschappelijke positie niet scholier of student is. 


\section{Bijlage 2: Kernindicatoren 1998-2009}

Kernindicatoren 1998-2009

\begin{tabular}{|c|c|c|c|c|c|c|c|c|c|c|c|c|c|}
\hline & & 1998 & 1999 & 2000 & 2001 & 2002 & 2003 & 2004 & 2005 & 2006 & 2007 & 2008 & 2009 \\
\hline \multicolumn{14}{|c|}{ Verder leren } \\
\hline AVO & $\%$ & 96 & 95 & 96 & 95 & 86 & 90 & 91 & 87 & 88 & 88 & 90 & 89 \\
\hline VMBO & $\%$ & 94 & 92 & 94 & 91 & 86 & 87 & 88 & 85 & 87 & 89 & 92 & 95 \\
\hline BOL 1 & $\%$ & * & 44 & 51 & 51 & 36 & 53 & 38 & 34 & 45 & 23 & 53 & 51 \\
\hline BOL 2 & $\%$ & 50 & 51 & 46 & 52 & 45 & 52 & 49 & 36 & 63 & 32 & 60 & 59 \\
\hline BOL 3 & $\%$ & 24 & 39 & 42 & 32 & 30 & 33 & 33 & 26 & 40 & 27 & 43 & 43 \\
\hline BOL 4 & $\%$ & 46 & 49 & 50 & 49 & 51 & 52 & 56 & 55 & 56 & 55 & 57 & 55 \\
\hline BBL 1 & $\%$ & - & - & - & - & - & - & - & - & - & 10 & 30 & 25 \\
\hline BBL 2 & $\%$ & - & - & - & - & - & - & - & - & - & 19 & 35 & 33 \\
\hline BBL 3 & $\%$ & - & - & - & - & - & - & - & - & - & 13 & 24 & 21 \\
\hline BBL 4 & $\%$ & - & - & - & - & - & - & - & - & - & 15 & 17 & 18 \\
\hline $\mathrm{HBO}$ & $\%$ & 21 & 23 & 27 & 26 & 27 & 33 & 32 & 32 & 32 & 35 & 36 & 36 \\
\hline wo & $\%$ & 25 & 29 & 26 & 27 & 27 & 29 & 31 & 30 & 30 & 32 & 35 & 31 \\
\hline
\end{tabular}

\begin{tabular}{|c|c|c|c|c|c|c|c|c|c|c|c|c|c|}
\hline \multicolumn{14}{|c|}{ Werkloosheid } \\
\hline AVO & $\%$ & 4 & 1 & * & 0 & 7 & 16 & 17 & 19 & 10 & 19 & 15 & 16 \\
\hline VMBO & $\%$ & 6 & 5 & 4 & 8 & 4 & 9 & 6 & 12 & 6 & 6 & 9 & 6 \\
\hline BOL 1 & $\%$ & $*$ & 4 & 8 & 11 & 23 & 20 & 31 & 30 & 22 & 10 & 16 & 30 \\
\hline BOL 2 & $\%$ & 5 & 2 & 5 & 7 & 5 & 15 & 23 & 17 & 11 & 8 & 8 & 12 \\
\hline BOL 3 & $\%$ & 2 & 2 & 3 & 1 & 4 & 5 & 13 & 9 & 7 & 4 & 5 & 11 \\
\hline BOL 4 & $\%$ & 3 & 2 & 3 & 2 & 4 & 4 & 10 & 7 & 6 & 3 & 3 & 6 \\
\hline BBL 1 & $\%$ & - & - & - & - & - & - & - & - & - & 5 & 1 & 9 \\
\hline BBL 2 & $\%$ & - & - & - & - & - & - & - & - & - & 3 & 1 & 3 \\
\hline BBL 3 & $\%$ & - & - & - & - & - & - & - & - & - & 0 & 1 & 3 \\
\hline BBL 4 & $\%$ & - & - & - & - & - & - & - & - & - & 2 & 1 & 1 \\
\hline $\mathrm{HBO}$ & $\%$ & 4 & 3 & 4 & 3 & 4 & 6 & 6 & 5 & 5 & 3 & 4 & 6 \\
\hline Wo & $\%$ & 3 & 3 & 3 & 3 & 3 & 5 & 5 & 4 & 4 & 3 & 4 & 5 \\
\hline
\end{tabular}

\begin{tabular}{|c|c|c|c|c|c|c|c|c|c|c|c|c|c|}
\hline \multicolumn{14}{|c|}{ Flexibele aanstelling } \\
\hline AVO & $\%$ & 32 & 28 & * & 25 & 47 & 40 & 37 & 53 & 63 & 65 & 59 & 42 \\
\hline VMBO & $\%$ & 22 & 18 & 11 & 19 & 27 & 32 & 44 & 54 & 48 & 56 & 63 & 63 \\
\hline BOL 1 & $\%$ & $*$ & 21 & 17 & 23 & 46 & 25 & 48 & 47 & 74 & 72 & 56 & 61 \\
\hline BOL 2 & $\%$ & 26 & 22 & 22 & 21 & 26 & 35 & 47 & 46 & 51 & 46 & 54 & 54 \\
\hline BOL 3 & $\%$ & 20 & 20 & 16 & 12 & 20 & 28 & 38 & 43 & 49 & 44 & 43 & 43 \\
\hline BOL 4 & $\%$ & 19 & 18 & 16 & 14 & 22 & 31 & 40 & 43 & 42 & 40 & 36 & 44 \\
\hline BBL 1 & $\%$ & - & - & - & - & - & - & - & - & - & 16 & 29 & 20 \\
\hline BBL 2 & $\%$ & - & - & - & - & - & - & - & - & - & 27 & 30 & 30 \\
\hline BBL 3 & $\%$ & - & - & - & - & - & - & - & - & - & 18 & 19 & 25 \\
\hline BBL 4 & $\%$ & - & - & - & - & - & - & - & - & - & 14 & 13 & 13 \\
\hline HBO & $\%$ & 16 & 13 & 12 & 12 & 13 & 37 & 41 & 44 & 44 & 39 & 38 & 46 \\
\hline WO & $\%$ & 14 & 10 & 9 & 9 & 11 & 50 & 52 & 52 & 51 & 46 & 50 & - \\
\hline
\end{tabular}

\begin{tabular}{|c|c|c|c|c|c|c|c|c|c|c|c|c|c|}
\hline \multicolumn{14}{|c|}{ Bruto uurloon } \\
\hline AVO & $€$ & 5.81 & 6.07 & * & 6.86 & 6.48 & 6.15 & 6.33 & 6.02 & 6.09 & 6.40 & 6.88 & 6.96 \\
\hline VMBO & $€$ & 3.91 & 4.37 & 4.20 & 4.44 & 4.66 & 4.68 & 4.54 & 4.76 & 4.91 & 4.85 & 4.85 & 4.83 \\
\hline BOL 1 & $€$ & * & 5.54 & 5.86 & 6.51 & 7.06 & 5.64 & 6.41 & 6.69 & 5.55 & 7.85 & 6.48 & 6.57 \\
\hline BOL 2 & $€$ & 5.87 & 6.10 & 6.15 & 7.20 & 6.74 & 6.54 & 6.88 & 6.94 & 6.86 & 7.60 & 7.69 & 7.85 \\
\hline BOL 3 & $€$ & 6.59 & 6.87 & 7.39 & 7.81 & 7.87 & 8.24 & 7.97 & 7.99 & 8.64 & 9.45 & 9.33 & 10.04 \\
\hline BOL 4 & $€$ & 7.42 & 7.90 & 8.15 & 8.91 & 8.44 & 8.52 & 8.68 & 8.75 & 9.45 & 10.10 & 10.19 & 10.36 \\
\hline BBL 1 & $€$ & - & - & - & - & - & - & - & - & - & 9.00 & 9.25 & 9.28 \\
\hline BBL 2 & $€$ & - & - & - & - & - & - & - & - & - & 9.80 & 9.90 & 10.12 \\
\hline BBL 3 & $€$ & - & - & - & - & - & - & - & - & - & 11.40 & 11.68 & 11.72 \\
\hline BBL 4 & $€$ & - & - & - & - & - & - & - & - & - & 12.65 & 12.81 & 13.13 \\
\hline $\mathrm{HBO}$ & $€$ & 10.19 & 10.89 & 11.37 & 11.59 & 11.90 & 12.05 & 11.70 & 11.74 & 12.68 & 13.10 & 13.79 & 13.36 \\
\hline Wo & $€$ & 11.88 & 12.00 & 13.24 & 13.29 & 13.83 & 14.06 & 14.14 & 14.39 & 14.76 & 15.60 & 15.84 & 15.76 \\
\hline
\end{tabular}


Bijlage 2: Kernindicatoren 1998-2009

\begin{tabular}{|c|c|c|c|c|c|c|c|c|c|c|c|c|c|}
\hline & & 1998 & 1999 & 2000 & 2001 & 2002 & 2003 & 2004 & 2005 & 2006 & 2007 & 2008 & 2009 \\
\hline \multicolumn{14}{|c|}{ Minimaal eigen } \\
\hline AVO & $\%$ & 64 & 60 & * & 94 & 57 & 54 & 58 & 49 & 66 & - & 63 & 54 \\
\hline VMBO & $\%$ & 79 & 74 & 71 & 79 & 84 & 87 & 87 & 87 & 87 & 60 & 88 & 86 \\
\hline BOL 1 & $\%$ & * & 23 & 25 & 30 & 32 & 52 & 44 & 29 & 68 & 60 & 59 & 57 \\
\hline BOL 2 & $\%$ & 53 & 61 & 56 & 49 & 64 & 68 & 63 & 61 & 63 & 64 & 73 & 68 \\
\hline BOL 3 & $\%$ & 69 & 62 & 73 & 64 & 65 & 75 & 65 & 64 & 77 & 79 & 84 & 76 \\
\hline BOL 4 & $\%$ & 75 & 76 & 80 & 73 & 71 & 70 & 76 & 79 & 83 & 84 & 86 & 85 \\
\hline BBL 1 & $\%$ & - & - & - & - & - & - & - & - & - & 46 & 51 & 51 \\
\hline BBL 2 & $\%$ & - & - & - & - & - & - & - & - & - & 64 & 71 & 62 \\
\hline BBL 3 & $\%$ & - & - & - & - & - & - & - & - & - & 68 & 65 & 61 \\
\hline BBL 4 & $\%$ & - & - & - & - & - & - & - & - & - & 87 & 82 & 82 \\
\hline HBO & $\%$ & 80 & 81 & 80 & 79 & 77 & 76 & 75 & 77 & 82 & 85 & 84 & 82 \\
\hline Wo & $\%$ & 62 & 63 & 66 & 66 & 66 & 64 & 63 & 61 & 65 & 64 & 67 & 67 \\
\hline
\end{tabular}

\begin{tabular}{|c|c|c|c|c|c|c|c|c|c|c|c|c|c|}
\hline \multicolumn{14}{|c|}{ Eigen/verwante richting } \\
\hline AVO & $\%$ & - & - & - & - & - & - & - & - & - & - & - & - \\
\hline VMBO & $\%$ & - & - & - & 53 & 62 & 62 & 64 & 58 & 62 & 48 & 57 & 51 \\
\hline BOL 1 & $\%$ & - & - & - & 37 & 46 & 38 & 56 & 49 & 51 & 37 & 53 & 54 \\
\hline BOL 2 & $\%$ & - & - & - & 57 & 62 & 58 & 64 & 53 & 57 & 50 & 56 & 58 \\
\hline $\mathrm{BOL} 3$ & $\%$ & - & - & - & 76 & 71 & 78 & 70 & 67 & 74 & 73 & 76 & 76 \\
\hline BOL 4 & $\%$ & - & - & - & 70 & 73 & 70 & 69 & 72 & 77 & 76 & 74 & 76 \\
\hline BBL 1 & $\%$ & - & - & - & - & - & - & - & - & - & 52 & 52 & 41 \\
\hline BBL 2 & $\%$ & - & - & - & - & - & - & - & - & - & 65 & 62 & 61 \\
\hline BBL 3 & $\%$ & - & - & - & - & - & - & - & - & - & 79 & 77 & 78 \\
\hline BBL 4 & $\%$ & - & - & - & - & - & - & - & - & - & 84 & 81 & 83 \\
\hline $\mathrm{HBO}$ & $\%$ & - & - & - & 76 & 78 & 79 & 78 & 76 & 80 & 82 & 82 & 80 \\
\hline wo & $\%$ & 72 & 71 & 71 & 71 & 73 & 71 & 72 & 70 & 74 & 74 & 71 & 73 \\
\hline
\end{tabular}

\begin{tabular}{|c|c|c|c|c|c|c|c|c|c|c|c|c|c|}
\hline \multicolumn{14}{|c|}{ Zelfde opleiding opnieuw kiezen } \\
\hline AVO & $\%$ & 79 & 82 & 83 & 81 & - & - & - & - & - & 96 & 97 & 96 \\
\hline VMBO & $\%$ & - & 79 & 79 & 80 & 76 & 86 & 84 & 85 & 88 & 84 & 81 & 82 \\
\hline BOL 1 & $\%$ & * & 65 & 55 & 69 & 68 & 55 & 60 & 63 & 66 & 61 & 67 & 68 \\
\hline BOL 2 & $\%$ & 62 & 66 & 72 & 63 & 64 & 73 & 62 & 60 & 67 & 64 & 69 & 73 \\
\hline $\mathrm{BOL} 3$ & $\%$ & 66 & 72 & 74 & 77 & 72 & 79 & 76 & 71 & 74 & 75 & 76 & 77 \\
\hline BOL 4 & $\%$ & 75 & 80 & 81 & 79 & 78 & 82 & 77 & 78 & 77 & 80 & 78 & 79 \\
\hline BBL 1 & $\%$ & - & - & - & - & - & - & - & - & - & 61 & 64 & 87 \\
\hline BBL 2 & $\%$ & - & - & - & - & - & - & - & - & - & 74 & 77 & 84 \\
\hline BBL 3 & $\%$ & - & - & - & - & - & - & - & - & - & 81 & 84 & 83 \\
\hline BBL 4 & $\%$ & - & - & - & - & - & - & - & - & - & 80 & 82 & 84 \\
\hline HBO & $\%$ & 79 & 78 & 77 & 77 & 76 & 81 & 78 & 78 & 78 & 80 & 78 & 78 \\
\hline wo & $\%$ & 81 & 81 & 82 & 80 & 80 & 83 & 81 & 81 & 82 & 83 & 83 & 86 \\
\hline
\end{tabular}


Statistische Bijlage Tabellen naar opleidingssector 
Tabellen per opleidingssector

\section{Kernindicatoren}

Ar.I Enkele kernindicatoren

2 Kenmerken van schoolverlaters

A2.I De uitstroom van schoolverlaters verbijzonderd naar geslacht, etniciteit en gemiddelde leeftijd op moment van enquête

A2.2 Vooropleiding van schoolverlaters

A2.3 Situatie op moment van enquête

3 Kwalficatie (hoe goed is men voorbereid op vervolgonderwijs of arbeidsmarkt?)

A3.I Oordeel van gediplomeerde schoolverlaters: breedte van gevolgde opleiding

A3.2 Oordeel van gediplomeerde schoolverlaters: diepgang van gevolgde opleiding

A3.3 Oordeel van gediplomeerde schoolverlaters: basis om kennis en vaardigheden verder te ontwikkelen

A3.4 Oordeel van gediplomeerde schoolverlaters: basis om te starten op arbeidsmarkt

4 Selectie (hoe streng is beoordeeld?)

A4.I Oordeel van gediplomeerde schoolverlaters: moeilijkheidsgraad van gevolgde opleiding

A4.2 Oordeel van gediplomeerde schoolverlaters: strenge beoordeling van studenten

A4.3 Oordeel van gediplomeerde schoolverlaters: uitdagend niveau 84

A4.4 Oordeel van gediplomeerde schoolverlaters: pittige tentamens/opdrachten $\quad 86$

A4.5 Oordeel van gediplomeerde schoolverlaters: toetsen op inzicht

5 Doorstroom naar vervolgonderwijs: Allocatie (waar komt men terecht?)

A5.I Doorstroom van schoolverlaters naar vervolgonderwijs 90

A5.2 Type vervolgonderwijs 92

A5.3 Belangrijkste opleidingen van schoolverlaters die een vervolgopleiding zijn gaan volgen 
A5.4 Doorstroom van schoolverlaters naar kenniscentrum beroepsonderwijs bedrijfsleven

A5.5 Oordeel van schoolverlaters over de aansluiting van de afgesloten opleiding met de vervolgopleiding

6 Doorstroom naar vervolgonderwijs: Rendement (wat levert het op?)

A6.I Uitvallers en studiewisselaars

7 Doorstroom naar vervolgonderwijs: Tevredenheid achteraf

A7.I Opleiding achteraf opnieuw kiezen

8 Intrede op de arbeidsmarkt: Allocatie (waar komt men terecht?)

A8.I Belangrijkste bedrijfsgroepen waarin schoolverlaters werkzaam zijn IOS

A8.2 Belangrijkste beroepsgroepen waarin schoolverlaters werkzaam zijn IIO

A8.3 Grootte van de organisatie waarin schoolverlaters werkzaam zijn IIs

A8.4 Vereist opleidingsniveau voor de huidige functie volgens de werkgever II7

A8.5 Vereiste opleidingsrichting voor de huidige functie volgens de werkgever II9

$\begin{array}{lll}\text { A8.6 Benutting van kennis en vaardigheden I2I } & \text { I }\end{array}$

A8.7 Kennis en vaardigheden schieten tekort $\quad$ I23

A8.8 Oordeel van de werkende schoolverlaters over de aansluiting tussen de afgesloten opleiding en de huidige functie I25

$\begin{array}{lll}\text { A8.9 Tevredenheid met huidige functie } & \text { I27 }\end{array}$

9 Intrede op de arbeidsmarkt: Rendement (wat levert het op?)

A9.I Werkloosheid $\quad$ I29

A9.2 Werkloosheid tot eerste baan I3I

A9.3 Percentage werkende schoolverlaters dat op zoek is naar een andere baan $\quad$ I33

A9.4 Aard van het dienstverband van werkende schoolverlaters $\quad$ I35

A9.5 Percentage werkende schoolverlaters met een flexibele aanstelling $\quad$ I37

$\begin{array}{ll}\text { A9.6 Beloning van werkende schoolverlaters } & \text { I39 }\end{array}$

A9.7 Percentage werkende schoolverlaters met een deeltijdaanstelling en wekelijkse arbeidsduur

A9.8 Percentage werkende schoolverlaters waarvan huidige functie goede carrièremogelijkheden biedt

Io Intrede op de arbeidsmarkt: Tevredenheid achteraf

Aro.I Opleiding achteraf opnieuw kiezen

II Aantallen en respons

AII.I Aantallen en responspercentage 


\section{Voorwoord}

In deze Statistische Bijlage bij het rapport Schoolverlaters tussen onderwijs en arbeidsmarkt 2009 wordt een overzicht gegeven van de belangrijkste resultaten van de schoolverlatersonderzoeken die door het Researchcentrum voor Onderwijs en Arbeidsmarkt (ROA) in het najaar van 2009 zijn gehouden onder schoolverlaters en afgestudeerden (VMBO, VO, MBO en HBO) van het school- of studiejaar 2007/2008. Daarnaast bevat de Statistische Bijlage deels gegevens van afgestudeerden van het WO. Deze zijn afkomstig van een onderzoek uitgevoerd door het IVA te Tilburg in opdracht van de VSNU. De gegevens bestrijken daarmee de volle breedte van het Nederlandse onderwijssysteem en hebben betrekking op de situatie van schoolverlaters en afgestudeerden ongeveer anderhalf jaar na het voltooien van de opleiding.

Voor alle getoonde gegevens geldt dat het gaat om gediplomeerde schoolverlaters en afgestudeerden. Bovendien betreft het alleen de uitstroom van voltijdopleidingen. In de statistische bijlage worden de belangrijkste gegevens per onderwijssoort en opleidingssector (bijvoorbeeld BOL niveau 2 techniek, HBO economie, WO gezondheidszorg) gepresenteerd. De tabellen uit deze statistische bijlage zijn voor het VMBO, het $\mathrm{VO}$, het $\mathrm{MBO}$ en het $\mathrm{HBO}$ ook op opleidingsniveau beschikbaar. Deze zijn te vinden op www.roa.unimaas.nl/kerncijfers.htm

Er worden alleen voor die opleidingssectoren cijfers gepresenteerd waarvan de resultaten voldoende betrouwbaar worden geacht. Daartoe is een ondergrens van 20 respondenten gehanteerd. Bij tabellen die betrekking hebben op de beroepsbevolking of op werkenden is de ondergrens gesteld op 20 respondenten die tot de beroepsbevolking behoren. Bij tabellen die betrekking hebben op vervolgopleidingen of cursussen is de ondergrens gelegd bij minimaal 20 respondenten die een vervolgopleiding respectievelijk cursus hebben gevolgd. Overigens kunnen de gepresenteerde percentages bij sommige tabellen - vanwege ontbrekende waarnemingen - op een geringer aantal respondenten zijn gebaseerd. Hiermee dient bij de interpretatie van de gegevens rekening te worden gehouden.

De opzet is als volgt: eerst worden enkele kernindicatoren gepresenteerd. Het tweede onderdeel toont enkele achtergrondkenmerken van de schoolverlaters en geeft een beschrijving van hun huidige situatie. De daaropvolgende twee onderdelen (Kwalificatie en Selectie) hebben betrekking op de gevolgde opleiding. Kwalificatie draait om de vraag of het onderwijs de schoolverlaters afdoende heeft toegerust met die competenties welke relevant zijn voor de doorstroming naar een vervolgopleiding of de arbeidsmarkt. Selectie betreft het beoordelen van studenten op de aanwezige competenties en het op grond hiervan certificeren naar eindniveau. Het vijfde tot zevende onderdeel gaat dieper in op de schoolverlaters die verder gaan leren. Eerst wordt gekeken waar men terecht is gekomen (Allocatie), daarna wordt dieper ingegaan op de vraag wat het opbrengt (Rendement) en tot slot wordt de Tevredenheid van deze groep schoolverlaters in kaart gebracht. De onderdelen acht tot en met tien gaan dieper in op de schoolverlaters die zich op de arbeidsmarkt aanbieden. Ook hier wordt eerst gekeken waar men terecht is gekomen (Allocatie), daarna wordt dieper ingegaan op de vraag wat het opbrengt (Rendement) en tot slot wordt de Tevredenheid van deze groep schoolverlaters in kaart gebracht. 
Tabel A1.1

Enkele kernindicatoren

\begin{tabular}{|c|c|c|c|c|c|c|c|c|c|}
\hline \multirow[t]{2}{*}{ Opleidingssector } & \multirow[t]{2}{*}{$\begin{array}{c}\text { benaderde } \\
\text { aantallen }\end{array}$} & \multirow[t]{2}{*}{$\begin{array}{r}\text { verder } \\
\text { leren } \\
\\
\%\end{array}$} & \multirow[t]{2}{*}{$\begin{array}{r}\text { zelfde } \\
\text { opleiding } \\
\text { opnieuw } \\
{\text { kiezen }{ }^{1)}}^{\%}\end{array}$} & \multirow{2}{*}{$\begin{array}{r}\text { werk- } \\
\text { loosheid } \\
\%\end{array}$} & \multirow{2}{*}{$\begin{array}{r}\text { intrede } \\
\text { werk- } \\
\text { loosheid } \\
\text { maanden }\end{array}$} & \multirow{2}{*}{$\begin{array}{r}\text { flexibele } \\
\text { aanstelling } \\
\%\end{array}$} & \multirow[t]{2}{*}{$\begin{array}{r}\text { bruto } \\
\text { uurloon } \\
€\end{array}$} & \multirow[t]{2}{*}{$\begin{array}{r}\text { minimaal } \\
\text { eigen } \\
\text { niveau } \\
\%\end{array}$} & \multirow[t]{2}{*}{$\begin{array}{r}\text { eigen/ } \\
\text { verwante } \\
\text { richting } \\
\%\end{array}$} \\
\hline & & & & & & & & & \\
\hline HAVO/VWO & 5.173 & 89 & 96 & 16 & $\mathbf{x}$ & 42 & 6,96 & 54 & $\mathbf{x}$ \\
\hline HAVO & 2.881 & 89 & 95 & 19 & $x$ & 40 & 6,19 & 59 & $x$ \\
\hline vWO & 2.292 & 90 & 99 & 12 & $x$ & 43 & 8,04 & 48 & $x$ \\
\hline $\begin{array}{l}\text { VMBO } \\
\text { Naar leerweg }\end{array}$ & 10.301 & 95 & 82 & 6 & 0,4 & 63 & 4,83 & 86 & 51 \\
\hline Theoretisch & 3.340 & 97 & 85 & 7 & 0,1 & 56 & 4,38 & 94 & 43 \\
\hline Gemengd & 749 & 99 & 88 & 9 & 0,5 & 77 & 5,44 & 83 & 34 \\
\hline Kaderberoepsgericht & 3.035 & 95 & 84 & 8 & 0,5 & 50 & 5,01 & 87 & 48 \\
\hline Basisberoepsgericht & 3.177 & 89 & 74 & 4 & 0,6 & 78 & 4,93 & 79 & 62 \\
\hline \multicolumn{10}{|l|}{ Naar sector } \\
\hline Landbouw & 2.434 & 95 & 82 & 6 & 0,4 & 61 & 4,68 & 88 & 63 \\
\hline Techniek & 1.293 & 92 & 82 & 2 & 0,3 & 65 & 5,34 & 82 & 60 \\
\hline Economie & 1.642 & 93 & 72 & 10 & 0,7 & 69 & 4,85 & 78 & 38 \\
\hline Gezondheidszorg & 1.592 & 94 & 82 & 7 & 0,9 & 64 & 4,65 & 86 & 54 \\
\hline MBO & 26.509 & 43 & 79 & 6 & 0,3 & 34 & 10,37 & 71 & 70 \\
\hline BOL & 19.150 & 53 & 77 & 10 & 0,5 & 46 & 9,57 & 78 & 71 \\
\hline BOL niveau 1 & 862 & 51 & 68 & 30 & 1,7 & 61 & 6,57 & 57 & 54 \\
\hline BOL niveau 2 & 3.705 & 59 & 73 & 12 & 0,4 & 54 & 7,85 & 68 & 58 \\
\hline Landbouw & 293 & 53 & 58 & 18 & 0,0 & 53 & 6,45 & 85 & 53 \\
\hline Techniek & 907 & 62 & 79 & 9 & 0,1 & 57 & 7,54 & 72 & 61 \\
\hline Economie & 1.460 & 53 & 72 & 12 & 0,5 & 50 & 8,04 & 57 & 52 \\
\hline Gezondheidszorg & 1.044 & 65 & 73 & 15 & 0,8 & 58 & 8,43 & 75 & 64 \\
\hline BOL niveau 3 & 3.923 & 43 & 77 & 11 & 0,6 & 43 & 10,04 & 76 & 76 \\
\hline Landbouw & 458 & 41 & 73 & 13 & 0,1 & 53 & 7,94 & 59 & 56 \\
\hline Techniek & 275 & 28 & 67 & - & - & - & - & - & - \\
\hline Economie & 1.217 & 55 & 71 & 18 & 0,7 & 48 & 9,60 & 70 & 74 \\
\hline Gezondheidszorg & 841 & 34 & 81 & 5 & 0,3 & 38 & 10,11 & 79 & 82 \\
\hline Gedrag en maatschappij & 1.132 & 39 & 84 & 9 & 1,1 & 46 & 10,75 & 87 & 83 \\
\hline BOL niveau 4 & 10.660 & 55 & 79 & 6 & 0,4 & 44 & 10,36 & 85 & 76 \\
\hline Landbouw & 787 & 46 & 78 & 6 & 0,3 & 55 & 9,19 & 72 & 67 \\
\hline Techniek & 3.577 & 54 & 79 & 5 & 0,3 & 46 & 10,93 & 85 & 78 \\
\hline Economie & 3.293 & 62 & 75 & 8 & 0,5 & 47 & 9,42 & 78 & 65 \\
\hline Gezondheidszorg & 1.187 & 46 & 81 & 4 & 0,2 & 36 & 10,91 & 91 & 84 \\
\hline Gedrag en maatschappij & 1.816 & 57 & 83 & 5 & 0,5 & 41 & 10,71 & 92 & 83 \\
\hline BBL & 7.359 & 26 & 84 & 3 & 0,1 & 25 & 11,09 & 64 & 69 \\
\hline BBL niveau 1 & 764 & 25 & 87 & 9 & 0,1 & 20 & 9,28 & 51 & 41 \\
\hline BBL niveau 2 & 2.702 & 33 & 84 & 3 & 0,1 & 30 & 10,12 & 62 & 61 \\
\hline Landbouw & 376 & 21 & 87 & 3 & 0,3 & 33 & 9,01 & 54 & 52 \\
\hline Techniek & 1.374 & 44 & 88 & 4 & 0,1 & 29 & 10,30 & 61 & 62 \\
\hline Economie & 667 & 21 & 71 & 3 & 0,3 & 41 & 8,96 & 58 & 50 \\
\hline Gezondheidszorg & 285 & 20 & 84 & 0 & 0,1 & 17 & 11,60 & 76 & 73 \\
\hline
\end{tabular}


Tabel A1.1

Enkele kernindicatoren

\begin{tabular}{|c|c|c|c|c|c|c|c|c|c|}
\hline \multirow[t]{2}{*}{ Opleidingssector } & \multirow[t]{2}{*}{$\begin{array}{l}\text { benaderde } \\
\text { aantallen }\end{array}$} & \multirow{2}{*}{$\begin{array}{r}\text { verder } \\
\text { leren } \\
\\
\%\end{array}$} & $\begin{array}{r}\text { zelfde } \\
\text { opleiding } \\
\text { opnieuw } \\
\text { kiezen }{ }^{1)}\end{array}$ & $\begin{array}{l}\text { werk- } \\
\text { loosheid }\end{array}$ & \multirow{2}{*}{$\begin{array}{r}\text { intrede } \\
\text { werk- } \\
\text { loosheid } \\
\text { maanden }\end{array}$} & \multirow{2}{*}{$\begin{array}{r}\text { flexibele } \\
\text { aanstelling } \\
\%\end{array}$} & \multirow{2}{*}{$\begin{array}{r}\text { bruto } \\
\text { uurloon } \\
\\
€\end{array}$} & \multirow{2}{*}{$\begin{array}{r}\text { minimaal } \\
\text { eigen } \\
\text { niveau } \\
\%\end{array}$} & \multirow[t]{2}{*}{$\begin{array}{r}\text { eigen/ } \\
\text { verwante } \\
\text { richting } \\
\%\end{array}$} \\
\hline & & & $\%$ & $\%$ & & & & & \\
\hline BBL niveau 3 & 2.681 & 21 & 83 & 3 & 0,2 & 25 & 11,72 & 61 & 78 \\
\hline Landbouw & 308 & 16 & 80 & 0 & 0,0 & 36 & 11,16 & 54 & 74 \\
\hline Techniek & 1.160 & 27 & 81 & 2 & 0,2 & 20 & 11,86 & 48 & 71 \\
\hline Economie & 516 & 26 & 72 & 10 & 0,8 & 36 & 8,56 & 52 & 69 \\
\hline Gezondheidszorg & 559 & 12 & 90 & 0 & 0,0 & 21 & 13,08 & 76 & 90 \\
\hline Gedrag en maatschappij & 138 & 16 & 90 & 4 & 0,0 & 42 & 11,89 & 100 & 96 \\
\hline BBL niveau 4 & 1.212 & 18 & 84 & 1 & 0,1 & 13 & 13,13 & 82 & 83 \\
\hline Landbouw & 88 & 26 & - & - & - & - & - & - & - \\
\hline Techniek & 274 & 25 & 83 & 0 & 0,0 & 9 & 13,96 & 67 & 84 \\
\hline Economie & 336 & 19 & 77 & 2 & 0,0 & 23 & 11,45 & 67 & 61 \\
\hline Gezondheidszorg & 295 & 15 & 87 & 1 & 0,0 & 12 & 14,32 & 95 & 91 \\
\hline Gedrag en maatschappij & 216 & 12 & 90 & 0 & 0 & 8 & 12,38 & 92 & 95 \\
\hline HBO & 39.839 & 36 & 78 & 6 & 0,9 & 46 & 13,36 & 82 & 80 \\
\hline Landbouw & 1.147 & 30 & 79 & 5 & 0,5 & 40 & 12,88 & 79 & 75 \\
\hline Onderwijs & 4.409 & 39 & 87 & 3 & 0,9 & 51 & 13,48 & 93 & 94 \\
\hline Techniek & 6.921 & 35 & 83 & 6 & 0,6 & 40 & 13,92 & 89 & 87 \\
\hline Economie & 15.520 & 41 & 71 & 8 & 1,0 & 46 & 13,17 & 80 & 65 \\
\hline Gezondheidszorg & 3.885 & 33 & 83 & 2 & 0,6 & 40 & 14,68 & 83 & 93 \\
\hline Gedrag en maatschappij & 4.977 & 30 & 77 & 4 & 0,8 & 50 & 13,66 & 68 & 88 \\
\hline Taal en cultuur & 2.980 & 23 & 85 & 9 & 1,2 & 59 & 10,43 & 78 & 82 \\
\hline wo & nb. & 31 & 86 & 5 & $\mathbf{x}$ & $x$ & 15,76 & 67 & 73 \\
\hline Landbouw & $\mathrm{nb}$. & 31 & 81 & 9 & $x$ & $x$ & 13,71 & 64 & $x$ \\
\hline Techniek & nb. & 20 & 88 & 5 & $\mathrm{x}$ & $\mathrm{x}$ & 15,92 & 69 & 78 \\
\hline Economie & $\mathrm{nb}$. & 27 & 85 & 5 & $x$ & $\mathrm{x}$ & 16,35 & 59 & 70 \\
\hline Gezondheidszorg & $\mathrm{nb}$. & 51 & 91 & 2 & $x$ & $x$ & 16,88 & 89 & 85 \\
\hline Gedrag en maatschappij & nb. & 23 & 83 & 6 & $x$ & $\mathrm{x}$ & 15,72 & 63 & 70 \\
\hline Taal en cultuur & $\mathrm{nb}$. & 32 & 81 & 8 & $\mathrm{x}$ & $\mathrm{x}$ & 14,47 & 41 & 54 \\
\hline Recht en openbare orde & nb. & 38 & 88 & 9 & $\mathrm{x}$ & $x$ & 16,34 & 79 & 81 \\
\hline Natuurwetenschappen & nb. & 41 & 83 & 2 & $x$ & $x$ & 15,02 & 69 & 80 \\
\hline Totaal & 81.822 & 63 & 84 & 6 & 0,5 & 41 & 11,02 & 74 & 70 \\
\hline
\end{tabular}

Bron: ROA (SIS);VSNU/IVA, 2009

- = te weinig waarnemingen $; \mathrm{x}=$ vraag niet opgenomen $; \mathrm{nb}=$ niet bekend

1) voor het percentage voor verder lerenden zie tabel A7.1 en voor de werkenden zie tabel A10.1

Toelichting

Deze tabel geeft een samenvattend beeld. Zie ook de tabellen A11.1, A5.1, A9.1, A9.2, A9.5, A9.6, A8.4 en A8.5. 
Tabel A2.1

De uitstroom van schoolverlaters verbijzonderd naar geslacht, etniciteit en gemiddelde leeftijd op moment van enquête

\begin{tabular}{|c|c|c|c|c|c|}
\hline Opleidingssector & $\begin{array}{r}\text { vrouw } \\
\%\end{array}$ & $\begin{array}{r}\text { westerse allochtoon } \\
\%\end{array}$ & $\begin{array}{r}\text { niet-westerse allochtoon } \\
\%\end{array}$ & $\begin{array}{r}\text { autochtoon } \\
\%\end{array}$ & $\begin{array}{l}\text { leeftijd } \\
\text { gem. }\end{array}$ \\
\hline HAVO/VWO & 53 & 6 & 8 & 86 & 19,0 \\
\hline HAVO & 53 & 5 & 7 & 88 & 18,7 \\
\hline VW0 & 54 & 8 & 8 & 84 & 19,4 \\
\hline VMBO & 49 & 5 & 12 & 83 & 17,5 \\
\hline \multicolumn{6}{|l|}{ Naarleerweg } \\
\hline Theoretisch & 50 & 5 & 7 & 88 & 17,4 \\
\hline Gemengd & 52 & 7 & 5 & 89 & 17,3 \\
\hline Kaderberoepsgericht & 48 & 5 & 13 & 81 & 17,5 \\
\hline Basisberoepsgericht & 44 & 5 & 21 & 74 & 17,7 \\
\hline \multicolumn{6}{|l|}{ Naar sector } \\
\hline Landbouw & 53 & 4 & 4 & 92 & 17,6 \\
\hline Techniek & 3 & 8 & 11 & 80 & 17,6 \\
\hline Economie & 41 & 5 & 28 & 66 & 17,7 \\
\hline Gezondheidszorg & 86 & 3 & 17 & 79 & 17,5 \\
\hline MBO & 50 & 5 & 14 & 81 & 25,1 \\
\hline BOL & 56 & 4 & 18 & 78 & 22,0 \\
\hline BOL niveau 1 & 46 & 7 & 55 & 38 & 22,0 \\
\hline BOL niveau 2 & 51 & 5 & 24 & 71 & 21,4 \\
\hline Landbouw & 48 & 0 & 2 & 98 & 20,1 \\
\hline Techniek & 12 & 2 & 20 & 78 & 22,0 \\
\hline Economie & 48 & 8 & 32 & 60 & 20,9 \\
\hline Gezondheidszorg & 90 & 5 & 21 & 74 & 21,8 \\
\hline BOL niveau 3 & 66 & 4 & 17 & 79 & 22,1 \\
\hline Landbouw & 48 & 1 & 1 & 98 & 21,1 \\
\hline Techniek & 31 & 0 & 25 & 75 & 21,9 \\
\hline Economie & 28 & 5 & 27 & 68 & 21,8 \\
\hline Gezondheidszorg & 95 & 4 & 11 & 85 & 22,7 \\
\hline Gedrag en maatschappij & 94 & 3 & 14 & 83 & 22,1 \\
\hline BOL niveau 4 & 56 & 4 & 10 & 86 & 22,3 \\
\hline Landbouw & 56 & 2 & 1 & 97 & 22,4 \\
\hline Techniek & 25 & 3 & 7 & 90 & 22,5 \\
\hline Economie & 46 & 6 & 18 & 76 & 21,9 \\
\hline Gezondheidszorg & 73 & 3 & 6 & 91 & 22,7 \\
\hline Gedrag en maatschappij & 85 & 5 & 9 & 87 & 22,4 \\
\hline BBL & 39 & 5 & 8 & 87 & 30,2 \\
\hline BBL niveau 1 & 34 & 7 & 10 & 83 & 34,3 \\
\hline BBL niveau 2 & 30 & 4 & 10 & 86 & 30,0 \\
\hline Landbouw & 18 & 7 & 6 & 87 & 29,2 \\
\hline Techniek & 6 & 3 & 8 & 90 & 28,7 \\
\hline Economie & 54 & 7 & 10 & 83 & 27,7 \\
\hline Gezondheidszorg & 88 & 6 & 18 & 76 & 38,9 \\
\hline
\end{tabular}


Tabel A2.1

De uitstroom van schoolverlaters verbijzonderd naar geslacht, etniciteit en gemiddelde leeftijd op moment van enquête

\begin{tabular}{|c|c|c|c|c|c|}
\hline Opleidingssector & $\begin{array}{r}\text { vrouw } \\
\%\end{array}$ & $\begin{array}{r}\text { westerse allochtoon } \\
\%\end{array}$ & $\begin{array}{r}\text { niet-westerse allochtoon } \\
\%\end{array}$ & $\begin{array}{r}\text { autochtoon } \\
\%\end{array}$ & $\begin{array}{l}\text { leeftijd } \\
\text { gem. }\end{array}$ \\
\hline BBL niveau 3 & 43 & 5 & 6 & 89 & 28,7 \\
\hline Landbouw & 34 & 5 & 3 & 92 & 26,2 \\
\hline Techniek & 3 & 3 & 7 & 90 & 25,5 \\
\hline Economie & 46 & 5 & 3 & 92 & 23,1 \\
\hline Gezondheidszorg & 92 & 7 & 5 & 88 & 35,3 \\
\hline Gedrag en maatschappij & 93 & 6 & 19 & 75 & 36,6 \\
\hline BBL niveau 4 & 58 & 6 & 7 & 87 & 31,0 \\
\hline Landbouw & 35 & 4 & 4 & 92 & 29,9 \\
\hline Techniek & 11 & 7 & 5 & 88 & 29,6 \\
\hline Economie & 45 & 11 & 10 & 80 & 28,6 \\
\hline Gezondheidszorg & 83 & 0 & 5 & 95 & 31,5 \\
\hline Gedrag en maatschappij & 83 & 9 & 14 & 77 & 34,5 \\
\hline HBO & 55 & 8 & 7 & 85 & 24,8 \\
\hline Landbouw & 39 & 4 & 2 & 94 & 24,7 \\
\hline Onderwijs & 81 & 4 & 4 & 92 & 24,8 \\
\hline Techniek & 11 & 6 & 6 & 88 & 24,9 \\
\hline Economie & 49 & 10 & 10 & 81 & 24,6 \\
\hline Gezondheidszorg & 82 & 9 & 4 & 88 & 24,7 \\
\hline Gedrag en maatschappij & 86 & 5 & 7 & 88 & 24,5 \\
\hline Taal en cultuur & 65 & 23 & 7 & 70 & 26,7 \\
\hline Wo & 56 & 12 & 8 & 80 & 27,1 \\
\hline Landbouw & 57 & 19 & 19 & 62 & 27,5 \\
\hline Techniek & 22 & 8 & 8 & 84 & 27,2 \\
\hline Economie & 33 & 16 & 11 & 73 & 26,3 \\
\hline Gezondheidszorg & 73 & 9 & 6 & 84 & 27,0 \\
\hline Gedrag en maatschappij & 76 & 12 & 6 & 82 & 26,7 \\
\hline Taal en cultuur & 67 & 13 & 5 & 82 & 28,4 \\
\hline Recht en openbare orde & 56 & 13 & 10 & 77 & 27,5 \\
\hline Natuurwetenschappen & 43 & 13 & 8 & 79 & 26,8 \\
\hline Totaal & 51 & 6 & 11 & 83 & 22,1 \\
\hline
\end{tabular}

Bron: ROA (SIS); VSNU/IVA, 2009

Toelichting

Het betreft de leeftijd per onderzoeksdatum ongeveer anderhalf jaar na schoolverlaten. 
Tabel A2.2

Vooropleiding van schoolverlaters

\begin{tabular}{|c|c|c|c|c|c|c|}
\hline Opleidingssector & $\begin{array}{r}\text { MAVO } \\
\%\end{array}$ & $\begin{array}{r}\text { HAVO } \\
\%\end{array}$ & $\begin{array}{r}\text { VW0 } \\
\%\end{array}$ & $\begin{array}{r}\text { MBO } \\
\%\end{array}$ & $\begin{array}{r}\mathrm{HBO} \\
\%\end{array}$ & $\begin{array}{r}\text { overig } \\
\%\end{array}$ \\
\hline HBO & 1 & 49 & 16 & 27 & 5 & 3 \\
\hline Landbouw & 1 & 38 & 13 & 43 & 4 & 1 \\
\hline Onderwijs & 1 & 56 & 13 & 23 & 6 & 1 \\
\hline Techniek & 0 & 45 & 14 & 35 & 3 & 2 \\
\hline Economie & 0 & 52 & 17 & 25 & 3 & 3 \\
\hline Gezondheidszorg & 0 & 50 & 21 & 21 & 5 & 4 \\
\hline Gedrag en maatschappij & 1 & 51 & 11 & 33 & 3 & 2 \\
\hline Taal en cultuur & 2 & 27 & 29 & 15 & 17 & 10 \\
\hline wo & 0 & 3 & 58 & 0 & 22 & 16 \\
\hline Landbouw & 0 & 9 & 59 & 0 & 9 & 22 \\
\hline Techniek & 0 & 3 & 72 & 0 & 19 & 6 \\
\hline Economie & 0 & 3 & 51 & 0 & 31 & 16 \\
\hline Gezondheidszorg & 0 & 2 & 68 & 0 & 12 & 18 \\
\hline Gedrag en maatschappij & 0 & 3 & 50 & 0 & 32 & 15 \\
\hline Taal en cultuur & 0 & 4 & 49 & 0 & 21 & 25 \\
\hline Recht en openbare orde & 0 & 5 & 56 & 0 & 17 & 22 \\
\hline Natuurwetenschappen & 0 & 5 & 72 & 0 & 13 & 11 \\
\hline Totaal & 0 & 35 & 29 & 19 & 10 & 7 \\
\hline
\end{tabular}

Bron: ROA (SIS);VSNU/IVA, 2009 
Tabel A2.3

Situatie op moment van enquête

$\begin{array}{lrrrr}\text { Opleidingssector } & \text { studie } & \begin{array}{c}\text { combinatie } \\ \text { werk-leren }\end{array} & \text { betaald werk } & \text { anders } \\ & \% & \% & \% & \% \\ \text { HAV0/NW0 } & \mathbf{8 6} & \mathbf{9} & \mathbf{3} & \mathbf{2} \\ \text { HAV0 } & 84 & 10 & 4 & 2 \\ \text { VW0 } & 89 & 8 & 2 & \mathbf{4} \\ \text { VMBO } & \mathbf{6 6} & \mathbf{2 5} & \mathbf{5} & 3 \\ \text { Naarleerweg } & & & 2 & 0 \\ \text { Theoretisch } & 76 & 19 & 2 & 4 \\ \text { Gemengd } & 78 & 20 & 6 & 6 \\ \text { Kaderberoepsgericht } & 62 & 28 & 12 & \\ \text { Basisberoepsgericht } & 48 & 34 & & \end{array}$

\begin{tabular}{|c|c|c|c|c|}
\hline \multicolumn{5}{|l|}{ Naar sector } \\
\hline Landbouw & 57 & 31 & 8 & 4 \\
\hline Techniek & 46 & 40 & 8 & 6 \\
\hline Economie & 63 & 26 & 8 & 3 \\
\hline Gezondheidszorg & 63 & 24 & 8 & 5 \\
\hline MBO & 25 & 21 & 48 & 6 \\
\hline BOL & 38 & 18 & 37 & 6 \\
\hline BOL niveau 1 & 38 & 30 & 21 & 10 \\
\hline BOL niveau 2 & 38 & 27 & 27 & 8 \\
\hline Landbouw & 27 & 26 & 34 & 14 \\
\hline Techniek & 29 & 37 & 25 & 9 \\
\hline Economie & 37 & 31 & 25 & 8 \\
\hline Gezondheidszorg & 49 & 16 & 30 & 6 \\
\hline BOL niveau 3 & 26 & 17 & 49 & 8 \\
\hline Landbouw & 23 & 18 & 50 & 8 \\
\hline Techniek & 17 & 10 & 64 & 10 \\
\hline Economie & 37 & 18 & 37 & 8 \\
\hline Gezondheidszorg & 18 & 20 & 53 & 8 \\
\hline Gedrag en maatschappij & 22 & 12 & 57 & 9 \\
\hline BOL niveau 4 & 44 & 13 & 39 & 4 \\
\hline Landbouw & 40 & 7 & 45 & 8 \\
\hline Techniek & 47 & 10 & 40 & 4 \\
\hline Economie & 49 & 16 & 31 & 4 \\
\hline Gezondheidszorg & 35 & 15 & 46 & 5 \\
\hline Gedrag en maatschappij & 43 & 10 & 43 & 4 \\
\hline BBL & 2 & 26 & 67 & 6 \\
\hline BBL niveau 1 & 4 & 22 & 62 & 13 \\
\hline BBL niveau 2 & 1 & 33 & 61 & 5 \\
\hline Landbouw & 0 & 29 & 68 & 2 \\
\hline Techniek & 1 & 38 & 57 & 4 \\
\hline Economie & 4 & 23 & 65 & 8 \\
\hline Gezondheidszorg & 2 & 31 & 66 & 2 \\
\hline
\end{tabular}


Tabel A2.3

Situatie op moment van enquête

\begin{tabular}{|c|c|c|c|}
\hline Opleidingssector & studie & $\begin{array}{l}\text { combinatie } \\
\text { werk-leren }\end{array}$ & betaald werk \\
\hline & $\%$ & $\%$ & $\%$ \\
\hline
\end{tabular}

$\begin{array}{llllr}\text { BBL niveau 3 } & \mathbf{1} & \mathbf{2 2} & \mathbf{7 1} & \mathbf{6} \\ \text { Landbouw } & 0 & 19 & 81 & 0 \\ \text { Techniek } & 1 & 28 & 65 & 6 \\ \text { Economie } & 5 & 17 & 67 & 11 \\ \text { Gezondheidszorg } & 1 & 15 & 79 & 5 \\ \text { Gedrag en maatschappij } & 0 & 19 & 71 & 10\end{array}$

Gedrag en maatschappij

$\begin{array}{llll}\mathbf{3} & \mathbf{1 7} & \mathbf{7 5} & \mathbf{5} \\ 4 & 13 & 75 & 8 \\ 2 & 20 & 73 & 5 \\ 4 & 21 & 75 & 0 \\ 3 & 18 & 74 & 5 \\ 2 & 10 & 79 & 9\end{array}$

$\begin{array}{ll}\text { HBO } & 17\end{array}$

Landbouw

Onderwijs

Techniek

Economie

Gezondheidszorg

Gedrag en maatschappij

Taal en cultuur

17
16
9
21
22
9
12
9

1
0
0
0
0
0
0
11

71

Totaal

47

17

Bron: ROA (SIS)

$\begin{array}{rrr}\mathbf{1} & \mathbf{7 1} & \mathbf{1 2} \\ 0 & 76 & 8 \\ 0 & 76 & 15 \\ 0 & 70 & 8 \\ 0 & 66 & 13 \\ 0 & 80 & 11 \\ 0 & 77 & 10 \\ 11 & 67 & 12 \\ \mathbf{1 7} & & \mathbf{5}\end{array}$


Tabel A3.1

Oordeel van gediplomeerde schoolverlaters: breedte van gevolgde opleiding

$\begin{array}{lcr}\text { Opleidingssector } & \begin{array}{r}\text { te smal } \\ \%\end{array} & \begin{array}{r}\text { te breed } \\ \%\end{array} \\ \text { HAVO/VWO } & 2 & \mathbf{9} \\ \text { HAVO } & 2 & 7 \\ \text { VWO } & 2 & 10 \\ \text { VMBO } & & \mathbf{8} \\ \text { Naarleerweg } & \mathbf{8} & 6 \\ \text { Theoretisch } & & 8 \\ \text { Gemengd } & 7 & 9 \\ \text { Kaderberoepsgericht } & 8 & 72\end{array}$

\begin{tabular}{lrr} 
Naar sector & & 7 \\
Landbouw & 10 & 9 \\
Techniek & 6 & 11 \\
Economie & 10 & 10 \\
Gezondheidszorg & 7 & $\mathbf{1 0}$ \\
MBO & $\mathbf{7}$ & $\mathbf{1 1}$ \\
\hline BOL & & $\mathbf{1 4}$ \\
BOL niveau 1 & $\mathbf{8}$ & $\mathbf{1 2}$ \\
& & 19 \\
BOL niveau 2 & $\mathbf{5}$ & 16 \\
Landbouw & & 7 \\
Techniek & $\mathbf{7}$ & 15 \\
Economie & 5 & 9 \\
Gezondheidszorg & 6 & 6 \\
\hline
\end{tabular}

$\begin{array}{lrr}\text { BOL niveau 3 } & \mathbf{1 0} & \mathbf{9} \\ \text { Landbouw } & 10 & 5 \\ \text { Techniek } & 26 & 1 \\ \text { Economie } & 11 & 5 \\ \text { Gezondheidszorg } & 5 & 8 \\ \text { Gedrag en maatschappij } & 11 & 15\end{array}$

BOL niveau 4

Landbouw

$7 \quad 11$

Techniek

Economie

Gezondheidszorg

Gedrag en maatschappij

BBL

6

10

BBL niveau 1

6

12

BBL niveau 2

Landbouw

Techniek

Economie

Gezondheidszorg

$\begin{array}{rr}6 & 9 \\ 7 & 14 \\ 4 & 6 \\ 13 & 15 \\ 4 & 14\end{array}$

BBL niveau 3

Landbouw

Techniek

Economie

Gezondheidszorg

Gedrag en maatschappij

$\begin{array}{rr}6 & \mathbf{1 0} \\ 9 & 3 \\ 3 & 9 \\ 14 & 7 \\ 6 & 14 \\ 10 & 13\end{array}$


Tabel A3.1

Oordeel van gediplomeerde schoolverlaters: breedte van gevolgde opleiding

$\begin{array}{lrr}\text { Opleidingssector } & \text { te smal } & \text { te breed } \\ & \% & \%\end{array}$

$\begin{array}{lr}\text { BBL niveau } 4 & 7\end{array}$

Landbouw

Techniek

Economie

Gezondheidszorg

Gedrag en maatschappij

HBO

Landbouw

Onderwijs

Techniek

Economie

Gezondheidszorg

Gedrag en maatschappij

Totaal

Bron: ROA (SIS)

\section{Toelichting}

Vraag in de enquête:

Wat is uw oordeel over uw gevolgde opleiding met betrekking tot de breedte van de opleiding ( 1 'te weinig' tot 7 'te veel').

Vermeld is percentage van antwoordcategorie 1 en 2 (te smal) en antwoordcategorie 6 en 7 (te breed). 
Tabel A3.2

Oordeel van gediplomeerde schoolverlaters: diepgang van gevolgde opleiding

$\begin{array}{lr}\text { Opleidingssector } & \text { te weinig diepgang } \\ \%\end{array}$

$\begin{array}{lr}\text { HAVO/VWO } & 9 \\ \text { HAVO } & 8 \\ \text { VWO } & 11\end{array}$

VMBO

Naar leerweg

Theoretisch

Gemengd

Kaderberoepsgericht

Basisberoepsgericht

$\begin{array}{lr}\text { Naar sector } & 10 \\ \text { Landbouw } & 8 \\ \text { Techniek } & 11 \\ \text { Economie } & 12 \\ \text { Gezondheidszorg } & 12\end{array}$

MBO

BOL

BOL niveau 1

BOL niveau 2

Techniek

Economie

Gezondheidszorg

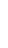
1

BOL niveau 3

\begin{tabular}{ll}
17 & 17 \\
\hline
\end{tabular}

$\begin{array}{ll}\text { Techniek } & 39\end{array}$

Economie

Gezondheidszorg 12

Gedrag en maatschappij 19

BoL niveau $4 \quad 24$

Landbouw

Techniek 25

Economie $\quad 22$

Gezondheidszorg

Gedrag en maatschappij

BBL

BBL niveau 1

BBL niveau 2

Landbouw

Techniek

Economie

Gezondheidszorg

BBL niveau 3

Landbouw

Techniek

Economie

Gezondheidszorg

Gedrag en maatschappij 
Tabel A3.2

Oordeel van gediplomeerde schoolverlaters: diepgang van gevolgde opleiding Opleidingssector

\section{BBL niveau 4}

Landbouw

Techniek

Economie

Gezondheidszorg

Gedrag en maatschappij

\section{HBO}

Landbouw

Onderwijs

Techniek

Economie

Gedrag en maatschappij

Totaal

Bron: ROA (SIS)

\section{Toelichting}

Vraag in de enquête:

Wat is uw oordeel over uw gevolgde opleiding met betrekking tot de diepgang van de opleiding ( 1 'te weinig' tot 7 'te veel'). Vermeld is percentage van antwoordcategorie 1 en 2 (te weinig). 
Tabel A3.3

Oordeel van gediplomeerde schoolverlaters: basis om kennis en vaardigheden verder te ontwikkelen Opleidingssector

\section{VMBO}

Naar leerweg

Theoretisch

Gemengd

Kaderberoepsgericht

Basisberoepsgericht

Naar sector

Landbouw

Techniek

BOL

BOL niveau 1

BOL niveau 2

Techniek

Economie

Gezondheidszorg

BOL niveau 3

Techniek

Economie

Gezondheidszorg

Gedrag en maatschappij

B0L niveau 4

Techniek

Economie

Gezondheidszorg

Gedrag en maatschappij

BBL niveau 1

BBL niveau 2

Landbouw

Techniek

Economie

BBL niveau 3

Landbouw

Economie 
Tabel A3.3

Oordeel van gediplomeerde schoolverlaters: basis om kennis en vaardigheden verder te ontwikkelen Opleidingssector

BBL niveau 4

Landbouw

Techniek

Economie

Gezondheidszorg

Gedrag en maatschappi

HBO

Landbouw

Onderwijs

Techniek

Economie

Gezondheidszorg

Gedrag en maatschappij

72

Taal en cultuur

Totaal

Bron: ROA (SIS)

Toelichting

In welke mate biedt uw gevolgde opleiding een goede basis om kennis en vaardigheden verder te ontwikkelen ( 1 'helemaal niet' tot 5 'in sterkte mate'). Vermeld is het percentage van antwoordcategorie 4 en 5. 
Tabel A3.4

Oordeel van gediplomeerde schoolverlaters: basis om te starten op arbeidsmarkt Opleidingssector

\section{VMBO}

Naarleerweg

Theoretisch

Gemengd

Kaderberoepsgericht

Basisberoepsgericht

$\begin{array}{lr}\text { Naar sector } & 23 \\ \text { Landbouw } & 33 \\ \text { Techniek } & 33 \\ \text { Economie } & 29 \\ \text { Gezondheidszorg } & 29\end{array}$

MBO

BOL

B0L niveau 1

BOL niveau 2

Landbouw

Techniek

Economie

Gezondheidszorg

BOL niveau 3

Landbouw

Techniek

Economie

Gezondheidszorg

Gedrag en maatschappij

BOL niveau 4

Landbouw

Techniek

Economie

Gezondheidszorg

Gedrag en maatschappij

BBL

BBL niveau 1

BBL niveau 2

Landbouw

Techniek

Economie

Gezondheidszorg

BBL niveau 3

Landbouw

Techniek

Economie

Gezondheidszorg

Gedrag en maatschappij 
Tabel A3.4

Oordeel van gediplomeerde schoolverlaters: basis om te starten op arbeidsmarkt Opleidingssector

BBL niveau 4

Landbouw

Techniek

Economie

Gezondheidszorg

Gedrag en maatschappij

HBO

Landbouw

Onderwijs

Techniek

Economie

Gezondheidszorg

Gedrag en maatschappij

Taal en cultuur

Totaal

Bron: ROA (SIS)

\section{Toelichting}

Vraag in de enquête:

In welke mate biedt uw gevolgde opleiding een goede basis om te starten op de arbeidsmarkt ( 1 'helemaal niet' tot 5 'in sterke mate'). Vermeld is het percentage van antwoordcategorie 4 en 5. 
Tabel A4.1

Oordeel van gediplomeerde schoolverlaters: moeilijkheidsgraad van gevolgde opleiding

\begin{tabular}{|c|c|c|}
\hline Opleidingssector & $\begin{array}{r}\text { te makkelijk } \\
\%\end{array}$ & $\begin{array}{r}\text { te moeilijk } \\
\%\end{array}$ \\
\hline HAVO/VWO & 10 & 4 \\
\hline HAVO & 8 & 3 \\
\hline VWo & 12 & 4 \\
\hline VMBO & 18 & 4 \\
\hline Naar leerwea & & \\
\hline Theoretisch & 22 & 3 \\
\hline Gemengd & 15 & 3 \\
\hline Kaderberoepsgericht & 16 & 4 \\
\hline Basisberoepsgericht & 14 & 5 \\
\hline Naar sector & & \\
\hline Landbouw & 17 & 2 \\
\hline Techniek & 18 & 3 \\
\hline Economie & 15 & 5 \\
\hline Gezondheidszorg & 12 & 6 \\
\hline MBO & 19 & 7 \\
\hline BOL & 22 & 6 \\
\hline BOL niveau 1 & 13 & 20 \\
\hline BOL niveau 2 & 16 & 10 \\
\hline Landbouw & 13 & 8 \\
\hline Techniek & 13 & 14 \\
\hline Economie & 21 & 7 \\
\hline Gezondheidszorg & 12 & 11 \\
\hline BOL niveau 3 & 16 & 6 \\
\hline Landbouw & 16 & 8 \\
\hline Techniek & 26 & 7 \\
\hline Economie & 21 & 5 \\
\hline Gezondheidszorg & 9 & 4 \\
\hline Gedrag en maatschappij & 16 & 6 \\
\hline BOL niveau 4 & 28 & 4 \\
\hline Landbouw & 27 & 2 \\
\hline Techniek & 31 & 5 \\
\hline Economie & 28 & 4 \\
\hline Gezondheidszorg & 23 & 4 \\
\hline Gedrag en maatschappij & 30 & 2 \\
\hline BBL & 14 & 7 \\
\hline BBL niveau 1 & 11 & 7 \\
\hline BBL niveau 2 & 14 & 10 \\
\hline Landbouw & 23 & 0 \\
\hline Techniek & 10 & 11 \\
\hline Economie & 21 & 9 \\
\hline Gezondheidszorg & 14 & 14 \\
\hline BBL niveau 3 & 14 & 5 \\
\hline Landbouw & 25 & 6 \\
\hline Techniek & 8 & 7 \\
\hline Economie & 26 & 5 \\
\hline Gezondheidszorg & 14 & 2 \\
\hline Gedrag en maatschappij & 17 & \\
\hline
\end{tabular}


Tabel A4.1

Oordeel van gediplomeerde schoolverlaters: moeilijkheidsgraad van gevolgde opleiding

Opleidingssector te makkelijk

\% $\quad$ te moeilijk

BBL niveau 4

Landbouw

Techniek

Economie

Gezondheidszorg

Gedrag en maatschappij

$\begin{array}{rr}\mathbf{1 4} & \mathbf{4} \\ 4 & 8 \\ 13 & 8 \\ 17 & 4 \\ 11 & 1 \\ 22 & 7\end{array}$

HBO

$20 \quad 3$

Landbouw

Onderwijs

Techniek

Economie

Gezondheidszorg

Gedrag en maatschappij

Totaal

Bron: ROA (SIS)

\section{Toelichting}

Vraag in de enquête:

Wat is uw oordeel over uw gevolgde opleiding met betrekking tot de moeilijkheidsgraad van de opleiding ( 1 'veel te laag' tot 7 'veel te hoog'). Vermeld is het percentage van antwoordcategorie 1 en 2 (te makkelijk) en 6 en 7 (te moeilijk). 
Tabel A4.2

Oordeel van gediplomeerde schoolverlaters: strenge beoordeling van studenten $\begin{array}{ll}\text { Opleidingssector } & \text { (helemaal) mee }\end{array}$ eens
$\%$

$\begin{array}{rr}\text { mee } & \text { (helemaal) mee } \\ \% & \text { oneens } \\ \% & \%\end{array}$

\begin{tabular}{lcc} 
HAVO/VWO & $\mathbf{3 2}$ \\
HAVO & $\mathbf{2 6}$ & 31 \\
VWO & 24 & 34 \\
& 28 & $\mathbf{3 5}$ \\
VMBO & & 37 \\
Naar leerweg & $\mathbf{2 1}$ & 46 \\
Theoretisch & & 35 \\
Gemengd & 19 & 35 \\
Kaderberoepsgericht & 11 & 32 \\
Basisberoepsgericht & 22 & 26 \\
\hline
\end{tabular}

\begin{tabular}{lll} 
Naar sector & & 40 \\
Landbouw & 16 & 30 \\
Techniek & 28 & 40 \\
Economie & 20 & 31 \\
Gezondheidszorg & 23 & $\mathbf{4 4}$ \\
MBO & $\mathbf{1 7}$ & $\mathbf{4 3}$ \\
\hline BOL & & $\mathbf{3 6}$ \\
BOL niveau 1 & $\mathbf{1 8}$ & $\mathbf{3 4}$ \\
BOL niveau 2 & $\mathbf{2 5}$ & 33 \\
Landbouw & & 34 \\
Techniek & $\mathbf{2 1}$ & 33 \\
Economie & 21 & 36 \\
Gezondheidszorg & 21 & 26 \\
\hline
\end{tabular}

BOL niveau 3

$\begin{array}{lcc}\text { Landbouw } & 19 & 41 \\ \text { Techniek } & 10 & 42 \\ \text { Economie } & 14 & 49 \\ \text { Gezondheidszorg } & 15 & 51 \\ \text { Gedrag en maatschappij } & 26 & 29 \\ \end{array}$

$\begin{array}{lcr}\text { BOL niveau 4 } & \mathbf{1 6} & \mathbf{4 9} \\ \text { Landbouw } & 11 & 58 \\ \text { Techniek } & 18 & 49 \\ \text { Economie } & 14 & 49 \\ \text { Gezondheidszorg } & 18 & 44 \\ \text { Gedrag en maatschappij } & 16 & 49 \\ \text { BBL } & & \mathbf{4 5} \\ \text { BBL niveau 1 } & \mathbf{1 6} & \mathbf{4 4} \\ \text { BBL niveau 2 } & \mathbf{1 9} & \mathbf{4 3} \\ \text { Landbouw } & & 44 \\ \text { Techniek } & \mathbf{1 7} & 46 \\ \text { Economie } & 6 & 38 \\ \text { Gezondheidszorg } & 14 & 41\end{array}$


Tabel A4.2

Oordeel van gediplomeerde schoolverlaters: strenge beoordeling van studenten Opleidingssector

(helemaal) mee

(helemaal) mee

oneens

eens

BBL niveau 3

Landbouw

Techniek

Economie

Gezondheidszorg

Gedrag en maatschappij

16

BBL niveau 4

Landbouw

Techniek

Economie

Gezondheidszorg

Gedrag en maatschappij

$\begin{array}{ll}19 & 38 \\ 14 & 43 \\ 16 & 52 \\ 16 & 44 \\ 19 & 58\end{array}$

HBO

Landbouw

Onderwijs

Techniek

Economie

Gezondheidszorg

Gedrag en maatschappij

$\begin{array}{rr}\mathbf{1 2} & \mathbf{5 0} \\ 21 & 58 \\ 13 & 36 \\ 13 & 50 \\ 9 & 54 \\ 14 & 51\end{array}$

Totaal

Bron: ROA (SIS)

$17 \quad 42$

$15 \quad 39$

$16 \quad 43$

$16 \quad 45$

$17-43$

$21 \quad 35$

$20 \quad 39$

Toelichting

Vraag in de enquête:

De docenten waren streng in de beoordeling van cursisten ( 1 'helemaal mee oneens' tot 5 'helemaal mee eens'). Vermeld is het percentage van antwoordcategorie 4 en 5 (helemaal mee eens) en 1 en 2 (helemaal mee oneens). 
Tabel A4.3

Oordeel van gediplomeerde schoolverlaters: uitdagend niveau

$\begin{array}{ll}\text { Opleidingssector } & \text { (helemaal) mee eens } \\ \text { HAVO/VWO } & \\ \text { HAVO } \\ \text { VWO } \\ \text { VMBO } \\ \text { Naarleerweg } \\ \text { Theoretisch } \\ \text { Gemengd } \\ \text { Kaderberoepsgericht } \\ \text { Basisberoepsgericht }\end{array}$

$\begin{array}{rr}\begin{array}{r}\text { eens } \\ \%\end{array} & \text { (helemaal) mee oneens } \\ & \% \\ \mathbf{3 7} & \mathbf{3 3} \\ 32 & 37 \\ 44 & 28 \\ & \\ \mathbf{2 6} & \mathbf{3 8} \\ & \\ 22 & 44 \\ 26 & 40 \\ 28 & 33 \\ 30 & 33\end{array}$

Naar sector
Landbouw
Techniek
Economie
Gezondheidszorg
MBO
BOL
BOL niveau 1
B0L niveau 2
Landbouw
Techniek
Economie
Gezondheidszorg
B0L niveau 3
Landbouw
Techniek
Economie
Gezondheidszorg
Gedrag en maatschappij

\begin{tabular}{lcc} 
BOL niveau 4 & $\mathbf{2 7}$ & $\mathbf{4 5}$ \\
Landbouw & 26 & 44 \\
Techniek & 30 & 46 \\
Economie & 25 & 47 \\
Gezondheidszorg & 31 & 38 \\
Gedrag en maatschappij & 25 & 45 \\
BBL & & $\mathbf{3 0}$ \\
BBL niveau 1 & $\mathbf{3 6}$ & $\mathbf{2 9}$ \\
& & $\mathbf{2 7}$ \\
BBL niveau 2 & $\mathbf{4 1}$ & 28 \\
Landbouw & & 25 \\
Techniek & $\mathbf{3 8}$ & 35 \\
Economie & 35 & 25 \\
Gezondheidszorg & 36 & $\mathbf{3 1}$ \\
& 36 & 43 \\
BBL niveau 3 & 36 \\
Landbouw & 49 & 30 \\
Techniek & & 44 \\
Economie & $\mathbf{3 5}$ & 25 \\
Gezondheidszorg & 30 & 22 \\
Gedrag en maatschappij & 32 & 29 \\
\hline
\end{tabular}


Tabel A4.3

Oordeel van gediplomeerde schoolverlaters: uitdagend niveau

$\begin{array}{lrr}\text { Opleidingssector } & \text { (helemaal) mee eens } & \text { (helemaal) mee oneens } \\ \% & \%\end{array}$

$\begin{array}{lr}\text { BBL niveau } 4 & 30\end{array}$

Landbouw

$\begin{array}{ll}\text { Techniek } & 42\end{array}$

Economie $\quad 19$

Gezondheidszorg

Gedrag en maatschappij

HBO

$33-35$

Landbouw

Onderwijs

Techniek

Economie

Gedrag en maatschappij

30

Totaal

31

Bron: ROA (SIS)

\section{Toelichting}

Vraag in de enquête:

De opleiding was uitdagend met betrekking tot niveau ( 1 'helemaal mee oneens' tot 5 'helemaal mee eens'). Vermeld is het percentage van antwoordcategorie 4 en 5 (helemaal mee eens) en 1 en 2 (helemaal mee oneens). 
Tabel A4.4

Oordeel van gediplomeerde schoolverlaters: pittige tentamens/opdrachten

\begin{tabular}{lcr} 
Opleidingssector & $\begin{array}{r}\text { (helemaal) mee eens } \\
\%\end{array}$ & $\begin{array}{r}\text { (helemaal) mee oneens } \\
\%\end{array}$ \\
HAVONWO & $\mathbf{3 0}$ & $\mathbf{3 4}$ \\
HAVO & 26 & 37 \\
VWO & 35 & 31 \\
VMBO & & $\mathbf{3 8}$ \\
Naar leerweg & $\mathbf{2 5}$ & 41 \\
Theoretisch & & 34 \\
Gemengd & 23 & 35 \\
Kaderberoepsgericht & 28 & 37 \\
Basisberoepsgericht & 27 & 24 \\
\hline
\end{tabular}

\begin{tabular}{|c|c|c|}
\hline \multicolumn{3}{|l|}{ Naar sector } \\
\hline Landbouw & 27 & 36 \\
\hline Techniek & 24 & 35 \\
\hline Economie & 22 & 44 \\
\hline Gezondheidszorg & 29 & 30 \\
\hline MBO & 26 & 36 \\
\hline BOL & 24 & 39 \\
\hline BOL niveau 1 & 31 & 25 \\
\hline BOL niveau 2 & 30 & 32 \\
\hline Landbouw & 16 & 36 \\
\hline Techniek & 42 & 23 \\
\hline Economie & 32 & 35 \\
\hline Gezondheidszorg & 21 & 33 \\
\hline BOL niveau 3 & 27 & 35 \\
\hline Landbouw & 23 & 28 \\
\hline Techniek & 29 & 46 \\
\hline Economie & 25 & 41 \\
\hline Gezondheidszorg & 35 & 26 \\
\hline Gedrag en maatschappij & 23 & 38 \\
\hline BOL niveau 4 & 19 & 46 \\
\hline Landbouw & 15 & 53 \\
\hline Techniek & 21 & 44 \\
\hline Economie & 20 & 46 \\
\hline Gezondheidszorg & 22 & 44 \\
\hline Gedrag en maatschappij & 17 & 49 \\
\hline BBL & 30 & 29 \\
\hline BBL niveau 1 & 28 & 29 \\
\hline BBL niveau 2 & 35 & 25 \\
\hline Landbouw & 24 & 25 \\
\hline Techniek & 34 & 23 \\
\hline Economie & 34 & 27 \\
\hline Gezondheidszorg & 42 & 28 \\
\hline BBL niveau 3 & 28 & 32 \\
\hline Landbouw & 23 & 38 \\
\hline Techniek & 34 & 29 \\
\hline Economie & 28 & 42 \\
\hline Gezondheidszorg & 25 & 29 \\
\hline Gedrag en maatschappij & 16 & 42 \\
\hline
\end{tabular}


Tabel A4.4

Oordeel van gediplomeerde schoolverlaters: pittige tentamens/opdrachten

$\begin{array}{lcr}\text { Opleidingssector } & \text { (helemaal) mee eens } & \text { (helemaal) mee oneens } \\ & \% & \\ \text { BBL niveau 4 } & & \mathbf{3 5} \\ \text { Landbouw } & \mathbf{2 4} & 30 \\ \text { Techniek } & 40 & 23 \\ \text { Economie } & 37 & 35 \\ \text { Gezondheidszorg } & 27 & 35 \\ \text { Gedrag en maatschappij } & 14 & 50 \\ & 24 & \mathbf{3 9} \\ \text { HBO } & & 35 \\ \text { Landbouw } & \mathbf{2 2} & 44 \\ \text { Onderwijs } & 24 & 35 \\ \text { Techniek } & 20 & 39 \\ \text { Economie } & 25 & 31 \\ \text { Gezondheidszorg } & 21 & 45 \\ \text { Gedrag en maatschappij } & 34 & \mathbf{3 6} \\ \text { Totaal } & 17 & \end{array}$

Bron: ROA (SIS)

\section{Toelichting}

Vraag in de enquête:

De examens/opdrachten waren over het algemeen zeer pittig ( 1 'helemaal mee oneens' tot 5 'helemaal mee eens'). Vermeld is het percentage van antwoordcategorie 4 en 5 (helemaal mee eens) en 1 en 2 (helemaal mee oneens). 
Tabel A4.5

Oordeel van gediplomeerde schoolverlaters: toetsen op inzicht Opleidingssector

Naar leerweg

Theoretisch

Gemengd

Kaderberoepsgericht

Basisberoepsgericht

$\begin{array}{ll} & \mathbf{2 1} \\ 36 & 22 \\ 51 & 22 \\ 41 & 20 \\ 42 & 21 \\ & 20\end{array}$

Naar sector
Landbouw
Techniek
Economie
Gezondheidszorg
MBO
BOL
BOL niveau 1
BOL niveau 2
Landbouw
Techniek
Economie
Gezondheidszorg
BOL niveau 3
Landbouw
Techniek
Economie
Gezondheidszorg
Gedrag en maatschappij

BOL niveau 4

Landbouw $\quad 34$

$37 \quad 24$

$\begin{array}{ll}36 & 30\end{array}$

$37-25$

$40 \quad 24$

$33 \quad 24$

Techniek

Economie

Gezondheidszorg

Gedrag en maatschappij

$35 \quad 30$

$33 \quad 32$

$39 \quad 28$

$40-30$

$34 \quad 34$

BBL

BBL niveau 1

BBL niveau 2

$\begin{array}{ll}\mathbf{4 3} & \mathbf{1 7} \\ 41 & 13 \\ 44 & 17 \\ 34 & 22 \\ 53 & 12\end{array}$


Tabel A4.5

Oordeel van gediplomeerde schoolverlaters: toetsen op inzicht

$\begin{array}{lrr}\text { Opleidingssector } & \text { (helemaal) mee eens } & \text { (helemaal) mee oneens } \\ \% & \%\end{array}$

BBL niveau 3

40

Landbouw

Techniek

40

Economie

Gezondheidszorg

Gedrag en maatschappij

20

BBL niveau 4

39

Landbouw

Techniek

Economie

Gezondheidszorg

Gedrag en maatschappij

$\begin{array}{ll}\mathbf{3 7} & \mathbf{2 8} \\ 52 & 35 \\ 44 & 21 \\ 31 & 37 \\ 34 & 26 \\ 37 & 25\end{array}$

HBO

Landbouw

$33 \quad 29$

Onderwijs

Techniek

Economie

Gezondheidszorg

Gedrag en maatschappij

$\begin{array}{ll}40 & 24 \\ 28 & 34 \\ 36 & 28 \\ 32 & 29 \\ 35 & 32 \\ 36 & 27\end{array}$

Totaal

40

Bron: ROA (SIS)

\section{Toelichting}

Vraag in de enquête:

In de opleiding werd voldoende getoetst op inzicht ( 1 helemaal mee oneens' tot 5 'helemaal mee eens'). Vermeld is het percentage van antwoordcategorie 4 en 5 (helemaal mee eens) en 1 en 2 (helemaal mee oneens). 
Tabel A5.1

Doorstroom van schoolverlaters naar vervolgonderwijs

$\begin{array}{lr}\text { Opleidingssector } & \text { verder leren } \\ \%\end{array}$

$\begin{array}{lr}\text { HAVO/VWO } & 89\end{array}$

$\begin{array}{lr}\text { HAVO } & 89\end{array}$

$\begin{array}{lr}\text { VWO } & 90\end{array}$

VMBO

Naarleerweg

Theoretisch

Gemengd

Kaderberoepsgericht

Basisberoepsgericht

$\begin{array}{ll}\text { Naar sector } & \\ \text { Landbouw } & 95 \\ \text { Techniek } & 92 \\ \text { Economie } & 93 \\ \text { Gezondheidszorg } & 94\end{array}$

MBO

BOL

B0L niveau 1

BOL niveau 2

59

Landbouw

Techniek

62

Economie

Gezondheidszorg

B0L niveau 3

Techniek

Economie

Gezondheidszorg

Gedrag en maatschappij

matschappij

BOL niveau 4

Landbouw

Techniek

Economie $\quad 62$

Gezondheidszorg 46

Gedrag en maatschappij

BBL

BBL niveau 1

BBL niveau 2

Techniek

Economie

Gezondheidszorg

BBL niveau 3

Techniek 
Tabel A5.1

Doorstroom van schoolverlaters naar vervolgonderwijs

\begin{tabular}{lr} 
Opleidingssector & verderleren \\
Gezondheidszorg & $\%$ \\
Gedrag en maatschappij & 12 \\
\hline
\end{tabular}

$\begin{array}{ll}\text { BBL niveau } 4 & 18\end{array}$

Landbouw 26

\begin{tabular}{ll} 
Techniek & 25 \\
\hline
\end{tabular}

Economie $\quad 19$

Gezondheidszorg

Gedrag en maatschappij 12

HBO

Landbouw

Onderwijs

Techniek

Economie

Gezondheidszorg

Gedrag en maatschappij

Taal en cultuur

Wo

Landbouw

Techniek

Economie

Gezondheidszorg

Gedrag en maatschappij

Taal en cultuur

Recht en openbare orde

Natuurwetenschappen

Totaal

Bron: ROA (SIS); VSNU/IVA, 2009 
Tabel A5.2

Type vervolgonderwijs

\begin{tabular}{|c|c|c|c|c|c|c|c|c|c|}
\hline Opleidingssector & HAVO & VW0 & VMBO & $\begin{array}{r}\text { BOL } \\
\text { niv. } 1 / 2 \\
\%\end{array}$ & $\begin{array}{r}\text { BOL } \\
\text { niv. } 3 / 4 \\
\%\end{array}$ & $\begin{array}{r}\text { BBL } \\
\text { niv. } 1 / 2 \\
\%\end{array}$ & $\begin{array}{r}\text { BBL } \\
\text { niv. } 3 / 4 \\
\%\end{array}$ & $\mathrm{HBO}$ & $\begin{array}{r}\text { post } \\
\text { HBO } \\
\%\end{array}$ \\
\hline HAVO/VWO & 0 & 0 & 0 & 1 & 2 & 0 & 0 & 53 & 0 \\
\hline HAVO & 0 & 0 & 0 & 1 & 3 & 0 & 1 & 83 & 0 \\
\hline VW0 & 0 & 0 & 0 & 0 & 0 & 0 & 0 & 13 & 0 \\
\hline $\begin{array}{l}\text { VMBO } \\
\text { Naar leerweg }\end{array}$ & 6 & 0 & 0 & 17 & 58 & 9 & 5 & 0 & 0 \\
\hline Theoretisch & 13 & 0 & 0 & 4 & 73 & 2 & 5 & 0 & 0 \\
\hline Gemengd & 2 & 0 & 0 & 5 & 81 & 6 & 4 & 0 & 0 \\
\hline Kaderberoepsgericht & 0 & 0 & 0 & 9 & 70 & 8 & 8 & 0 & 0 \\
\hline Basisberoepsgericht & 0 & 0 & 0 & 51 & 12 & 23 & 4 & 0 & 0 \\
\hline
\end{tabular}

\begin{tabular}{|c|c|c|c|c|c|c|c|c|c|}
\hline \multirow{5}{*}{$\begin{array}{l}\text { Naar sector } \\
\text { Landbouw } \\
\text { Techniek } \\
\text { Economie } \\
\text { Gezondheidszorg }\end{array}$} & \multirow[b]{2}{*}{1} & \multirow[b]{2}{*}{0} & \multirow[b]{2}{*}{0} & \multirow[b]{2}{*}{31} & \multirow[b]{2}{*}{44} & \multirow[b]{2}{*}{11} & \multirow[b]{2}{*}{7} & \multirow[b]{2}{*}{0} & \multirow[b]{2}{*}{0} \\
\hline & & & & & & & & & \\
\hline & 0 & 0 & 0 & 19 & 35 & 31 & 7 & 0 & 0 \\
\hline & 1 & 0 & 0 & 25 & 54 & 9 & 5 & 0 & 0 \\
\hline & 0 & 0 & 0 & 32 & 50 & 7 & 5 & 0 & 0 \\
\hline
\end{tabular}

\begin{tabular}{|c|c|c|c|c|c|c|c|c|c|c|}
\hline MBO & 0 & 0 & 0 & 2 & 11 & 2 & 9 & 18 & 0 & 0 \\
\hline BOL & 0 & 0 & 0 & 3 & 16 & 1 & 5 & 27 & 0 & 0 \\
\hline BOL niveau 1 & 0 & 0 & 0 & 31 & 7 & 8 & 2 & 2 & 0 & 0 \\
\hline BOL niveau 2 & 0 & 0 & 0 & 3 & 37 & 3 & 14 & 1 & 0 & 0 \\
\hline Landbouw & 0 & 0 & 0 & 6 & 32 & 2 & 12 & 0 & 0 & 0 \\
\hline Techniek & 0 & 0 & 0 & 3 & 34 & 4 & 19 & 1 & 0 & 0 \\
\hline Economie & 0 & 0 & 0 & 4 & 31 & 4 & 11 & 2 & 0 & 0 \\
\hline Gezondheidszorg & 0 & 0 & 0 & 2 & 47 & 1 & 15 & 0 & 0 & 0 \\
\hline
\end{tabular}

$\begin{array}{lrllllllrll}\text { BOL niveau 3 } & \mathbf{0} & \mathbf{0} & \mathbf{0} & \mathbf{0} & \mathbf{2 4} & \mathbf{1} & \mathbf{7} & \mathbf{1 0} & \mathbf{0} & \mathbf{0} \\ \text { Landbouw } & 0 & 0 & 0 & 0 & 24 & 4 & 10 & 2 & 0 & 0 \\ \text { Techniek } & 0 & 0 & 0 & 0 & 17 & 1 & 10 & 1 & 0 & 0 \\ \text { Economie } & 1 & 0 & 0 & 1 & 26 & 1 & 7 & 19 & 0 & 0 \\ \text { Gezondheidszorg } & 0 & 0 & 0 & 0 & 25 & 0 & 7 & 2 & 0 & 0 \\ \text { Gedrag en maatschappij } & 0 & 0 & 0 & 0 & 22 & 0 & 6 & 10 & 0 & 0\end{array}$

$\begin{array}{lllllllllll}\text { BOL niveau 4 } & \mathbf{0} & \mathbf{0} & \mathbf{0} & \mathbf{0} & \mathbf{4} & \mathbf{0} & \mathbf{1} & \mathbf{5 0} & \mathbf{0} & \mathbf{0} \\ \text { Landbouw } & 0 & 0 & 0 & 0 & 7 & 0 & 0 & 38 & 0 & 1 \\ \text { Techniek } & 0 & 0 & 0 & 0 & 4 & 0 & 1 & 48 & 0 & 0 \\ \text { Economie } & 0 & 0 & 0 & 0 & 4 & 0 & 1 & 57 & 0 & 0 \\ \text { Gezondheidszorg } & 0 & 0 & 0 & 0 & 6 & 0 & 3 & 36 & 0 & 0 \\ \text { Gedrag en maatschappij } & 0 & 0 & 0 & 0 & 2 & 0 & 1 & 54 & 0 & 0\end{array}$

$\begin{array}{lllllllllll}\text { BBL } & \mathbf{0} & \mathbf{0} & \mathbf{0} & \mathbf{0} & \mathbf{3} & \mathbf{2} & \mathbf{1 6} & \mathbf{3} & \mathbf{0} & \mathbf{0} \\ \text { BBL niveau 1 } & \mathbf{0} & \mathbf{0} & \mathbf{0} & \mathbf{1} & \mathbf{3} & \mathbf{1 6} & \mathbf{3} & \mathbf{0} & \mathbf{0} & \mathbf{0} \\ \text { BBL niveau 2 } & \mathbf{0} & \mathbf{0} & \mathbf{0} & \mathbf{0} & \mathbf{4} & \mathbf{2} & \mathbf{2 5} & \mathbf{1} & \mathbf{0} & \mathbf{0} \\ \text { Landbouw } & 0 & 0 & 0 & 0 & 1 & 4 & 14 & 0 & 0 & 0 \\ \text { Techniek } & 0 & 0 & 0 & 1 & 6 & 3 & 33 & 0 & 0 & 0 \\ \text { Economie } & 0 & 0 & 0 & 0 & 1 & 1 & 15 & 2 & 0 & 0 \\ \text { Gezondheidszorg } & 0 & 0 & 0 & 0 & 2 & 0 & 18 & 0 & 0 & 0\end{array}$


Tabel A5.2

Type vervolgonderwijs

$\begin{array}{rrrrrrrrrrrr} & \text { HAV0 } & \text { VWO } & \text { VMBO } & \text { BOL } & \text { BOL } & \text { BBL } & \text { BBL } & \text { HBO } & \text { post } & \text { W0 } \\ \text { Opleidingssector } & & & & \text { niv. } 1 / 2 & \text { niv. } 3 / 4 & \text { niv. } 1 / 2 & \text { niv. } 3 / 4 & & \text { HBO } & \\ & \% & \% & \% & \% & \% & \% & \% & \% & \% & \%\end{array}$

$\begin{array}{llllllrrrrr}\text { BBL niveau 3 } & \mathbf{0} & \mathbf{0} & \mathbf{0} & \mathbf{0} & \mathbf{3} & \mathbf{0} & \mathbf{1 4} & \mathbf{3} & \mathbf{0} & \mathbf{0} \\ \text { Landbouw } & 0 & 0 & 0 & 0 & 0 & 0 & 16 & 0 & 0 & 0 \\ \text { Techniek } & 0 & 0 & 0 & 0 & 5 & 1 & 18 & 3 & 0 & 0 \\ \text { Economie } & 0 & 0 & 0 & 0 & 4 & 0 & 15 & 6 & 0 & 0 \\ \text { Gezondheidszorg } & 0 & 0 & 0 & 0 & 2 & 0 & 8 & 0 & 0 & 0 \\ \text { Gedrag en maatschappij } & 0 & 0 & 0 & 0 & 0 & 0 & 7 & 10 & 0 & 0\end{array}$

\begin{tabular}{|c|c|c|c|c|c|c|c|c|c|}
\hline BBL niveau 4 & 0 & 0 & 0 & 0 & 2 & 0 & 4 & 11 & 0 \\
\hline Landbouw & 0 & 0 & 0 & 0 & 0 & 0 & 9 & 17 & 0 \\
\hline Techniek & 0 & 0 & 0 & 0 & 8 & 0 & 5 & 10 & 0 \\
\hline Economie & 0 & 0 & 0 & 0 & 0 & 0 & 4 & 15 & 0 \\
\hline Gezondheidszorg & 0 & 0 & 0 & 0 & 1 & 0 & 4 & 8 & 0 \\
\hline Gedrag en maatschappij & 0 & 0 & 0 & 0 & 0 & 0 & 0 & 10 & 0 \\
\hline
\end{tabular}

$\begin{array}{llllllllrrr}\text { HBO } & \mathbf{0} & \mathbf{0} & \mathbf{0} & \mathbf{0} & \mathbf{0} & \mathbf{0} & \mathbf{0} & \mathbf{7} & \mathbf{0} & \mathbf{2 1} \\ \text { Landbouw } & 0 & 0 & 0 & 0 & 0 & 0 & 0 & 5 & 0 & 15 \\ \text { Onderwijs } & 0 & 0 & 0 & 0 & 0 & 0 & 0 & 19 & 0 & 11 \\ \text { Techniek } & 0 & 0 & 0 & 0 & 0 & 0 & 0 & 4 & 0 & 25 \\ \text { Economie } & 0 & 0 & 0 & 0 & 0 & 0 & 0 & 5 & 0 & 29 \\ \text { Gezondheidszorg } & 0 & 0 & 0 & 0 & 0 & 0 & 0 & 9 & 0 & 14 \\ \text { Gedrag en maatschappij } & 0 & 0 & 0 & 0 & 0 & 0 & 0 & 6 & 0 & 18 \\ \text { Taal en cultuur } & 0 & 0 & 0 & 0 & 0 & 0 & 0 & 13 & 1 & 7 \\ \text { Totaal } & & & & & & & & \mathbf{3} & \mathbf{1 9} & \mathbf{1 0}\end{array}$

Bron: ROA (SIS) 
Tabel A5.3

Belangrijkste opleidingen van schoolverlaters die een vervolgopleiding zijn gaan volgen

HAVO

HBO B Opleiding leraar basisonderwijs

HBO B Opleiding tot Verpleegkundige

VWO

WO B Geneeskunde

WO B Psychologie

VMBO theoretische leerweg

HAVO

VMBO landbouw

BOL ZB Sociaal-pedagogisch werk

VMBO techniek

BOL MKF Elektrotechnische installatietechniek

VMBO economie

BOL BB Kok

\section{VMBO gezondheidszorg}

BOL BB Helpende zorg

BOL ZB Sociaal-pedagogisch werk

BOL ZB Verzorgende

BOL MKF Sociaal-pedagogisch werk

BOL BB Kapper

BOL MKF Onderwijsassistent

BOL niveau 1

BOL BB Helpende zorg

BOL niveau 2 landbouw

BOL ZB Dierverzorging

BOL ZB Sociaal-pedagogisch werk

BBL ZB Vakbekw, Hovenier

BOL niveau 2 techniek

BBL ZB Eerste autotechnicus

BOL niveau 2 economie

BBL ZB Zelfstandig werkend gastheer/-vrouw

BOL niveau 2 gezondheidszorg

BOL ZB Sociaal-pedagogisch werk

$B O L$ ZB Verzorgende

$B B L$ ZB Verzorgende

BBL ZB Sociaal-pedagogisch werk

BOL MKF Sociaal-pedagogisch werk

BOL niveau 3 landbouw

BOL KF Dierverzorging

BOL KF Dierenassistent paraveterinair

BOL niveau 3 economie

BOL Specialist ICT-beheerder

HBO B Bedrijfseconomie

BOL niveau 3 gezondheidszorg

BOL MKF Verpleegkundige

BBL MKF Verpleegkundige 
Tabel A5.3

Belangrijkste opleidingen van schoolverlaters die een vervolgopleiding zijn gaan volgen

BOL niveau 3 gedrag en maatschappij

BOL MKF Sociaal-pedagogisch werk

BOL MKF Onderwijsassistent

BBL MKF Sociaal-pedagogisch werk

HBO B Opleiding leraar basisonderwijs

\section{BOL niveau 4 landbouw}

BOL KF Dierenassistent paraveterinair 8

HBO B Diermanagement

$\mathrm{HBO}$ B Dier- en veehouderij

HBO B Bos- en natuurbeheer

\section{BOL niveau 4 techniek}

$\mathrm{HBO} B$ Communicatie

HBO B Graphic Design

BOL niveau 4 economie

$\mathrm{HBO}$ B Bedrijfseconomie

BOL niveau 4 gezondheidszorg

$\mathrm{HBO} B$ Opleiding tot Verpleegkundige

HBO B Opl. tot Fysiotherapeut

BOL niveau 4 gedrag en maatschappij

HBO B Opleiding leraar basisonderwijs

HBO B Pedagogiek

$H B O B$ Sociaal Pedagogische Hulpverlening

HBO B Maatschappelijk Werk en Dienstverlening

HBO landbouw

W0 M Animal Sciences and Aquaculture

WO M Food Technology

WO M Management, Economics and Consumer Studies

\section{HBO onderwijs}

HBO M Spec. Educational Needs: Leraar Speciaal Onderwijs

WO Pre-Master opleiding

WO B Pedagogische Wetenschappen

HBO Master Onderwijs

HBO techniek

WO Pre-Master opleiding

HBO economie

WO Pre-Master opleiding

HBO gezondheidszorg

WO Pre-Master opleiding

HBO Master Gezondheidszorg

WO B Psychologie

HBO gedrag en maatschappij

WO Pre-Master opleiding

WO B Psychologie

WO B Pedagogische Wetenschappen

HBO B Opleiding leraar basisonderwijs 


\section{Statistische Bijlage}

Tabel A5.3

Belangrijkste opleidingen van schoolverlaters die een vervolgopleiding zijn gaan volgen

HBO taal en cultuur

HBO M Muziek

HBO Master Taal en Cultuur

Bron: ROA (SIS)

Toelichting

In de tabel zijn alleen die opleidingen opgenomen die door ten minste $5 \%$ van de schoolverlaters worden gevolgd. 
Tabel A5.4

Doorstroom van schoolverlaters naar kenniscentrum beroepsonderwijs bedrijfsleven

$\begin{array}{lr}\text { HAVO } & 29 \\ \text { OVDB } & 10 \\ \text { ECABO } & 10 \\ \text { SVH } & 8 \\ \text { LOBAS } & 8 \\ \text { GOC } & 8 \\ \text { SVS } & 6 \\ \text { SVB } & 6 \\ \text { SOM } & 6 \\ \text { VaPro } & 6 \\ \text { VWO } & 50\end{array}$

VMBO theoretische leerweg

OVDB

ECABO

SVH

KOC

29

VMBO landbouw

LOBAS

OVDB

SVH

ECABO

KOC

SOM

\section{VMBO techniek}

SOM

SVB

INNOVAM

GOC

ECABO

\section{VMBO economie}

SVH

ECABO

OVDB

Handel/L-OVD

SOM

VMBO gezondheidszorg

OVDB

KOC

ECABO

BOL niveau 1

OVDB

Handel/L-OVD

6

SOM

SVH

INNOVAM

GOC

LOBAS 
Tabel A5.4

Doorstroom van schoolverlaters naar kenniscentrum beroepsonderwijs bedrijfsleven

BOL niveau 2 techniek

SOM

INNOVAM

VOC/BETEX

$\mathrm{GOC}$

ECABO

BOL niveau 2 economie

ECABO

SVH

Handel/L-OVD

OVDB

BOL niveau 2 gezondheidszorg

OVDB

ECABO

BOL niveau 3 landbouw

LOBAS

OVDB

SOM

SVB

VTL

BOL niveau 3 economie

ECABO

Handel/L-OVD

OVDB

SOM

GOC

$B O L$ niveau 3 gezondheidszorg

OVDB

KOC

BOL niveau 3 gedrag en maatschappij

OVDB

BOL niveau 4 landbouw

LOBAS

\section{BOL niveau 4 techniek}

GOC

SVGB

VOC/BETEX

ECABO

SOM

KOC

\section{BOL niveau 4 economie}

OVDB

Handel/L-OVD

SVH

KOC

LOBAS

VaPro

ECABO 
Tabel A5.4

Doorstroom van schoolverlaters naar kenniscentrum beroepsonderwijs bedrijfsleven

BOL niveau 4 gezondheidszorg

OVDB

VOC/BETEX

$\mathrm{ECABO}$

BOL niveau 4 gedrag en maatschappij

OVDB

LOBAS

Bron: ROA (SIS)

Toelichting

In de tabel zijn alleen die kenniscentra opgenomen die door ten minste $5 \%$ van de schoolverlaters worden gevolgd. 
Tabel A5.5

Oordeel van schoolverlaters over de aansluiting van de afgesloten opleiding met de vervolgopleiding

\begin{tabular}{|c|c|c|c|c|}
\hline Opleidingssector & $\begin{array}{r}\text { goed } \\
\%\end{array}$ & $\begin{array}{r}\text { redelijk } \\
\%\end{array}$ & $\begin{array}{r}\text { matig } \\
\%\end{array}$ & $\begin{array}{r}\text { slecht } \\
\%\end{array}$ \\
\hline HAVO/VWO & 34 & 42 & 19 & 6 \\
\hline HAVO & 32 & 41 & 20 & 7 \\
\hline vwo & 36 & 43 & 17 & 5 \\
\hline VMBO & 35 & 35 & 20 & 10 \\
\hline Naarleerweg & & & & \\
\hline Theoretisch & 32 & 36 & 20 & 12 \\
\hline Gemengd & 34 & 36 & 18 & 12 \\
\hline Kaderberoepsgericht & 31 & 41 & 22 & 6 \\
\hline Basisberoepsgericht & 48 & 26 & 15 & 11 \\
\hline Naar sector & & & & \\
\hline Landbouw & 32 & 34 & 24 & 9 \\
\hline Techniek & 42 & 30 & 15 & 13 \\
\hline Economie & 41 & 34 & 18 & 7 \\
\hline Gezondheidszorg & 35 & 37 & 19 & 8 \\
\hline MBO & 32 & 38 & 20 & 10 \\
\hline BOL & 31 & 39 & 20 & 10 \\
\hline BOL niveau 1 & 41 & 40 & 16 & 3 \\
\hline BOL niveau 2 & 46 & 34 & 14 & 6 \\
\hline Landbouw & 57 & 20 & 14 & 9 \\
\hline Techniek & 44 & 27 & 15 & 14 \\
\hline Economie & 48 & 37 & 11 & 4 \\
\hline Gezondheidszorg & 42 & 38 & 16 & 4 \\
\hline BOL niveau 3 & 37 & 43 & 15 & 6 \\
\hline Landbouw & 42 & 43 & 0 & 15 \\
\hline Economie & 33 & 42 & 18 & 7 \\
\hline Gezondheidszorg & 48 & 35 & 15 & 2 \\
\hline Gedrag en maatschappij & 34 & 50 & 13 & 3 \\
\hline BOL niveau 4 & 24 & 39 & 24 & 13 \\
\hline Landbouw & 32 & 38 & 23 & 7 \\
\hline Techniek & 25 & 35 & 26 & 15 \\
\hline Economie & 23 & 40 & 24 & 12 \\
\hline Gezondheidszorg & 21 & 44 & 24 & 11 \\
\hline Gedrag en maatschappij & 23 & 39 & 24 & 15 \\
\hline BBL & 41 & 35 & 10 & 14 \\
\hline BBL niveau 3 & 36 & 48 & 8 & 8 \\
\hline BBL niveau 4 & 31 & 35 & 14 & 21 \\
\hline Totaal & 36 & 38 & 18 & 9 \\
\hline
\end{tabular}

Toelichting

Vraag in de enquête: Hoe is de aansluiting tussen de gevolgde [...] opleiding en deze vervolgopleiding? 
Tabel A6.1

Uitvallers en studiewisselaars

$\begin{array}{lrr}\text { Opleidingssector } & \begin{array}{r}\text { vervolgopleiding voortijdig } \\ \text { verlaten } \\ \text { studiewisselaar }\end{array} & \% \\ \text { HAVO/VWO } & \% & \mathbf{1 8} \\ \text { HAVO } & \mathbf{2 1} & 18 \\ \text { VWO } & 22 & 18 \\ \text { VMBO } & 20 & \mathbf{8} \\ \text { Naarleerweg } & & 9 \\ \text { Theoretisch } & \mathbf{1 1} & 11 \\ \text { Gemengd } & & 9 \\ \text { Kaderberoepsgericht } & 10 & 5 \\ \text { Basisberoepsgericht } & 11 & 12 \\ \end{array}$

\begin{tabular}{|c|c|c|}
\hline \\
\hline \multicolumn{3}{|l|}{ Landbouw } \\
\hline Techniek & 10 & 7 \\
\hline Economie & 13 & 10 \\
\hline Gezondheidszorg & 13 & 8 \\
\hline MBO & 10 & 3 \\
\hline BOL & 11 & 4 \\
\hline BOL niveau 1 & 6 & 2 \\
\hline BOL niveau 2 & 9 & 3 \\
\hline Landbouw & 2 & 1 \\
\hline Techniek & 7 & 1 \\
\hline Economie & 6 & 3 \\
\hline Gezondheidszorg & 14 & 5 \\
\hline BOL niveau 3 & 9 & 1 \\
\hline Landbouw & 8 & 0 \\
\hline Economie & 5 & 1 \\
\hline Gezondheidszorg & 8 & 0 \\
\hline Gedrag en maatschappij & 10 & 1 \\
\hline BOL niveau 4 & 14 & 5 \\
\hline Landbouw & 12 & 5 \\
\hline Techniek & 14 & 5 \\
\hline Economie & 13 & 6 \\
\hline Gezondheidszorg & 13 & 5 \\
\hline Gedrag en maatschappij & 16 & 4 \\
\hline BBL & 8 & 2 \\
\hline BBL niveau 1 & 8 & 0 \\
\hline BBL niveau 2 & 4 & 2 \\
\hline BBL niveau 3 & 8 & 0 \\
\hline BBL niveau 4 & 23 & 5 \\
\hline
\end{tabular}


Statistische Bijlage

Tabel A6.1

Uitvallers en studiewisselaars

Opleidingssector

vervolgopleiding voortijdig

verlaten

studiewisselaar

$\%$

HBO

Landbouw

Onderwijs

Techniek

Economie

Gezondheidszorg

Gedrag en maatschappij

Taal en cultuur

$\begin{array}{rr}7 & 0 \\ 2 & 0 \\ 7 & 0 \\ 9 & 1 \\ 6 & 0 \\ 5 & 0 \\ 11 & 0 \\ 8 & 2\end{array}$

Totaal

13

9

Bron: ROA (SIS) 
Tabel A7.1

Opleiding achteraf opnieuw kiezen: doorstroom naar vervolgonderwijs

$\begin{array}{lcr}\text { Opleidingssector } & \begin{array}{r}\text { zelfde } \\ \text { opleiding } \\ \%\end{array} & \begin{array}{r}\text { andere } \\ \text { opleiding } \\ \%\end{array} \\ \text { VMBO } & \mathbf{8 3} & \mathbf{1 7} \\ \text { Naar leerweg } & & 15 \\ \text { Theoretisch } & 85 & 10 \\ \text { Gemengd } & 90 & 15 \\ \text { Kaderberoepsgericht } & 85 & 25 \\ \text { Basisberoepsgericht } & 75 & 25\end{array}$

\begin{tabular}{|c|c|c|}
\hline \multicolumn{3}{|l|}{ Naar sector } \\
\hline Landbouw & 83 & 17 \\
\hline Techniek & 83 & 17 \\
\hline Economie & 74 & 26 \\
\hline Gezondheidszorg & 83 & 17 \\
\hline MBO & 79 & 21 \\
\hline BOL & 77 & 23 \\
\hline BoL niveau 1 & 73 & 27 \\
\hline BOL niveau 2 & 76 & 24 \\
\hline Landbouw & 74 & 26 \\
\hline Techniek & 81 & 19 \\
\hline Economie & 74 & 26 \\
\hline Gezondheidszorg & 75 & 25 \\
\hline
\end{tabular}

$\begin{array}{ll}\text { Economie } & 72 \\ & 72\end{array}$

Gezondheidszorg $\quad 75$

Gedrag en maatschappij $\quad 80$

\begin{tabular}{lcc} 
BOL niveau 4 & $\mathbf{7 8}$ & $\mathbf{2 2}$ \\
Landbouw & 84 & 16 \\
Techniek & 76 & 24 \\
Economie & 74 & 26 \\
Gezondheidszorg & 82 & 18 \\
Gedrag en maatschappij & 82 & 18 \\
BBL & $\mathbf{8 8}$ & $\mathbf{1 2}$ \\
BBL niveau 1 & & $\mathbf{0}$ \\
BBL niveau 2 & $\mathbf{1 0 0}$ & $\mathbf{1 1}$ \\
BBL niveau 3 & & \\
& $\mathbf{8 9}$ & 14 \\
BBL niveau 4 & & \\
HB0 & 86 & $\mathbf{1 8}$ \\
Landbouw & & $\mathbf{2 3}$ \\
Onderwijs & $\mathbf{8 2}$ & 18 \\
Techniek & & 12 \\
Economie & $\mathbf{7 7}$ & 19 \\
Gezondheidszorg & 82 & 29 \\
Gedrag en maatschappij & 88 & 19 \\
Taal en cultuur & 81 & 29 \\
\hline
\end{tabular}


Statistische Bijlage

Tabel A7.1

Opleiding achteraf opnieuw kiezen: doorstroom naar vervolgonderwijs

$\begin{array}{rrr}\text { Opleidingssector } & \text { zelfde } & \text { andere } \\ & \text { opleiding } & \% \\ & \% & \%\end{array}$

wo

$87 \quad 13$

Landbouw

85

Techniek

Economie

Gezondheidszorg

Gedrag en maatschappij

Taal en cultuur

Recht en openbare orde

Natuurwetenschappen

91

Totaal

81

15

10

18

9

18

16

11

Bron: ROA (SIS);VSNU/IVA, 2009 
Tabel A8.1

Belangrijkste bedrijfsgroepen waarin schoolverlaters werkzaam zijn

HAVO

Overheidsdiensten

Supermarkten, warenhuizen en dergelijke winkels met een algemeen assortiment

Restaurants, cafetaria's e.d.

Ziekenhuizen

VW0

Supermarkten, warenhuizen en dergelijke winkels met een algemeen assortiment

Winkels in overige artikelen

Restaurants, cafetaria's e.d.

Kantines en catering

Geldscheppende financiële instellingen

Accountancy, belastingadvisering en administratie

Overheidsdiensten

\section{VMBO theoretische leerweg}

Overheidsdiensten

Supermarkten, warenhuizen en dergelijke winkels met een algemeen assortiment

Restaurants, cafetaria's e.d.

Wellness en overige dienstverlening; uitvaartbranche

Winkels in overige artikelen

VMBO landbouw

Winkels in overige artikelen

Wellness en overige dienstverlening; uitvaartbranche

Restaurants, cafetaria's e.d.

Supermarkten, warenhuizen en dergelijke winkels met een algemeen assortiment

Overheidsdiensten

\section{VMBO techniek}

Bouwinstallatie

Overheidsdiensten

Algemene burgerlijke en utiliteitsbouw

Dakbouw en overige gespecialiseerde werkzaamheden in de bouw

Gespecialiseerde reparatie van auto's

Supermarkten, warenhuizen en dergelijke winkels met een algemeen assortiment

\section{VMBO economie}

Supermarkten, warenhuizen en dergelijke winkels met een algemeen assortiment

Winkels in overige artikelen

Restaurants, cafetaria's e.d.

Callcenters

\section{VMBO gezondheidszorg}

Wellness en overige dienstverlening; uitvaartbranche

Supermarkten, warenhuizen en dergelijke winkels met een algemeen assortiment 15

Winkels in overige artikelen

Overheidsdiensten

Restaurants, cafetaria's e.d.

\section{BOL niveau 1}

Supermarkten, warenhuizen en dergelijke winkels met een algemeen assortiment 21

Hotels e.d.

Reiniging

Overheidsdiensten

BOL niveau 2 landbouw

Dienstverlening voor de landbouw; behandeling van gewassen en zaden na de oogst 12

Winkels in overige artikelen 
Tabel A8.1

Belangrijkste bedrijfsgroepen waarin schoolverlaters werkzaam zijn

\section{BOL niveau 2 techniek}

Handel in auto's en aanhangers, eventueel gecombineerd met reparatie 12

Supermarkten, warenhuizen en dergelijke winkels met een algemeen assortiment 12

\begin{tabular}{lr} 
Bouwinstallatie & 8 \\
\hline
\end{tabular}

Bouw van overige civieltechnische werken $\quad 6$

$\begin{array}{lr}\text { BOL niveau } 2 \text { economie } & 21 \\ \text { Overheidsdiensten } & 15 \\ \text { Restaurants, cafetaria's e.d. } & 9 \\ \text { Particuliere beveiliging } & 8 \\ \text { Hotels e.d. } & 6 \\ \text { Winkels in overige artikelen } & 6\end{array}$

BOL niveau 2 gezondheidszorg

$\begin{array}{ll}\text { Verpleeghuizen } & 27\end{array}$

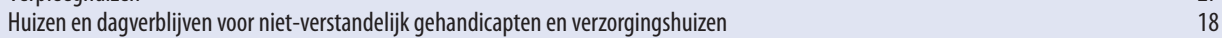

Maatschappelijke dienstverlening zonder overnachting niet specifiek gericht op ouderen en 16

Wellness en overige dienstverlening; uitvaartbranche $\quad 8$

Maatschappelijke dienstverlening zonder overnachting gericht op ouderen en gehandicapten $\quad 6$

\section{BOL niveau 3 landbouw}

Winkels in overige artikelen

Veterinaire dienstverlening

Fokken en houden van dieren

Slopen van bouwwerken, grondverzet en proefboren

Landschapsverzorging

BOL niveau 3 economie

Dienstverlenende activiteiten op het gebied van informatietechnologie 13

Winkels in overige artikelen

Overheidsdiensten

BOL niveau 3 gezondheidszorg

Wellness en overige dienstverlening; uitvaartbranche

Verpleeghuizen

Maatschappelijke dienstverlening zonder overnachting gericht op ouderen en gehandicapten

\begin{tabular}{ll} 
Ziekenhuizen & 12 \\
\hline
\end{tabular}

Huizen en dagverblijven voor niet-verstandelijk gehandicapten en verzorgingshuizen 12

Paramedische praktijken en overige gezondheidszorg zonder overnachting 5

Huizen en dagverblijven voor verstandelijk gehandicapten en psychiatrische cliënten 5

BOL niveau 3 gedrag en maatschappij

Maatschappelijke dienstverlening zonder overnachting niet specifiek gericht op ouderen en 61

Huizen en dagverblijven voor verstandelijk gehandicapten en psychiatrische cliënten 13

Huizen en dagverblijven voor niet-verstandelijk gehandicapten en verzorgingshuizen

\section{BOL niveau 4 landbouw}

Veterinaire dienstverlening

Winkels in overige artikelen

Landschapsverzorging

Fokken en houden van dieren

Supermarkten, warenhuizen en dergelijke winkels met een algemeen assortiment

Openbaar bestuur

\section{BOL niveau 4 techniek}

Winkels in overige artikelen

Reclamebureaus en handel in advertentieruimte en -tijd

Industrieel ontwerp en vormgeving 
Tabel A8.1

Belangrijkste bedrijfsgroepen waarin schoolverlaters werkzaam zijn

BOL niveau 4 economie

Winkels in overige artikelen

Hotels e.d.

Restaurants, cafetaria's e.d.

Accountancy, belastingadvisering en administratie

Supermarkten, warenhuizen en dergelijke winkels met een algemeen assortiment

BOL niveau 4 gezondheidszorg

Ziekenhuizen

Medische en tandheelkundige praktijken

Winkels in overige artikelen

BOL niveau 4 gedrag en maatschappij

Maatschappelijke dienstverlening zonder overnachting niet specifiek gericht op ouderen en 34

Huizen en dagverblijven voor verstandelijk gehandicapten en psychiatrische cliënten 23

Primair en speciaal onderwijs

BBL niveau 1

Vervaardiging van overige goederen

Groothandel in voedings- en genotmiddelen

Landschapsverzorging

BBL niveau 2 landbouw

Landschapsverzorging

Vervaardiging van overige goederen

Teelt van eenjarige gewassen

Winkels in overige artikelen

\section{BBL niveau 2 techniek}

Bouwinstallatie

Nationale post met universele dienstverplichting

Algemene burgerlijke en utiliteitsbouw

Afwerking van gebouwen

Handel in auto's en aanhangers, eventueel gecombineerd met reparatie

Goederenvervoer over de weg

BBL niveau 2 economie

Restaurants, cafetaria's e.d.

20

Winkels in overige artikelen

Overheidsdiensten

Particuliere beveiliging

\section{BBL niveau 2 gezondheidszorg}

Verpleeghuizen

Huizen en dagverblijven voor niet-verstandelijk gehandicapten en verzorgingshuizen

Verpleging, verzorging en begeleiding met overnachting

Wellness en overige dienstverlening; uitvaartbranche

Ziekenhuizen

Huizen en dagverblijven voor verstandelijk gehandicapten en psychiatrische cliënten

Maatschappelijke dienstverlening zonder overnachting niet specifiek gericht op ouderen en

\section{BBL niveau 3 landbouw}

Landschapsverzorging

Winkels in overige artikelen

Fokken en houden van dieren

Vervaardiging van overige goederen

Teelt van sierplanten 
Tabel A8.1

Belangrijkste bedrijfsgroepen waarin schoolverlaters werkzaam zijn

\section{BBL niveau 3 techniek}

Bouwinstallatie

Handel in auto's en aanhangers, eventueel gecombineerd met reparatie

BBL niveau 3 economie

Restaurants, cafetaria's e.d.

Supermarkten, warenhuizen en dergelijke winkels met een algemeen assortiment

Hotels e.d.

Winkels in overige artikelen

\section{BBL niveau 3 gezondheidszorg}

Verpleeghuizen

Huizen en dagverblijven voor niet-verstandelijk gehandicapten en verzorgingshuizen

Maatschappelijke dienstverlening zonder overnachting gericht op ouderen en gehandicapten

Verpleging, verzorging en begeleiding met overnachting

Wellness en overige dienstverlening; uitvaartbranche

Ziekenhuizen

Huizen en dagverblijven voor verstandelijk gehandicapten en psychiatrische cliënten

BBL niveau 3 gedrag en maatschappij

Maatschappelijke dienstverlening zonder overnachting niet specifiek gericht op ouderen en

Huizen en dagverblijven voor verstandelijk gehandicapten en psychiatrische cliënten

\section{BBL niveau 4 techniek}

Bouwinstallatie

Handel in auto's en aanhangers, eventueel gecombineerd met reparatie

Algemene burgerlijke en utiliteitsbouw

Vervaardiging van brood, banketbakkerswerk en deegwaren

Vervaardiging van farmaceutische producten (geen grondstoffen)

Winkels in overige artikelen

Overheidsdiensten

\section{BBL niveau 4 economie}

Winkels in overige artikelen $\quad 16$

Restaurants, cafetaria's e.d.

Openbaar bestuur

\section{BBL niveau 4 gezondheidszorg}

\section{Ziekenhuizen}

Huizen en dagverblijven voor verstandelijk gehandicapten en psychiatrische cliënten

Maatschappelijke dienstverlening zonder overnachting gericht op ouderen en gehandicapten

\section{BBL niveau 4 gedrag en maatschappij}

Huizen en dagverblijven voor verstandelijk gehandicapten en psychiatrische cliënten

Maatschappelijke dienstverlening zonder overnachting niet specifiek gericht op ouderen en

Primair en speciaal onderwijs

Jeugdzorg en maatschappelijke opvang met overnachting

Overheidsdiensten

Voortgezet onderwijs

Ziekenhuizen

Huizen en dagverblijven voor niet-verstandelijk gehandicapten en verzorgingshuizen

Maatschappelijke dienstverlening zonder overnachting gericht op ouderen en gehandicapten

\section{HBO landbouw}

Architecten, ingenieurs en technisch ontwerp en advies

Groothandel in landbouwproducten en levende dieren 
Tabel A8.1

Belangrijkste bedrijfsgroepen waarin schoolverlaters werkzaam zijn

HBO onderwijs

Primair en speciaal onderwijs $\quad 70$

Voortgezet onderwijs

HBO techniek

Architecten, ingenieurs en technisch ontwerp en advies 16

Dienstverlenende activiteiten op het gebied van informatietechnologie 14

HBO economie

Accountancy, belastingadvisering en administratie 8

Geldscheppende financiële instellingen 5

\section{HBO gezondheidszorg}

Paramedische praktijken en overige gezondheidszorg zonder overnachting 39

Ziekenhuizen

HBO gedrag en maatschappij

Maatschappelijke dienstverlening zonder overnachting niet specifiek gericht op ouderen en 22

Huizen en dagverblijven voor verstandelijk gehandicapten en psychiatrische cliënten 13

Jeugdzorg en maatschappelijke opvang met overnachting

Ziekenhuizen 9

Maatschappelijke dienstverlening zonder overnachting gericht op ouderen en gehandicapten 5

$\begin{array}{lr}\text { HBO taal en cultuur } & 26 \\ \text { Kunst } & 16 \\ \text { Industrieel ontwerp en vormgeving } & 7 \\ \text { Voortgezet onderwijs } & 7 \\ \text { Overig onderwijs } & 7\end{array}$

Bron: ROA (SIS)

Toelichting

De bedrijven waarin de schoolverlaters werkzaam zijn, zijn geclassificeerd volgens de Standaard Bedrijfs Indeling van het CBS. Op het hier gepresenteerde niveau van bedrijfsgroepen worden in total 211 categorieën onderscheiden.

In de tabel zijn alleen die bedrijfsgroepen weergegeven waarin ten minste $5 \%$ van de schoolverlaters werkzaam is. 
Tabel A8.2

Belangrijkste beroepsgroepen waarin schoolverlaters werkzaam zijn

HAVO

Elementaire beroepen

Aspirant politieagenten, soldaten en beveiligingshulpkrachten

Verkopers

Receptionisten en administratieve employés

Hulpkrachten horeca en verzorging

Commercieel employés

Winkeliers

Politieagenten, onderofficieren en beveiligingsemployés

vW0

Verkopers

Hulpkrachten horeca en verzorging

Elementaire beroepen

Receptionisten en administratieve employés

Boekhouders en secretaresses

Commercieel employés

Assistent accountants

\section{VMBO theoretische leerweg}

Verkopers

Elementaire beroepen

Hulpkrachten horeca en verzorging

Verzorgend personeel

Aspirant politieagenten, soldaten en beveiligingshulpkrachten

Receptionisten en administratieve employés

VMBO landbouw

Verkopers

Hulpkrachten horeca en verzorging

Verzorgend personeel

Elementaire beroepen

Agrarische arbeider

Monteurs

\section{VMBO techniek}

Bouwvakkers

Aspirant politieagenten, soldaten en beveiligingshulpkrachten 12

Elementaire beroepen

Aannemers en installateurs

Monteurs

Elektromonteurs

Metaalarbeiders

Monteurs en controleurs elektrotechnische producten

Chauffeurs

\section{VMBO economie}

Verkopers

Hulpkrachten horeca en verzorging

Elementaire beroepen

Receptionisten en administratieve employés

\section{VMBO gezondheidszorg}

Verkopers

Verzorgend personeel

Hulpkrachten horeca en verzorging

Elementaire beroepen

Aspirant politieagenten, soldaten en beveiligingshulpkrachten 
Tabel A8.2

Belangrijkste beroepsgroepen waarin schoolverlaters werkzaam zijn

\section{B0L niveau 1}

Elementaire beroepen

Hulpkrachten horeca en verzorging 17

Verkopers

Aspirant politieagenten, soldaten en beveiligingshulpkrachten 7

Monteurs

Elektromonteurs

\section{BOL niveau 2 landbouw}

Agrarische arbeider

Verkopers

Elementaire beroepen

Agrarische bedrijfshoofden

\section{BOL niveau 2 techniek}

Monteurs

Elementaire beroepen

Aannemers en installateurs

Elektromonteurs

Programmeurs

Chauffeurs

BOL niveau 2 economie

Aspirant politieagenten, soldaten en beveiligingshulpkrachten 22

Hulpkrachten horeca en verzorging 18

9

Receptionisten en administratieve employés 9

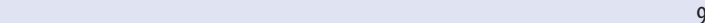

Politieagenten, onderofficieren en beveiligingsemployés 6

Verzorgend personeel

BOL niveau 2 gezondheidszorg

Verzorgend personeel

Elementaire beroepen

Hulpkrachten horeca en verzorging 14

\section{BOL niveau 3 landbouw}

Verkopers

Agrarische arbeider

Agrarische vakkrachten

Verzorgend personeel

BOL niveau 3 economie

Programmeurs

Boekhouders en secretaresses

Commercieel employés

Hulpkrachten horeca en verzorging

Receptionisten en administratieve employés

BOL niveau 3 gezondheidszorg

Verzorgend personeel

Hulpkrachten horeca en verzorging

Verplegenden en doktersassistenten

Ziekenverzorgenden

BOL niveau 3 gedrag en maatschappij

Verzorgend personeel

69

Hulpkrachten horeca en verzorging

Activiteitenbegeleiders en medewerkers arbeidsbemiddeling 
Tabel A8.2

Belangrijkste beroepsgroepen waarin schoolverlaters werkzaam zijn

BOL niveau 4 landbouw

Verplegenden en doktersassistenten

Agrarische arbeider

Agrarische bedrijfshoofden

Elementaire beroepen

\section{BOL niveau 4 techniek}

Grafisch ontwerpers

Aannemers en installateurs

Verkopers

Monteurs

Elektromonteurs

Commercieel employés

BOL niveau 4 economie

Receptionisten en administratieve employés 17

Boekhouders en secretaresses 16

Commercieel employés

Verkopers

Hulpkrachten horeca en verzorging 5

Programmeurs

Winkeliers

BOL niveau 4 gezondheidszorg

Verplegenden en doktersassistenten $\quad 52$

Verzorgend personeel

Apothekersassistenten en medisch laboranten

B0L niveau 4 gedrag en maatschappi

Verzorgend personeel

Activiteitenbegeleiders en medewerkers arbeidsbemiddeling

Hulpkrachten horeca en verzorging

BBL niveau 1

Elementaire beroepen

Agrarische arbeiders

Hulpkrachten horeca en verzorging

Bouwvakkers

BBL niveau 2 landbouw

Agrarische arbeider

Bouwvakkers

Weg- en waterbouwkundige vakkrachten

Monteurs

Agrarische vakkrachten

\section{BBL niveau 2 techniek}

Chauffeurs

Aannemers en installateurs

Bouwvakkers

Elementaire beroepen

Monteurs

Elektromonteurs 
Tabel A8.2

Belangrijkste beroepsgroepen waarin schoolverlaters werkzaam zijn

BBL niveau 2 economie

Verzorgend personeel

Aspirant politieagenten, soldaten en beveiligingshulpkrachten

Hulpkrachten horeca en verzorging

Winkeliers

Elementaire beroepen

Activiteitenbegeleiders en medewerkers arbeidsbemiddeling

B niveau 2 gezondheidszorg

Verzorgend personeel

BBL niveau 3 landbouw

Agrarische arbeider

Agrarische vakkrachten

Agrarische bedrijfshoofden

Bouwvakkers

Procestechnische beroepen (mid)

\section{BBL niveau 3 techniek}

Monteurs

Aannemers en installateurs

Bouwvakkers

Procestechnische beroepen (mid)

Elektromonteurs

Weg- en waterbouwkundige vakkrachten

\section{BBL niveau 3 economie}

Verzorgend personeel

Verkopers

Hulpkrachten horeca en verzorging

Winkeliers

Boekhouders en secretaresses

BBL niveau 3 gezondheidszorg

Verzorgend personeel

Hulpkrachten horeca en verzorging

Verpleeghulpen en leerling-verpleegkundigen

Ziekenverzorgenden

BBL niveau 3 gedrag en maatschappij

Verzorgend personeel

\section{BBL niveau 4 techniek}

Monteurs

Aannemers en installateurs

Elektromonteurs

Procestechnische beroepen (mid)

Productieplanners

Bouwvakkers

Laboranten

Elektronicamonteurs

Apothekersassistenten en medisch laboranten

BBL niveau 4 economie

Winkeliers

Verkopers

Receptionisten en administratieve employés 
Tabel A8.2

Belangrijkste beroepsgroepen waarin schoolverlaters werkzaam zijn

BBL niveau 4 gezondheidszorg

Verplegenden en doktersassistenten

Verzorgend personeel

Apothekersassistenten en medisch laboranten

BBL niveau 4 gedrag en maatschappij

Verzorgend personeel

Activiteitenbegeleiders en medewerkers arbeidsbemiddeling

Hulpkrachten horeca en verzorging

\section{HBO landbouw}

Milieuhygienisten en agrarisch vertegenwoordigers

Commercieel medewerkers

Agrarische arbeider

Organisatie-adviseurs

\section{HBO onderwijs}

Leraar basisonderwijs

Docenten sociale vakken (2e en 3e gr.)

\section{HBO techniek}

Architecten en bouwkundig projectleiders

Systeemanalisten

Werktuigbouwkundig ontwerpers en hoofden technische dienst

Weg- en waterbouwkundig ontwerpers en projectleiders

\section{HBO economie}

Commercieel medewerkers $\quad 22$

Assistent accountants

Organisatie-adviseurs 10

Commercieel employés

Receptionisten en administratieve employés 6

\section{HBO gezondheidszorg}

Therapeuten en verpleegkundigen

HBO gedrag en maatschappij

Sociaal-cultureel werkers

Verzorgend personeel

Hulpkrachten horeca en verzorging

Activiteitenbegeleiders en medewerkers arbeidsbemiddeling

\section{HBO taal en cultuur}

Kunstenaars

Docenten talen en expressie

Bron: ROA (SIS)

\section{Toelichting}

De beroepen waarin de schoolverlaters werkzaam zijn, zijn geclassificeerd volgens de Standaard Beroepenclassificatie 1992 van het CBS. Binnen de elementaire beroepen is hierbij door het ROA een nader onderscheid gemaakt. Bovendien zijn de namen van de beroepen verduidelijkt. Op het hier gepresenteerde niveau van beroepsgroepen worden in totaal 127 categorieën onderscheiden. In de tabel zijn alleen die beroepsgroepen weergegeven waarin ten minste $5 \%$ van de schoolverlaters werkzaam is. 
Tabel A8.3

Grootte van de organisatie waarin schoolverlaters werkzaam zijn

\begin{tabular}{|c|c|c|c|c|c|c|c|}
\hline Opleidingssector & $\begin{array}{r}1 \mathrm{t} / \mathrm{m} 9 \\
\text { pers. } \\
\%\end{array}$ & $\begin{array}{r}10 \mathrm{t} / \mathrm{m} 24 \\
\text { pers. } \\
\%\end{array}$ & $\begin{array}{r}25 \mathrm{t} / \mathrm{m} 49 \\
\text { pers. } \\
\%\end{array}$ & $\begin{array}{r}50 \mathrm{t} / \mathrm{m} 99 \\
\text { pers. } \\
\%\end{array}$ & $\begin{array}{r}100 \mathrm{t} / \mathrm{m} 249 \\
\text { pers. } \\
\%\end{array}$ & $\begin{array}{r}250 \mathrm{t} / \mathrm{m} 999 \\
\text { pers. } \\
\%\end{array}$ & $\begin{array}{r}\geq 1000 \\
\text { pers } \\
\%\end{array}$ \\
\hline HAVO/VWO & 8 & 10 & 7 & 5 & 4 & 10 & 56 \\
\hline HAVO & 6 & 11 & 9 & 3 & 1 & 11 & 59 \\
\hline VW0 & 11 & 9 & 4 & 7 & 9 & 7 & 52 \\
\hline $\begin{array}{l}\text { VMBO } \\
\text { Naar leerweg }\end{array}$ & 26 & 10 & 13 & 12 & 12 & 8 & 19 \\
\hline Theoretisch & 19 & 12 & 15 & 11 & 11 & 10 & 23 \\
\hline Gemengd & 21 & 1 & 10 & 11 & 14 & 9 & 35 \\
\hline Kaderberoepsgericht & 30 & 13 & 13 & 12 & 8 & 7 & 16 \\
\hline Basisberoepsgericht & 27 & 8 & 11 & 13 & 16 & 7 & 18 \\
\hline Naar sector & & & & & & & \\
\hline Landbouw & 26 & 16 & 6 & 19 & 12 & 6 & 15 \\
\hline Techniek & 23 & 12 & 14 & 16 & 12 & 8 & 15 \\
\hline Economie & 28 & 5 & 15 & 9 & 5 & 9 & 29 \\
\hline Gezondheidszorg & 39 & 7 & 10 & 8 & 18 & 4 & 14 \\
\hline MBO & 15 & 12 & 10 & 9 & 10 & 16 & 28 \\
\hline BOL & 17 & 13 & 9 & 7 & 10 & 15 & 29 \\
\hline B0L niveau 1 & 21 & 21 & 14 & 7 & 7 & 7 & 24 \\
\hline BOL niveau 2 & 23 & 14 & 8 & 4 & 9 & 10 & 32 \\
\hline Landbouw & 57 & 15 & 6 & & & 13 & 9 \\
\hline Techniek & 35 & 21 & 0 & 3 & 12 & 7 & 21 \\
\hline Economie & 10 & 8 & 13 & 3 & 10 & 4 & 52 \\
\hline Gezondheidszorg & 16 & 14 & 10 & 8 & 8 & 22 & 21 \\
\hline BOL niveau 3 & 18 & 11 & 9 & 8 & 11 & 15 & 27 \\
\hline Landbouw & 44 & 15 & 11 & 8 & 12 & 6 & 4 \\
\hline Techniek & - & - & - & - & - & - & - \\
\hline Economie & 22 & 8 & 7 & 11 & 7 & 13 & 32 \\
\hline Gezondheidszorg & 17 & 4 & 7 & 8 & 12 & 18 & 33 \\
\hline Gedrag en maatschappij & 7 & 23 & 13 & 7 & 10 & 18 & 22 \\
\hline B0L niveau 4 & 14 & 12 & 10 & 8 & 9 & 17 & 30 \\
\hline Landbouw & 32 & 17 & 5 & 7 & 9 & 9 & 21 \\
\hline Techniek & 17 & 16 & 14 & 9 & 11 & 12 & 21 \\
\hline Economie & 15 & 13 & 14 & 11 & 11 & 14 & 22 \\
\hline Gezondheidszorg & 13 & 9 & 5 & 1 & 2 & 17 & 52 \\
\hline Gedrag en maatschappij & 7 & 8 & 6 & 12 & 12 & 27 & 29 \\
\hline BBL & 14 & 11 & 10 & 10 & 10 & 18 & 27 \\
\hline BBL niveau 1 & 7 & 8 & 14 & 8 & 11 & 24 & 28 \\
\hline BBL niveau 2 & 17 & 11 & 12 & 10 & 11 & 16 & 25 \\
\hline Landbouw & 29 & 6 & 18 & 0 & 16 & 16 & 15 \\
\hline Techniek & 19 & 15 & 11 & 11 & 12 & 14 & 18 \\
\hline Economie & 11 & 7 & 13 & 14 & 6 & 10 & 39 \\
\hline Gezondheidszorg & 8 & 4 & 8 & 6 & 8 & 30 & 35 \\
\hline
\end{tabular}


Tabel A8.3

Grootte van de organisatie waarin schoolverlaters werkzaam zijn

\begin{tabular}{|c|c|c|c|c|c|c|c|}
\hline Opleidingssector & $\begin{array}{r}1 \mathrm{t} / \mathrm{m} 9 \\
\text { pers. } \\
\%\end{array}$ & $\begin{array}{r}10 \mathrm{t} / \mathrm{m} 24 \\
\text { pers. } \\
\%\end{array}$ & $\begin{array}{r}25 \mathrm{t} / \mathrm{m} 49 \\
\text { pers. } \\
\%\end{array}$ & $\begin{array}{r}50 \mathrm{t} / \mathrm{m} 99 \\
\text { pers. } \\
\%\end{array}$ & $\begin{array}{r}100 \mathrm{t} / \mathrm{m} 249 \\
\text { pers. } \\
\%\end{array}$ & $\begin{array}{r}250 \mathrm{t} / \mathrm{m} 999 \\
\text { pers. } \\
\%\end{array}$ & $\begin{array}{r}\geq 1000 \\
\text { pers } \\
\%\end{array}$ \\
\hline BBL niveau 3 & 14 & 13 & 10 & 12 & 11 & 17 & 24 \\
\hline Landbouw & 30 & 17 & 18 & 6 & 12 & 0 & 16 \\
\hline Techniek & - & - & - & - & - & - & - \\
\hline Economie & 5 & 10 & 13 & 23 & 15 & 17 & 17 \\
\hline Gezondheidszorg & 4 & 5 & 3 & 9 & 9 & 25 & 44 \\
\hline Gedrag en maatschappij & 7 & 29 & 7 & 4 & 7 & 30 & 15 \\
\hline BBL niveau 4 & 9 & 7 & 6 & 6 & 6 & 24 & 41 \\
\hline Landbouw & - & - & - & - & - & - & - \\
\hline Techniek & 11 & 8 & 12 & 11 & 14 & 23 & 21 \\
\hline Economie & 18 & 14 & 9 & 9 & 2 & 13 & 34 \\
\hline Gezondheidszorg & 4 & 1 & & 1 & 3 & 24 & 67 \\
\hline Gedrag en maatschappij & 5 & 3 & 10 & 5 & 8 & 39 & 29 \\
\hline HBO & 13 & 12 & 10 & 8 & 13 & 17 & 26 \\
\hline Landbouw & 20 & 12 & 9 & 6 & 14 & 20 & 20 \\
\hline Onderwijs & 6 & 24 & 24 & 11 & 17 & 13 & 5 \\
\hline Techniek & 11 & 13 & 10 & 9 & 14 & 14 & 29 \\
\hline Economie & 11 & 9 & 8 & 9 & 14 & 18 & 31 \\
\hline Gezondheidszorg & 23 & 13 & 5 & 4 & 4 & 14 & 38 \\
\hline Gedrag en maatschappij & 5 & 5 & 5 & 9 & 15 & 31 & 31 \\
\hline Taal en cultuur & 50 & 12 & 8 & 7 & 12 & 7 & 4 \\
\hline Totaal & 15 & 11 & 10 & 9 & 11 & 15 & 29 \\
\hline
\end{tabular}

- = te weinig waarnemingen

Bron: ROA (SIS)

Toelichting

Het betreft hier de grootte van de totale organisatie (inclusief eventuele andere vestigingen). 
Tabel A8.4

Vereist opleidingsniveau voor de huidige functie volgens de werkgever

\begin{tabular}{|c|c|c|c|}
\hline Opleidingssector & $\begin{array}{r}\text { lager } \\
\%\end{array}$ & $\begin{array}{r}\text { zelfde } \\
\%\end{array}$ & $\begin{array}{r}\text { hoger } \\
\%\end{array}$ \\
\hline HAVO/VWO & 46 & 25 & 30 \\
\hline HAVO & 41 & 32 & 28 \\
\hline Vwo & 52 & 15 & 33 \\
\hline VMBO & 14 & 39 & 47 \\
\hline Naarleerweg & & & \\
\hline Theoretisch & 5 & 41 & 53 \\
\hline Gemengd & 20 & 64 & 16 \\
\hline Kaderberoepsgericht & 13 & 48 & 39 \\
\hline Basisberoepsgericht & 21 & 27 & 52 \\
\hline Naar sector & & & \\
\hline Landbouw & 13 & 28 & 60 \\
\hline Techniek & 18 & 41 & 41 \\
\hline Economie & 22 & 39 & 39 \\
\hline Gezondheidszorg & 14 & 39 & 47 \\
\hline MBO & 29 & 61 & 10 \\
\hline BOL & 22 & 69 & 9 \\
\hline BOL niveau 1 & 43 & 41 & 16 \\
\hline BoL niveau 2 & 32 & 45 & 23 \\
\hline Landbouw & 14 & 69 & 16 \\
\hline Techniek & 28 & 55 & 17 \\
\hline Economie & 43 & 34 & 23 \\
\hline Gezondheidszorg & 26 & 43 & 32 \\
\hline BOL niveau 3 & 23 & 74 & 2 \\
\hline Landbouw & 41 & 59 & \\
\hline Techniek & - & - & - \\
\hline Economie & 29 & 63 & 7 \\
\hline Gezondheidszorg & 21 & 79 & \\
\hline Gedrag en maatschappij & 13 & 86 & 1 \\
\hline BoL niveau 4 & 15 & 79 & 6 \\
\hline Landbouw & 28 & 68 & 4 \\
\hline Techniek & 15 & 79 & 6 \\
\hline Economie & 22 & 68 & 10 \\
\hline Gezondheidszorg & 9 & 86 & 5 \\
\hline Gedrag en maatschappij & 9 & 89 & 3 \\
\hline BBL & 36 & 54 & 10 \\
\hline BBL niveau 1 & 49 & 36 & 15 \\
\hline BBL niveau 2 & 38 & 41 & 21 \\
\hline Landbouw & 46 & 41 & 13 \\
\hline Techniek & 40 & 39 & 22 \\
\hline Economie & 43 & 38 & 20 \\
\hline Gezondheidszorg & 24 & 55 & 21 \\
\hline BBL niveau 3 & 39 & 61 & 0 \\
\hline Landbouw & 46 & 54 & \\
\hline Techniek & 52 & 48 & \\
\hline Economie & 48 & 52 & \\
\hline Gezondheidszorg & 24 & 76 & \\
\hline Gedrag en maatschappij & & 96 & 4 \\
\hline
\end{tabular}


Tabel A8.4

Vereist opleidingsniveau voor de huidige functie volgens de werkgever

\begin{tabular}{|c|c|c|c|}
\hline Opleidingssector & $\begin{array}{r}\text { lager } \\
\%\end{array}$ & $\begin{array}{r}\text { zelfde } \\
\%\end{array}$ & $\begin{array}{r}\text { hoger } \\
\%\end{array}$ \\
\hline BBL niveau 4 & 18 & 79 & 3 \\
\hline Landbouw & - & - & . \\
\hline Techniek & 33 & 67 & \\
\hline Economie & 33 & 62 & 5 \\
\hline Gezondheidszorg & 5 & 92 & 3 \\
\hline Gedrag en maatschappij & 8 & 89 & 3 \\
\hline HBO & 18 & 80 & 2 \\
\hline Landbouw & 21 & 78 & 1 \\
\hline Onderwijs & 7 & 93 & 0 \\
\hline Techniek & 11 & 87 & 2 \\
\hline Economie & 20 & 77 & 3 \\
\hline Gezondheidszorg & 17 & 82 & 1 \\
\hline Gedrag en maatschappij & 33 & 67 & 1 \\
\hline Taal en cultuur & 22 & 72 & 6 \\
\hline Wo & 33 & 64 & 3 \\
\hline Landbouw & 36 & 62 & 2 \\
\hline Techniek & 31 & 68 & 1 \\
\hline Economie & 41 & 58 & 1 \\
\hline Gezondheidszorg & 11 & 77 & 12 \\
\hline Gedrag en maatschappij & 38 & 61 & 2 \\
\hline Taal en cultuur & 58 & 39 & 2 \\
\hline Recht en openbare orde & 21 & 77 & 2 \\
\hline Natuurwetenschappen & 31 & 68 & 1 \\
\hline Totaal & 26 & 62 & 12 \\
\hline
\end{tabular}

- = te weinig waarnemingen

Bron: ROA (SIS); VSNU/IVA, 2009

Toelichting

Vraag in de enquête:

Welk opleidingsniveau werd door uw werkgever voor deze functie minimaal vereist? 
Tabel A8.5

Vereiste opleidingsrichting voor de huidige functie volgens de werkgever

$\begin{array}{lrr}\text { Opleidingssector } & \begin{array}{r}\text { eigen/verwante } \\ \text { richting } \\ \%\end{array} & \begin{array}{r}\text { geen/andere } \\ \text { richting } \\ \%\end{array} \\ \text { VMBO } & 51 & 49 \\ \text { Naarleerweg } & & 57 \\ \text { Theoretisch } & 43 & 66 \\ \text { Gemengd } & 34 & 52 \\ \text { Kaderberoepsgericht } & 48 & 38 \\ \text { Basisberoepsgericht } & 62 & \end{array}$

$\begin{array}{lll}\text { Naarsector } & & 37 \\ \text { Landbouw } & 63 & 40 \\ \text { Techniek } & 60 & 62 \\ \text { Economie } & 38 & 46\end{array}$

MBO

$\begin{array}{ll}\text { BOL } & 71\end{array}$

\section{BOL niveau 1}

54

BOL niveau 2

Landbouw

Techniek

Economie

Gezondheidszorg

49
57
66
52
38

BOL niveau 3
Landbouw
Techniek
Economie
Gezondheidszorg
Gedrag en maatschappij

BOL niveau 4
Landbouw
Techniek
Economie
Gezondheidszorg
Gedrag en maatschappij

BBL

$\begin{array}{ll}\mathbf{5 8} & \mathbf{4 2} \\ 53 & 47 \\ 61 & 39 \\ 52 & 48 \\ 64 & 36\end{array}$

$\begin{array}{rr}76 & 24 \\ 56 & 44 \\ - & - \\ 74 & 26 \\ 82 & 18 \\ 83 & 17\end{array}$

\section{BBL niveau 1}

$76 \quad 24$

$\begin{array}{ll}67 & 33 \\ 78 & 32\end{array}$

$78 \quad 22$

$65-35$

$84-16$

$\begin{array}{ll}84 & 17\end{array}$

\section{BBL niveau 2}

69

Landbouw

Techniek

Economie

Gezondheidszorg

41

59

BBL niveau 3

Landbouw

Techniek

Economie

Gezondheidszorg

Gedrag en maatschappij

$\begin{array}{ll}61 & 39 \\ 52 & 48 \\ 62 & 38 \\ 50 & 50 \\ 73 & 27\end{array}$

$\begin{array}{rr}78 & 22 \\ 74 & 26 \\ 71 & 29 \\ 69 & 31 \\ 90 & 10 \\ 96 & 4\end{array}$


Tabel A8.5

Vereiste opleidingsrichting voor de huidige functie volgens de werkgever

$\begin{array}{lrr}\text { Opleidingssector } & \text { eigen/verwante } & \text { geen/andere } \\ & \text { richting } & \text { richting } \\ \end{array}$

BBL niveau 4

Landbouw

Techniek

Economie

Gezondheidszorg

Gedrag en maatschappij

$\begin{array}{rr}\mathbf{8 3} & \mathbf{1 7} \\ - & - \\ 84 & 16 \\ 61 & 39 \\ 91 & 9 \\ 95 & 5\end{array}$

HBO

Landbouw

Onderwijs

Techniek

Economie

Gezondheidszorg

Gedrag en maatschappij

Taal en cultuur

$\begin{array}{lr}\mathbf{8 0} & \mathbf{2 0} \\ 75 & 25 \\ 94 & 6 \\ 87 & 13 \\ 65 & 35 \\ 93 & 7 \\ 88 & 12 \\ 82 & 18\end{array}$

wo

Techniek

Economie

Gezondheidszorg

Gedrag en maatschappij

Taal en cultuur

Recht en openbare orde

Natuurwetenschappen

$73 \quad 27$

78

$70 \quad 30$

$85-15$

$70 \quad 30$

$54 \quad 46$

$\begin{array}{ll}81 & 19\end{array}$

70

= te weinig waarnemingen

Bron: ROA (SIS);VSNU/IVA, 2009

Toelichting

Vraag in de enquête:

Welke opleidingsrichting werd door uw werkgever voor deze functie vereist? 
Tabel A8.6

Benutting van kennis en vaardigheden

Opleidingssector

VMBO

Naar leerweg

Theoretisch

Gemengd

60

Kaderberoepsgericht

60

Basisberoepsgericht

Naar sector

Landbouw

Techniek

Economie

Gezondheidszorg

BOL

BOL niveau 1

BOL niveau 2

Landbouw

Techniek

Economie

Gezondheidszorg

BOL niveau 3

Landbouw

Techniek

Economie

Gezondheidszorg

Gedrag en maatschappij

BOL niveau 4

Techniek

Economie

Gezondheidszorg

BBL niveau 1

BBL niveau 2

Landbouw

Techniek

Economie

Gezondheidszorg

BBL niveau 3

Landbouw

Techniek

Economie

Gezondheidszorg

72
70

Gedrag en maatschappij 
Tabel A8.6

Benutting van kennis en vaardigheden

Opleidingssector

BBL niveau 4

Landbouw

Techniek

Economie

Gezondheidszorg

Gedrag en maatschappij

HBO

Landbouw

Onderwijs

Techniek

Economie

Gezondheidszorg

Gedrag en maatschappij

Totaal

- = te weinig waarnemingen

Bron: ROA (SIS)

\section{Toelichting}

Vraag in de enquête:

In welke mate worden in uw huidige functie uw kennis en vaardigheden benut ( 1 'helemaal niet' tot en met 5 'in sterke mate'). Vermeld is het percentage van antwoordcategorie 4 en 5. 
Tabel A8.7

Kennis en vaardigheden schieten tekort

Opleidingssector

VMBO

11

Naar leerweg

Theoretisch

Gemengd

Kaderberoepsgericht

Basisberoepsgericht

$\begin{array}{lr}\text { Naar sector } & 15 \\ \text { Landbouw } & 8 \\ \text { Techniek } & 6 \\ \text { Economie } & 17 \\ \text { Gezondheidszorg } & \mathbf{1 1} \\ \text { MBO } & \mathbf{1 2} \\ \text { BOL } & \mathbf{2 0} \\ \text { BOL niveau 1 } & 11 \\ \text { BOL niveau 2 } & 14 \\ \text { Landbouw } & 10 \\ \text { Techniek } & 8 \\ \text { Economie } & 19 \\ \text { Gezondheidszorg } & 19\end{array}$

BOL niveau 3

Landbouw

Economie

Gezondheidszorg

Gedrag en maatschappij

\section{BOL niveau 4}

Landbouw

Techniek

Economie

Gezondheidszorg

Gedrag en maatschappij

14

10

19

BBL

BBL niveau 1

BBL niveau 2

Techniek

Economie

Gezondheidszorg

BBL niveau 3

Landbouw

Techniek

Economie

Gezondheidszorg

Gedrag en maatschappij

BBL niveau 4

Techniek

Economie

Gezondheidszorg

- 
Tabel A8.7

Kennis en vaardigheden schieten tekort

Opleidingssector

HBO

Landbouw

Onderwijs

Techniek

Economie

Gezondheidszorg

Gedrag en maatschappij

\section{Totaal}

- = te weinig waarnemingen

Bron: ROA (SIS)

\section{Toelichting}

Vraag in de enquête:

In welke mate schieten uw kennis en vaardigheden tekort voor uw huidige functie ( 1 'helemaal niet' tot en met 5 'in sterke mate')? Vermeld is het percentage van antwoordcategorie 4 en 5. 
Tabel A8.8

Oordeel van de werkende schoolverlaters over de aansluiting tussen de afgesloten opleiding en de huidige functie

$\begin{array}{lcccr}\text { Opleidingssector } & \begin{array}{r}\text { goed } \\ \%\end{array} & \begin{array}{r}\text { voldoende } \\ \%\end{array} & \begin{array}{r}\text { matig } \\ \%\end{array} & \begin{array}{r}\text { slecht } \\ \%\end{array} \\ \text { VMBO } & \mathbf{2 7} & \mathbf{5 0} & \mathbf{1 3} & \mathbf{1 0} \\ \text { Naarleerweg } & & & & 11 \\ \text { Theoretisch } & 25 & 46 & 17 & 18 \\ \text { Gemengd } & 14 & 47 & 13 & 12 \\ \text { Kaderberoepsgericht } & 23 & 51 & 10 & 5 \\ \text { Basisberoepsgericht } & 33 & 52 & \end{array}$

\begin{tabular}{|c|c|c|c|c|}
\hline \multicolumn{5}{|l|}{ Naar sector } \\
\hline Landbouw & 25 & 48 & 15 & 12 \\
\hline Techniek & 29 & 54 & 10 & 7 \\
\hline Economie & 24 & 54 & 13 & 8 \\
\hline Gezondheidszorg & 29 & 46 & 13 & 12 \\
\hline MBO & 33 & 47 & 14 & 6 \\
\hline BOL & 28 & 48 & 16 & 8 \\
\hline BOL niveau 1 & 28 & 40 & 10 & 22 \\
\hline BOL niveau 2 & 31 & 47 & 12 & 10 \\
\hline Landbouw & 23 & 51 & 16 & 10 \\
\hline Techniek & 25 & 51 & 12 & 12 \\
\hline Economie & 34 & 44 & 9 & 13 \\
\hline Gezondheidszorg & 37 & 45 & 15 & 2 \\
\hline BOL niveau 3 & 32 & 44 & 19 & 5 \\
\hline Landbouw & 47 & 32 & 11 & 9 \\
\hline Techniek & - & - & - & - \\
\hline Economie & 23 & 53 & 18 & 6 \\
\hline Gezondheidszorg & 33 & 47 & 19 & 2 \\
\hline Gedrag en maatschappij & 37 & 37 & 23 & 3 \\
\hline BOL niveau 4 & 25 & 50 & 16 & 8 \\
\hline Landbouw & 21 & 51 & 12 & 15 \\
\hline Techniek & 17 & 55 & 17 & 11 \\
\hline Economie & 27 & 46 & 16 & 11 \\
\hline Gezondheidszorg & 29 & 44 & 23 & 5 \\
\hline Gedrag en maatschappij & 30 & 56 & 12 & 3 \\
\hline BBL & 37 & 47 & 12 & 4 \\
\hline BBL niveau 1 & 30 & 54 & 15 & 1 \\
\hline BBL niveau 2 & 40 & 43 & 12 & 6 \\
\hline Landbouw & 36 & 32 & 26 & 5 \\
\hline Techniek & 40 & 45 & 9 & 6 \\
\hline Economie & 25 & 49 & 18 & 8 \\
\hline Gezondheidszorg & 59 & 35 & 4 & 2 \\
\hline BBL niveau 3 & 37 & 48 & 12 & 3 \\
\hline Landbouw & 46 & 39 & 11 & 3 \\
\hline Techniek & 34 & 46 & 15 & 5 \\
\hline Economie & 30 & 50 & 15 & 5 \\
\hline Gezondheidszorg & 42 & 51 & 7 & \\
\hline Gedrag en maatschappij & 41 & 59 & & \\
\hline
\end{tabular}


Tabel A8.8

Oordeel van de werkende schoolverlaters over de aansluiting tussen de afgesloten opleiding en de huidige functie

$\begin{array}{rrrrr}\text { Opleidingssector } & \text { goed } & \text { voldoende } & \text { matig } & \text { slecht } \\ & \% & \% & \% & \%\end{array}$

$\begin{array}{lrrrr}\text { BBL niveau 4 } & \mathbf{3 1} & \mathbf{5 1} & \mathbf{1 3} & \mathbf{5} \\ \text { Landbouw } & - & - & 13 & - \\ \text { Techniek } & 33 & 54 & 18 & 7 \\ \text { Economie } & 27 & 49 & 11 & 5 \\ \text { Gezondheidszorg } & 31 & 53 & 13 & 5 \\ \text { Gedrag en maatschappij } & 32 & 50 & \end{array}$

$\begin{array}{lllrr}\text { HBO } & \mathbf{3 1} & \mathbf{4 5} & \mathbf{1 7} & \mathbf{7} \\ \text { Landbouw } & 33 & 46 & 15 & 6 \\ \text { Onderwijs } & 42 & 45 & 10 & 3 \\ \text { Techniek } & 28 & 51 & 16 & 5 \\ \text { Economie } & 25 & 44 & 21 & 10 \\ \text { Gezondheidszorg } & 37 & 45 & 15 & 3 \\ \text { Gedrag en maatschappij } & 29 & 46 & 13 & 15 \\ \text { Taal en cultuur } & 40 & 33 & \mathbf{1 5} & \mathbf{7} \\ \text { Totaal } & & \mathbf{4 7} & & \end{array}$

- = te weinig waarnemingen

Bron: ROA (SIS)

Toelichting

Vraag in de enquête:

Hoe vindt $u$ de aansluiting tussen uw [...] opleiding en uw huidige functie? 
Tabel A8.9

Tevredenheid met huidige functie

Opleidingssector

VMBO

Naar leerweg

Theoretisch

Gemengd

Kaderberoepsgericht

80
86

Basisberoepsgericht

Naar sector

Landbouw

Techniek

92

Economie

84

Gezondheidszorg

MBO

70

BOL

BOL niveau 1

BOL niveau 2

Techniek

Economie

Gezondheidszorg

BOL niveau 3

Landbouw

Techniek

Economie

Gezondheidszorg

Gedrag en maatschappij

BOL niveau 4

Landbouw

Techniek

Economie

Gezondheidszor

Gedrag en maatschappij

BBL niveau 1

BBL niveau 2

Landbouw

63

Techniek

Economie

Gezondheidszorg

BBL niveau 3

Landbouw

Techniek

Economie

Gezondheidszorg

65

Gedrag en maatschappij 
Tabel A8.9

Tevredenheid met huidige functie

Opleidingssector

BBL niveau 4

Landbouw

Techniek

58

Economie

Gezondheidszorg

Gedrag en maatschappi

HBO

Landbouw

Onderwijs

Techniek

Economie

Gezondheidszorg

Gedrag en maatschappij

wo

Landbouw

Techniek

Economie

Gezondheidszorg

Gedrag en maatschappij

Recht en openbare orde

Natuurwetenschappen

- = te weinig waarnemingen

Bron: ROA (SIS); VSNU/IVA, 2009

Toelichting

Vraag in de enquête:

Hoe tevreden bent u met uw huidige functie ( 1 'zeer ontevreden' tot en met 5 'zeer tevreden'. Vermeld is het percentage van antwoordcategorie 4 en 5. 
Tabel A9.1

Werkloosheid

\begin{tabular}{|c|c|c|}
\hline & $\begin{array}{r}\text { aanbieden op arbeidsmarkt } \\
\%\end{array}$ & werkloosheid \\
\hline HAVO/VWO & 10 & \\
\hline HAVO & 12 & \\
\hline vW0 & 9 & \\
\hline VMBO & 28 & \\
\hline Naar leerweg & & \\
\hline Theoretisch & 17 & \\
\hline Gemengd & 21 & \\
\hline Kaderberoepsgericht & 33 & \\
\hline Basisberoepsgericht & 44 & \\
\hline
\end{tabular}

\begin{tabular}{|c|c|c|}
\hline Naar sector & & \\
\hline Landbouw & 32 & 6 \\
\hline Techniek & 53 & 2 \\
\hline Economie & 34 & 10 \\
\hline Gezondheidszorg & 28 & 7 \\
\hline MBO & 74 & 6 \\
\hline BOL & 59 & 10 \\
\hline BOL niveau 1 & 58 & 30 \\
\hline BOL niveau 2 & 57 & 12 \\
\hline Landbouw & 67 & 18 \\
\hline Techniek & 67 & 9 \\
\hline Economie & 55 & 12 \\
\hline Gezondheidszorg & 48 & 15 \\
\hline BOL niveau 3 & 71 & 11 \\
\hline Landbouw & 63 & 13 \\
\hline Techniek & 89 & 18 \\
\hline Economie & 63 & 18 \\
\hline Gezondheidszorg & 79 & 5 \\
\hline Gedrag en maatschappij & 74 & 9 \\
\hline
\end{tabular}

\begin{tabular}{|c|c|c|}
\hline BOL niveau 4 & 56 & 6 \\
\hline Landbouw & 57 & 6 \\
\hline Techniek & 55 & 5 \\
\hline Economie & 50 & 8 \\
\hline Gezondheidszorg & 67 & 4 \\
\hline Gedrag en maatschappij & 55 & 5 \\
\hline BBL & 95 & 3 \\
\hline BBL niveau 1 & 90 & 9 \\
\hline BBL niveau 2 & 95 & 3 \\
\hline Landbouw & 98 & 3 \\
\hline Techniek & 96 & 4 \\
\hline Economie & 93 & 3 \\
\hline Gezondheidszorg & 91 & 0 \\
\hline BBL niveau 3 & 96 & 3 \\
\hline Landbouw & 100 & $v$ \\
\hline Techniek & 98 & 2 \\
\hline Economie & 93 & 10 \\
\hline Gezondheidszorg & 95 & 0 \\
\hline Gedrag en maatschappij & 93 & 4 \\
\hline
\end{tabular}


Tabel A9.1

Werkloosheid

$\begin{array}{lrr} & \text { aanbieden op arbeidsmarkt } & \text { werkloosheid } \\ \text { BBL niveau 4 } & \% & \mathbf{9} \\ \text { Landbouw } & 94 & \mathbf{1} \\ \text { Techniek } & 89 & 0 \\ \text { Economie } & 95 & 2 \\ \text { Gezondheidszorg } & 98 & 1 \\ \text { Gedrag en maatschappij } & 95 & 0\end{array}$

HBO

$\begin{array}{ll}83 & \mathbf{6} \\ 84 & 5 \\ 90 & 3 \\ 78 & 6 \\ 78 & 8 \\ 90 & 2 \\ 87 & 4 \\ 88 & 9\end{array}$

Landbouw

Onderwijs

Techniek

Economie

Gezondheidszorg

Gedrag en maatschappij

Taal en cultuur

$\begin{array}{ll}\mathbf{9 4} & \mathbf{5} \\ 96 & 9 \\ 98 & 5 \\ 96 & 5 \\ 88 & 2 \\ 94 & 6 \\ 89 & 8 \\ 94 & 9 \\ 95 & 2\end{array}$

wo

Natuurwetenschappen

54

Bron: ROA (SIS); VSNU/IVA, 2009

\section{Toelichting}

Het werkloosheidspercentage heeft betrekking op de werkloze beroepsbevolking: schoolverlaters zonder werk (of met werk van minder dan 12 uur per week) die op zoek zijn naar betaald werk. Daarbij is tevens als voorwaarde gesteld dat de maatschappelijke positie niet scholier of student is. 
Tabel A9.2

Werkloosheid tot eerste baan

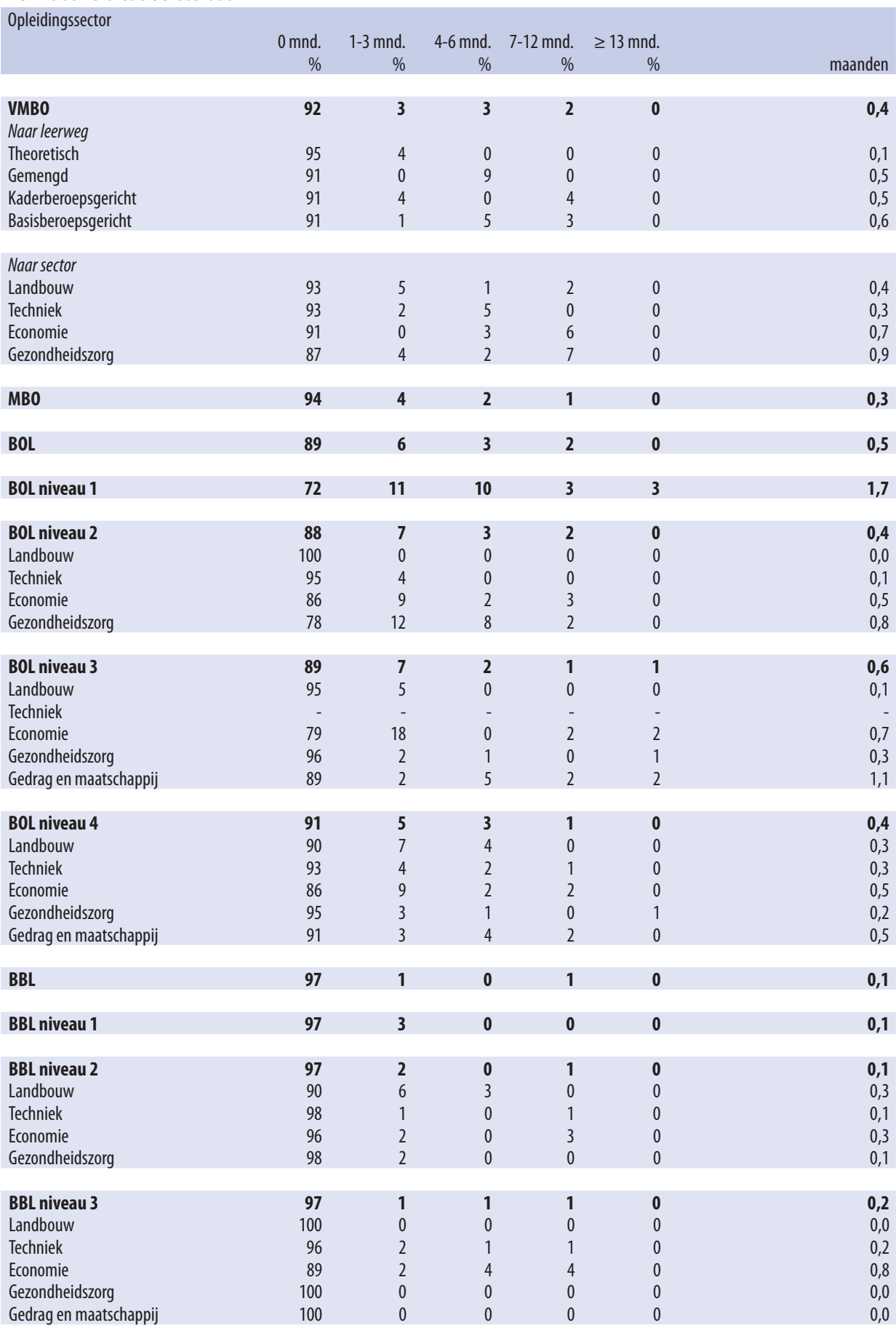


Tabel A9.2

Werkloosheid tot eerste baan

\begin{tabular}{|c|c|c|c|c|c|c|}
\hline Opleidingssector & $\begin{array}{r}0 \text { mnd. } \\
\%\end{array}$ & $\begin{array}{r}1-3 \text { mnd. } \\
\%\end{array}$ & $\begin{array}{r}4-6 \text { mnd. } \\
\%\end{array}$ & $\begin{array}{r}\text { 7-12 mnd. } \\
\%\end{array}$ & $\begin{array}{r}\geq 13 \text { mnd. } \\
\%\end{array}$ & maanden \\
\hline BBL niveau 4 & 100 & 0 & 0 & 0 & 0 & 0,0 \\
\hline Landbouw & - & - & - & - & - & - \\
\hline Techniek & 100 & 0 & 0 & 0 & 0 & 0,0 \\
\hline Economie & 100 & 0 & 0 & 0 & 0 & 0,0 \\
\hline Gezondheidszorg & 99 & 1 & 0 & 0 & 0 & 0,0 \\
\hline \multirow[t]{2}{*}{ Gedrag en maatschappij } & 100 & 0 & 0 & 0 & 0 & 0,0 \\
\hline & & & & & & 0,1 \\
\hline HBO & 79 & 14 & 5 & 2 & 1 & 0,9 \\
\hline Landbouw & 82 & 14 & 3 & 0 & 1 & 0,5 \\
\hline Onderwijs & 83 & 9 & 3 & 2 & 2 & 0,9 \\
\hline Techniek & 84 & 11 & 3 & 1 & 1 & 0,6 \\
\hline Economie & 73 & 17 & 6 & 3 & 1 & 1,0 \\
\hline Gezondheidszorg & 85 & 10 & 3 & 1 & 1 & 0,6 \\
\hline Gedrag en maatschappij & 77 & 15 & 6 & 2 & 0 & 0,8 \\
\hline Taal en cultuur & 74 & 13 & 8 & 3 & 2 & 1,2 \\
\hline Totaal & 89 & 6 & 3 & 2 & 0 & 0,5 \\
\hline
\end{tabular}

- = te weinig waarnemingen

Bron: ROA (SIS) 
Tabel A9.3

Percentage werkende schoolverlaters dat op zoek is naar een andere baan

Opleidingssector

$\begin{array}{lr}\text { HAVONWO } & \mathbf{1 3} \\ \text { HAVO } & 11 \\ \text { VWO } & 15 \\ \text { VMBO } & \mathbf{6} \\ \text { Naarleerweg } & 7 \\ \text { Theoretisch } & 0 \\ \text { Gemengd } & 7 \\ \text { Kaderberoepsgericht } & 5 \\ \text { Basisberoepsgericht } & 5\end{array}$

Naar sector

Landbouw

Techniek

Economie

Gezondheidszorg

MBO

BOL

BOL niveau 1

BOL niveau 2

Techniek

Economie

Gezondheidszorg

BOL niveau 3

Landbouw

Techniek

Economie

Gezondheidszorg

Gedrag en maatschappij

B0L niveau 4

Landbouw

Techniek

Economie

Gezondheidszorg

Gedrag en maatschappij

BBL

BBL niveau 1

BBL niveau 2

Landbouw

Techniek

Economie

Gezondheidszorg

BBL niveau 3

Landbouw

Techniek

Economie

Gezondheidszorg

Gedrag en maatschappij 
Tabel A9.3

Percentage werkende schoolverlaters dat op zoek is naar een andere baan Opleidingssector

BBL niveau 4

Landbouw

Techniek

Economie

Gezondheidszorg

Gedrag en maatschappij

HBO

Landbouw

Onderwijs

Techniek

Economie

Gezondheidszorg

Gedrag en maatschappij

13

Taal en cultuur

Totaal

- = te weinig waarnemingen

Bron: ROA (SIS) 
Tabel A9.4

Aard van het dienstverband van werkende schoolverlaters

\begin{tabular}{|c|c|c|c|c|c|}
\hline Opleidingssector & $\begin{array}{r}\text { leer/werk- } \\
\text { overeenkomst } \\
\%\end{array}$ & $\begin{array}{r}\text { uitzend-, } \\
\text { oproepkracht } \\
\%\end{array}$ & $\begin{array}{r}\text { loondienst } \\
\text { werkgever } \\
\%\end{array}$ & $\begin{array}{r}\text { bedrijf ouders/ } \\
\text { partner } \\
\%\end{array}$ & $\begin{array}{r}\text { eigen bedrijf/free-lance } \\
\%\end{array}$ \\
\hline HAVO/VWO & 15 & 15 & 68 & 2 & 0 \\
\hline HAVO & 27 & 9 & 64 & 0 & 0 \\
\hline vwo & 0 & 23 & 73 & 4 & 0 \\
\hline $\begin{array}{l}\text { VMBO } \\
\text { Naar leerweg }\end{array}$ & 47 & 7 & 44 & 1 & 1 \\
\hline Theoretisch & 44 & 9 & 46 & 0 & 0 \\
\hline Gemengd & 41 & 0 & 58 & 0 & 0 \\
\hline Kaderberoepsgericht & 45 & 2 & 51 & 2 & 0 \\
\hline Basisberoepsgericht & 50 & 10 & 36 & 2 & 2 \\
\hline Naar sector & & & & & \\
\hline Landbouw & 60 & 4 & 34 & 1 & 1 \\
\hline Techniek & 63 & 8 & 29 & 0 & 0 \\
\hline Economie & 27 & 4 & 69 & 0 & 0 \\
\hline Gezondheidszorg & 34 & 6 & 51 & 7 & 2 \\
\hline MBO & 16 & 4 & 78 & 0 & 2 \\
\hline BOL & 13 & 6 & 78 & 0 & 2 \\
\hline BOL niveau 1 & 30 & 7 & 51 & 0 & 12 \\
\hline BOL niveau 2 & 29 & 9 & 61 & 0 & 1 \\
\hline Landbouw & 26 & 9 & 65 & 0 & 0 \\
\hline Techniek & 39 & 7 & 54 & 0 & 1 \\
\hline Economie & 23 & 9 & 66 & 0 & 2 \\
\hline Gezondheidszorg & 28 & 10 & 62 & 0 & 0 \\
\hline BOL niveau 3 & 11 & 6 & 81 & 0 & 2 \\
\hline Landbouw & 19 & 4 & 73 & 0 & 4 \\
\hline Techniek & - & - & - & - & - \\
\hline Economie & 5 & 4 & 90 & 0 & 0 \\
\hline Gezondheidszorg & 14 & 4 & 79 & 0 & 2 \\
\hline Gedrag en maatschappij & 10 & 10 & 77 & 1 & 3 \\
\hline BoL niveau 4 & 5 & 5 & 86 & 1 & 2 \\
\hline Landbouw & 1 & 7 & 87 & 2 & 3 \\
\hline Techniek & 3 & 4 & 88 & 2 & 4 \\
\hline Economie & 8 & 7 & 82 & 1 & 2 \\
\hline Gezondheidszorg & 10 & 5 & 83 & 1 & 1 \\
\hline Gedrag en maatschappij & 2 & 6 & 91 & 0 & 1 \\
\hline BBL & 18 & 2 & 78 & 0 & 1 \\
\hline BBL niveau 1 & 19 & 3 & 78 & 0 & 0 \\
\hline BBL niveau 2 & 20 & 3 & 76 & 0 & 1 \\
\hline Landbouw & 19 & 6 & 71 & 0 & 3 \\
\hline Techniek & 26 & 2 & 71 & 0 & 1 \\
\hline Economie & 7 & 3 & 90 & 0 & 0 \\
\hline Gezondheidszorg & 16 & 2 & 79 & 0 & 2 \\
\hline
\end{tabular}


Tabel A9.4

Aard van het dienstverband van werkende schoolverlaters

\begin{tabular}{|c|c|c|c|c|c|}
\hline Opleidingssector & $\begin{array}{r}\text { leer/werk- } \\
\text { overeenkomst } \\
\%\end{array}$ & $\begin{array}{r}\text { uitzend-, } \\
\text { oproepkracht } \\
\%\end{array}$ & $\begin{array}{r}\text { loondienst } \\
\text { werkgever } \\
\%\end{array}$ & $\begin{array}{r}\text { bedrijf ouders/ } \\
\text { partner } \\
\%\end{array}$ & eigen bedrijf/free-lance \\
\hline BBL niveau 3 & 16 & 3 & 79 & 0 & 2 \\
\hline Landbouw & 12 & 3 & 85 & 0 & 0 \\
\hline Techniek & 13 & 3 & 80 & 1 & 3 \\
\hline Economie & 14 & 2 & 84 & 0 & 0 \\
\hline Gezondheidszorg & 20 & 3 & 75 & 0 & 1 \\
\hline Gedrag en maatschappij & 29 & 0 & 71 & 0 & 0 \\
\hline BBL niveau 4 & 15 & 1 & 81 & 1 & 2 \\
\hline Landbouw & - & - & - & - & - \\
\hline Techniek & 10 & 0 & 87 & 0 & 3 \\
\hline Economie & 14 & 5 & 73 & 5 & 5 \\
\hline Gezondheidszorg & 24 & 1 & 74 & 0 & 0 \\
\hline Gedrag en maatschappij & 11 & 0 & 89 & 0 & 0 \\
\hline HBO & 0 & 6 & 87 & 0 & 6 \\
\hline Landbouw & 0 & 4 & 87 & 1 & 7 \\
\hline Onderwijs & 0 & 12 & 88 & 0 & 1 \\
\hline Techniek & 0 & 4 & 92 & 0 & 4 \\
\hline Economie & 0 & 7 & 88 & 1 & 4 \\
\hline Gezondheidszorg & 0 & 4 & 93 & 0 & 3 \\
\hline Gedrag en maatschappij & 0 & 5 & 94 & 0 & 1 \\
\hline Taal en cultuur & 0 & 4 & 46 & 0 & 50 \\
\hline Totaal & 16 & 6 & 75 & 1 & 3 \\
\hline
\end{tabular}

- = te weinig waarnemingen

Bron: ROA (SIS) 
Tabel A9.5

Percentage werkende schoolverlaters met een flexibele aanstelling

Opleidingssector

$\begin{array}{lr}\text { HAVONWO } & \mathbf{4 2} \\ \text { HAVO } & 40 \\ \text { VWO } & 43 \\ \text { VMBO } & \mathbf{6 3} \\ \text { Naarleerweg } & \\ \text { Theoretisch } & 56 \\ \text { Gemengd } & 77 \\ \text { Kaderberoepsgericht } & 50 \\ \text { Basisberoepsgericht } & 78\end{array}$

Naar sector

Landbouw

Techniek

Economie

Gezondheidszorg

MBO

BOL

BOL niveau 1

BOL niveau 2

Techniek

Economie

Gezondheidszorg

BOL niveau 3

Landbouw $\quad 43$

Techniek 26

Economie $\quad 48$

Gezondheidszorg 38

Gedrag en maatschappij 46

BOL niveau 4

Landbouw

Techniek

Economie $\quad 47$

Gezondheidszorg

Gedrag en maatschappij

BBL

BBL niveau 1

BBL niveau 2

Landbouw

\begin{tabular}{ll} 
Techniek & 29 \\
\hline
\end{tabular}

Economie

Gezondheidszorg

BBL niveau 3 25

Landbouw

\begin{tabular}{ll} 
Techniek & 20 \\
\hline
\end{tabular}

Economie

Gezondheidszorg

Gedrag en maatschappij 
Tabel A9.5

Percentage werkende schoolverlaters met een flexibele aanstelling

Opleidingssector

BBL niveau 4

Landbouw

Techniek

Economie

Gezondheidszorg

Gedrag en maatschappij

HBO

Landbouw

Onderwijs

Economie

Gezondheidszorg

Gedrag en maatschappij

Taal en cultuur

Totaal

- = te weinig waarnemingen

Bron: ROA (SIS)

Toelichting

Een flexibele aanstelling betreft een aanstelling als uitzendkracht, oproepkracht e.d. of een aanstelling in tijdelijke dienst. 
Tabel A9.6

Beloning van werkende schoolverlaters

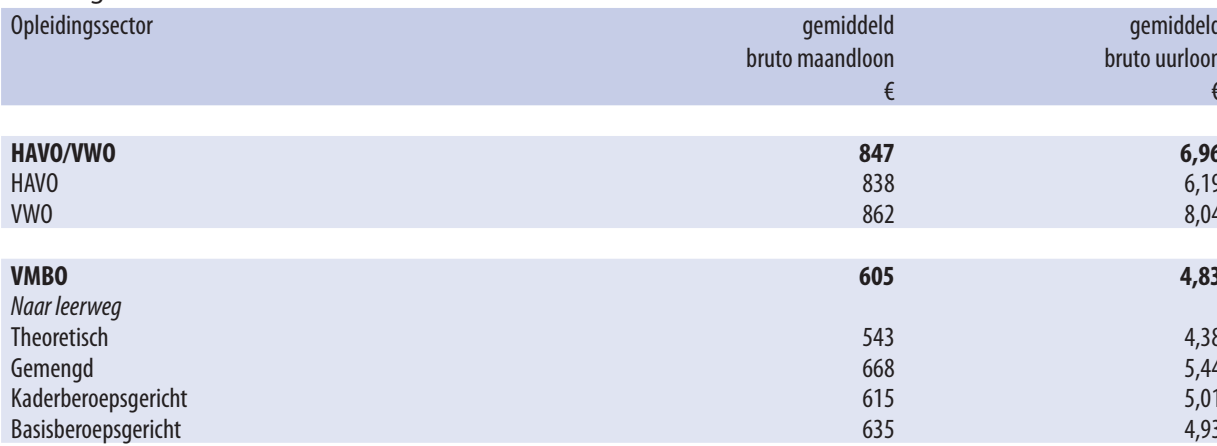

\begin{tabular}{|c|c|c|}
\hline Naar sector & & \\
\hline Landbouw & 597 & 4,68 \\
\hline Techniek & 745 & 5,34 \\
\hline Economie & 583 & 4,85 \\
\hline Gezondheidszorg & 477 & 4,65 \\
\hline MBO & 1.483 & 10,37 \\
\hline BOL & 1.339 & 9,57 \\
\hline BOL niveau 1 & 877 & 6,57 \\
\hline BOL niveau 2 & 1.069 & 7,85 \\
\hline Landbouw & 844 & 6,45 \\
\hline Techniek & 1.123 & 7,54 \\
\hline Economie & 1.134 & 8,04 \\
\hline Gezondheidszorg & 967 & 8,43 \\
\hline B0L niveau 3 & 1.312 & 10,04 \\
\hline Landbouw & 1.130 & 7,94 \\
\hline Techniek & - & - \\
\hline Economie & 1.462 & 9,60 \\
\hline Gezondheidszorg & 1.245 & 10,11 \\
\hline Gedrag en maatschappij & 1.263 & 10,75 \\
\hline BOL niveau 4 & 1.505 & 10,36 \\
\hline Landbouw & 1.410 & 9,19 \\
\hline Techniek & 1.775 & 10,93 \\
\hline Economie & 1.428 & 9,42 \\
\hline Gezondheidszorg & 1.549 & 10,91 \\
\hline Gedrag en maatschappij & 1.310 & 10,71 \\
\hline BBL & 1.613 & 11,09 \\
\hline BBL niveau 1 & 1.406 & 9,28 \\
\hline BBL niveau 2 & 1.508 & 10,12 \\
\hline Landbouw & 1.372 & 9,01 \\
\hline Techniek & 1.658 & 10,30 \\
\hline Economie & 1.330 & 8,96 \\
\hline Gezondheidszorg & 1.260 & 11,60 \\
\hline
\end{tabular}


Tabel A9.6

Beloning van werkende schoolverlaters

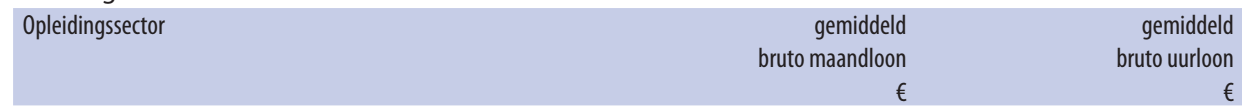

$\begin{array}{lrr}\text { BBL niveau } 3 & 1.669 & 11,72\end{array}$

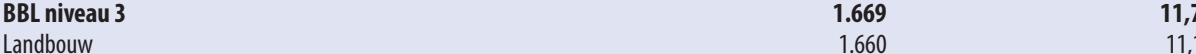

$\begin{array}{lll}\text { Techniek } & 1.907 & 11,86\end{array}$

$\begin{array}{lrr}\text { Economie } & 1.278 & 8,56\end{array}$

$\begin{array}{lrr}\text { Gezondheidszorg } & 1.521 & 13,08\end{array}$

$\begin{array}{lll}\text { Gedrag en maatschappij } & 1.439 & 11,89\end{array}$

BBL niveau 4

$1.861 \quad 13,13$

Landbouw

Techniek

Economie

2.232

13,96

Gezondheidszorg

$1.719-11,45$

Gedrag en maatschappij

$1.915-14,32$

HBO

1.505

Landbouw

2.034

13,36

Onderwijs

2.096

12,88

Techniek

1.936

13,48

Economie

2.320

13,92

Gezondheidszorg

$\begin{array}{ll}2.138 & 13,17\end{array}$

2.138

14,68

Gedrag en maatschappij

1.854

Taal en cultuur

1.357

Wo

2.511

15,76

Landbouw

2.208

13,71

Techniek

2.703

15,92

Economie

2.795

16,35

Gezondheidszorg

$2.738-16,88$

Gedrag en maatschappij

2.309

15,72

Taal en cultuur

2.136

14,47

Recht en openbare orde

2.732

16,34

Natuurwetenschappen

2.437

15,02

Totaal

1.628

11,02

- = te weinig waarnemingen

Bron: ROA (SIS);VSNU/IVA, 2009

Toelichting

Dit betreft het bruto inkomen in de hoofdfunctie. Dit is inclusief toeslagen maar exclusief inkomen uit overwerk. Er is hier niet gecorrigeerd voor verschillen in leeftijd van de schoolverlaters. 
Tabel A9.7

Percentage werkende schoolverlaters met een deeltijdaanstelling en wekelijkse arbeidsduur Opleidingssector deeltijdaanstelling $\%$ arbeidsduur uren

HAVO/VWO
HAVO
VWO
VMBO
Naarleerweg
Theoretisch
Gemengd
Kaderberoepsgericht
Basisberoepsgericht

58

$53-30,1$

66

27,1

65

29,2

Naar sector

Landbouw

Techniek

Economie

Gezondheidszorg

MBO

\section{7}

BOL

63

BOL niveau 1

52

BOL niveau 2

Landbouw

Techniek

Economie

Gezondheidszorg

\section{BOL niveau 3}

Techniek

Economie

Gezondheidszorg

Gedrag en maatschappij

\section{BOL niveau 4}

\section{Landbouw}

Techniek

Economie

Gezondheidszorg

Gedrag en maatschappij

BBL

BBL niveau 1

BBL niveau 2

Techniek

Economie

Gezondheidszorg

BBL niveau 3

$\begin{array}{ll}47 & 34,2 \\ 77 & 27,3 \\ & 27,3\end{array}$


Tabel A9.7

Percentage werkende schoolverlaters met een deeltijdaanstelling en wekelijkse arbeidsduur Opleidingssector deeltijdaanstelling $\%$ arbeidsduur uren

\section{BBL niveau 4}

Landbouw

Techniek

Economie

Gezondheidszorg

Gedrag en maatschappij

75

Onderwijs

Techniek

Economie

Gezondheidszorg

Gedrag en maatschappij

Taal en cultuur

WO

Landbouw

Techniek

Economie

Gezondheidszorg

Gedrag en maatschappij

Taal en cultuur

Recht en openbare orde

Natuurwetenschappen

Totaal

$\begin{array}{rr}20 & 38,0 \\ 15 & 39,0 \\ 6 & 39,9 \\ 6 & 40,5 \\ 16 & 38,6 \\ 37 & 35,5 \\ 37 & 35,7 \\ 9 & 39,2 \\ 13 & 38,5 \\ & \\ 39 & 34,0\end{array}$

- = te weinig waarnemingen

Bron: ROA (SIS); VSNU/IVA, 2009

Toelichting

De arbeidsduur betreft zowel het aantal uren in de hoofdfunctie als het aantal uren in eventuele nevenfuncties (HBO en WO).

Een deeltijdaanstelling is een aanstelling met minder dan 33 arbeidsuren per week. 
Tabel A9.8

Percentage werkende schoolverlaters waarvan huidige functie goede carrièremogelijkheden biedt Opleidingssector

\section{VMBO}

Naar leerweg

Theoretisch

Gemengd

Kaderberoepsgericht

Basisberoepsgericht

Naar sector

Landbouw

Techniek

Economie

Gezondheidszorg

BOL

BOL niveau 1

BOL niveau 2

Landbouw

Techniek

Economie

Gezondheidszorg

BOL niveau 3

Landbouw

Techniek

Economie

Gezondheidszorg

Gedrag en maatschappij

BOL niveau 4

Landbouw

Techniek

Economie

Gezondheidszorg

Gedrag en maatschappij

BBL

BBL niveau 1

BBL niveau 2

Landbouw

Techniek

Economie

Gezondheidszorg

BBL niveau 3

Landbouw

50

Techniek

Economie

Gezondheidszorg

Gedrag en maatschappij 
Tabel A9.8

Percentage werkende schoolverlaters waarvan huidige functie goede carrièremogelijkheden biedt Opleidingssector

BBL niveau 4

Landbouw

Techniek

59

Economie

Gezondheidszorg

Gedrag en maatschappij

HBO

Landbouw

Onderwijs

Techniek

Economie

Gezondheidszorg

Gedrag en maatschappij

Totaal

- = te weinig waarnemingen

Bron: ROA (SIS)

\section{Toelichting}

Vraag in de enquête:

Biedt uw functie goede carrièremogelijkheden? ( 1 'nauwelijks' tot en met 5 'heel veel'). Vermeld is het percentage van antwoordcategorie 4 en 5. 
Tabel A10.1

Opleiding achteraf opnieuw kiezen: intrede op de arbeidsmarkt

$\begin{array}{lr}\text { Opleidingssector } & \text { zelfde opleidin } \\ \text { HAVO/NWO } & 95 \\ \text { HAVO } & \\ \text { VWO } & \\ \text { VMBO } & \\ \text { Naar leerweg } & \\ \text { Theoretisch } & \\ \text { Gemengd } & \\ \text { Kaderberoepsgericht } & 81 \\ \text { Basisberoepsgericht } & 74\end{array}$

andere opleiding

$\%$

$\begin{array}{ll}95 & \mathbf{5} \\ 95 & 5 \\ 94 & 6\end{array}$

Naar sector

Naar sector
Landbouw
Techniek
Economie
Gezondheidszorg

$79 \quad 21$

22

$80-20$

$81-19$

$83 \quad 17$

$74 \quad 26$

MBO 28

BOL

81

BOL niveau 1

76

24

BOL niveau 2

75

Landbouw

Techniek

Economie

Gezondheidszorg

$\begin{array}{ll}82 & 17 \\ 88 & 18 \\ 64 & 12 \\ 71 & 36 \\ & 29\end{array}$

$\begin{array}{lll}\text { BOL niveau 3 } & \mathbf{8 1} & \mathbf{1 9} \\ \text { Landbouw } & 77 & 23 \\ \text { Economie } & 76 & 24 \\ \text { Gezondheidszorg } & 81 & 19 \\ \text { Gedrag en maatschappij } & 87 & 13\end{array}$

\begin{tabular}{|c|c|c|}
\hline BoL niveau 4 & 83 & 17 \\
\hline Landbouw & 78 & 22 \\
\hline Techniek & 85 & 15 \\
\hline Economie & 77 & 23 \\
\hline Gezondheidszorg & 85 & 15 \\
\hline Gedrag en maatschappij & 89 & 11 \\
\hline BBL & 86 & 14 \\
\hline BBL niveau 1 & 88 & 12 \\
\hline BBL niveau 2 & 86 & 14 \\
\hline Landbouw & 85 & 15 \\
\hline Techniek & 90 & 10 \\
\hline Economie & 72 & 28 \\
\hline Gezondheidszorg & 89 & 11 \\
\hline BBL niveau 3 & 85 & 15 \\
\hline Landbouw & 79 & 21 \\
\hline Techniek & 83 & 17 \\
\hline Economie & 75 & 25 \\
\hline Gezondheidszorg & 91 & 9 \\
\hline Gedrag en maatschappij & 92 & 8 \\
\hline
\end{tabular}


Tabel A10.1

Opleiding achteraf opnieuw kiezen: intrede op de arbeidsmarkt

$\begin{array}{lrr}\text { Opleidingssector } & \text { zelfde opleiding } & \text { andere opleiding } \\ \text { BBL niveau 4 } & \% & \mathbf{1 4} \\ \text { Techniek } & \mathbf{8 6} & 15 \\ \text { Economie } & 85 & 22 \\ \text { Gezondheidszorg } & 78 & 12 \\ \text { Gedrag en maatschappij } & 88 & 6 \\ \text { HBO } & 94 & \mathbf{2 0} \\ \text { Landbouw } & & 19 \\ \text { Onderwijs } & \mathbf{8 0} & 12 \\ \text { Techniek } & 81 & 16 \\ \text { Economie } & 88 & 29 \\ \text { Gezondheidszorg } & 84 & 14 \\ \text { Gedrag en maatschappij } & 71 & 21 \\ \text { Taal en cultuur } & 86 & 15\end{array}$

W0

$87-13$

Landbouw

Techniek

Economie

Gezondheidszorg

Gedrag en maatschappij

Taal en cultuur

Recht en openbare orde

Natuurwetenschappen

Bron: ROA (SIS); VSNU/IVA, 2009 
Tabel A11.1

Aantallen en respons

benaderde aantallen responspercentage ongewogen aantallen ${ }^{1)}$ gewogen aantallen

\begin{tabular}{|c|c|c|c|c|}
\hline HAVO/VWO & 5.173 & 37 & 1.896 & 73.763 \\
\hline HAVO & 2.881 & 34 & 975 & 41.359 \\
\hline VW0 & 2.292 & 40 & 921 & 32.404 \\
\hline VMBO & 10.301 & 28 & 2.791 & 89.898 \\
\hline \multicolumn{5}{|l|}{ Naar leerweg } \\
\hline Theoretisch & 3.340 & 30 & 991 & 38.643 \\
\hline Gemengd & 749 & 34 & 252 & 5.689 \\
\hline Kaderberoepsgericht & 3.035 & 28 & 848 & 24.035 \\
\hline Basisberoepsgericht & 3.177 & 22 & 700 & 21.530 \\
\hline \multicolumn{5}{|l|}{ Naar sector } \\
\hline Landbouw & 2.434 & 28 & 683 & 7.315 \\
\hline Techniek & 1.293 & 19 & 246 & 14.137 \\
\hline Economie & 1.642 & 25 & 395 & 11.649 \\
\hline Gezondheidszorg & 1.592 & 31 & 476 & 18.153 \\
\hline MBO & 26.509 & 19 & 5116 & 133.437 \\
\hline BOL & 19.150 & 20 & 3880 & 83.030 \\
\hline BOL niveau 1 & 862 & 12 & 105 & 5.807 \\
\hline Landbouw & 35 & 17 & 6 & 90 \\
\hline Techniek & 119 & 13 & 15 & 835 \\
\hline Economie & 631 & 12 & 75 & 4.323 \\
\hline Gezondheidszorg & 77 & 12 & 9 & 559 \\
\hline BOL niveau 2 & 3.705 & 15 & 557 & 19.162 \\
\hline Landbouw & 293 & 22 & 65 & 1.279 \\
\hline Techniek & 907 & 13 & 117 & 4.714 \\
\hline Economie & 1.460 & 14 & 206 & 7.501 \\
\hline Gezondheidszorg & 1.044 & 16 & 169 & 5.668 \\
\hline BOL niveau 3 & 3.923 & 19 & 758 & 17.226 \\
\hline Landbouw & 458 & 22 & 100 & 1.413 \\
\hline Techniek & 275 & 11 & 31 & 630 \\
\hline Economie & 1.217 & 16 & 189 & 5.742 \\
\hline Gezondheidszorg & 841 & 25 & 208 & 4.461 \\
\hline Gedrag en maatschappij & 1.132 & 20 & 230 & 4.980 \\
\hline BOL niveau 4 & 10.660 & 23 & 2460 & 40.836 \\
\hline Landbouw & 787 & 29 & 225 & 2.598 \\
\hline Techniek & 3.577 & 22 & 769 & 9.316 \\
\hline Economie & 3.293 & 21 & 680 & 12.480 \\
\hline Gezondheidszorg & 1.187 & 28 & 329 & 7.009 \\
\hline Gedrag en maatschappij & 1.816 & 25 & 457 & 9.432 \\
\hline BBL & 7.359 & 17 & 1236 & 50.407 \\
\hline BBL niveau 1 & 764 & 13 & 51 & 1.932 \\
\hline Landbouw & 412 & 13 & 20 & 1.480 \\
\hline Techniek & 160 & 13 & 20 & 1.247 \\
\hline Economie & 168 & 12 & 4 & 241 \\
\hline Gezondheidszorg & 24 & 17 & 95 & 4.900 \\
\hline BBL niveau 2 & 2.702 & 15 & 406 & 21.346 \\
\hline Landbouw & 376 & 13 & 50 & 1.612 \\
\hline Techniek & 1.374 & 14 & 194 & 11.943 \\
\hline Economie & 667 & 15 & 100 & 4.610 \\
\hline Gezondheidszorg & 285 & 22 & 62 & 3.181 \\
\hline
\end{tabular}


Tabel A11.1

Aantallen en respons

Opleidingssector benaderde aantallen responspercentage ongewogen aantallen" gewogen aantallen

\begin{tabular}{|c|c|c|c|c|}
\hline BBL niveau 3 & 2.681 & 18 & 478 & 15.780 \\
\hline Landbouw & 308 & 16 & 48 & 968 \\
\hline Techniek & 1.160 & 16 & 185 & 6.988 \\
\hline Economie & 516 & 16 & 82 & 2.334 \\
\hline Gezondheidszorg & 559 & 23 & 131 & 4.412 \\
\hline Gedrag en maatschappij & 138 & 23 & 32 & 1.077 \\
\hline BBL niveau 4 & 1.212 & 21 & 257 & 8.380 \\
\hline Landbouw & 88 & 31 & 27 & 591 \\
\hline Techniek & 274 & 16 & 44 & 1.540 \\
\hline Economie & 336 & 16 & 54 & 1.838 \\
\hline Gezondheidszorg & 295 & 29 & 87 & 2.908 \\
\hline Gedrag en maatschappij & 216 & 21 & 44 & 1.471 \\
\hline HBO & 39.839 & 37 & 13.614 & 49.550 \\
\hline Landbouw & 1.147 & 43 & 466 & 2.439 \\
\hline Onderwijs & 4.409 & 36 & 1.486 & 6.522 \\
\hline Techniek & 6.921 & 37 & 2.387 & 8.442 \\
\hline Economie & 15.520 & 35 & 5.030 & 19.030 \\
\hline Gezondheidszorg & 3.885 & 41 & 1.522 & 4.050 \\
\hline Gedrag en maatschappij & 4.977 & 37 & 1.769 & 5.942 \\
\hline Taal en cultuur & 2.980 & 35 & 954 & 3.125 \\
\hline Totaal & 81.822 & 30 & 23.417 & 346.648 \\
\hline
\end{tabular}

Bron: ROA (SIS)

${ }^{1)}$ het aantal ingevulde vragenlijsten dat in het onderzoeksbestand is opgenomen. 
